8 od FACULDADE DE FILOSOFIA, CIÊNCIAS Ë LE LETRAS DE RIBEIRÃO PRETO PROGRAMA DE PÓS-GRADUACCÃO EM BIOLOGIA COMPARADA
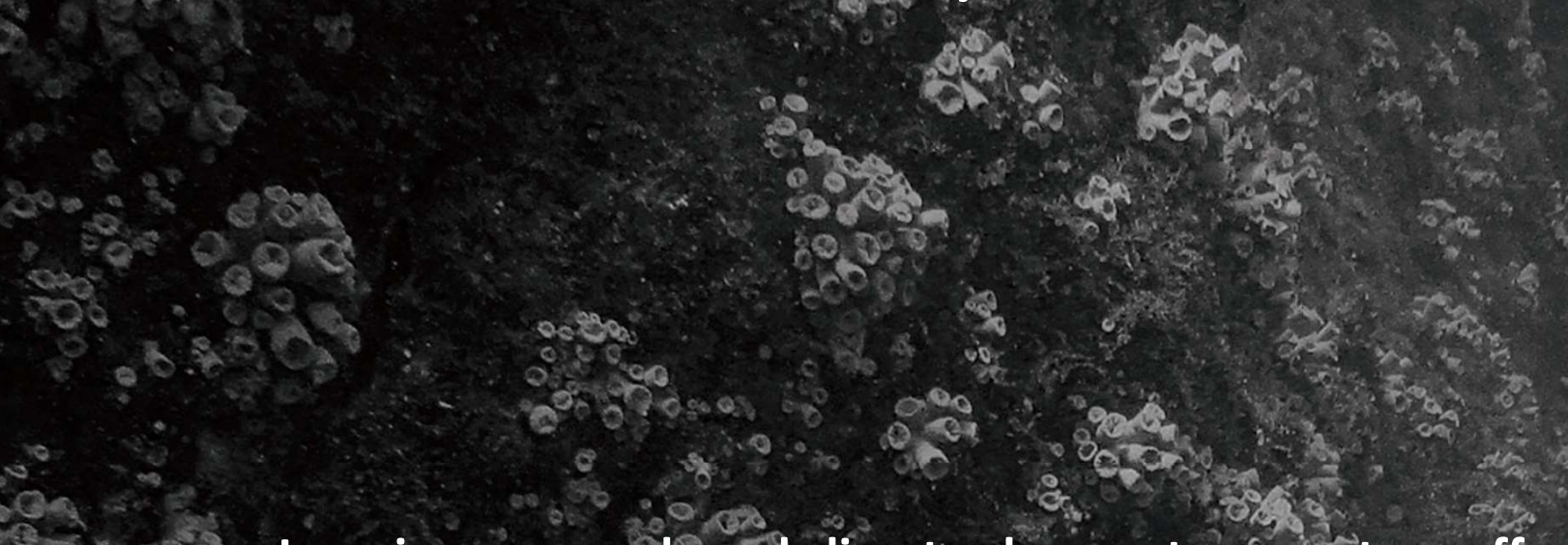

83 Invasive sun corals and climate change: temperature effects on pelagic dispersal potential and interspecific competition 80 : of

O invasor coral sol e mudanças climáticas: efeitos da temperatura - na dispersão pelágica e competição interespecifica

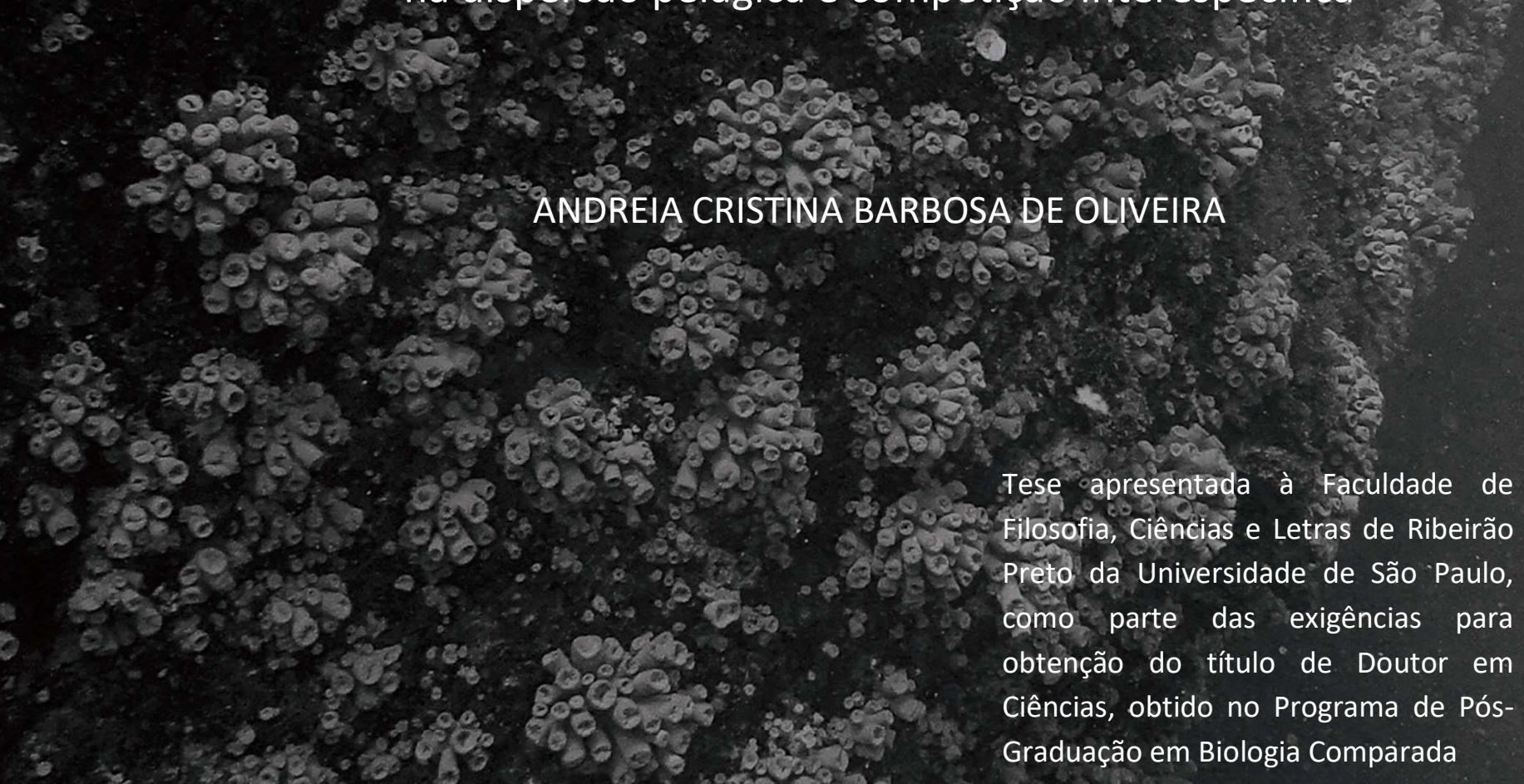


FACULDADE DE FILOSOFIA, CIÊNCIAS E LETRAS DE RIBEIRÃO PRETO PROGRAMA DE PÓS-GRADUAÇÃO EM BIOLOGIA COMPARADA

\title{
Invasive sun corals and climate change: temperature effects on pelagic dispersal potential and interspecific competition
}

O invasor coral sol e mudanças climáticas: efeitos da temperatura na dispersão pelágica e competição interespecífica

ANDREIA CRISTINA BARBOSA DE OLIVEIRA

Orientador: Prof. Dr. Augusto Alberto Valero Flores

Co-orientadora: Profa. Dra. Catarina Vinagre

\begin{abstract}
Tese apresentada à Faculdade de Filosofia, Ciências e Letras de Ribeirão Preto da Universidade de São Paulo, como parte das exigências para obtenção do título de Doutor em Ciências, obtido no Programa de PósGraduação em Biologia Comparada.
\end{abstract}

Ribeirão Preto - SP 
Autorizamos a reprodução e divulgação total ou parcial deste trabalho, por qualquer meio convencional ou eletrônico, para fins de estudo e pesquisa, desde que citada a fonte.

Barbosa, Andreia Cristina Câmara

O invasor coral sol e mudanças climáticas: efeitos da temperatura na dispersão pelágica e competição interespecífica

$100 \mathrm{pp}$.

Tese apresentada à Faculdade de Filosofia, Ciências e Letras de Ribeirão Preto da USP, como parte das exigências para a obtenção do título de Doutor em Ciências, Área: Biologia Comparada.

Orientador: Flores, Augusto Alberto Valero

Co-orientadora: Vinagre, Catarina

1. Invasões biológicas. 2. Competição interespecífica. 3. Tubastraea. 4. Mudanças climáticas. 5. Potencial de dispersão.

6. Coral sol 
NOME: Andreia Cristina Barbosa de Oliveira

TÍTULO: O invasor coral sol e mudanças climáticas: efeitos da temperatura na dispersão pelágica e competição interespecífica

Tese apresentada à Faculdade de Filosofia, Ciências e Letras de Ribeirão Preto, Universidade de São Paulo, para obtenção do título de Doutor em Biologia Comparada.

Aprovado em:

Banca Examinadora

Membro:

Julgamento:

Membro:

Julgamento:

Membro:

Julgamento:

Membro:

Julgamento:

Membro:

Julgamento:
Instituição:

Assinatura:

Instituição:

Assinatura:

Instituição:

Assinatura:

Instituição:

Assinatura:

Instituição:

Assinatura: 


\section{AGRADECIMENTOS}

Agradeço ao meu orientador Prof. Dr. Augusto Alberto Valero Flores, por novamente confiar no meu trabalho, pela sua dedicação, atenção, incansável paciência e especialmente pelos nossos bons e divertidos momentos nessa relação que, ao longo dos anos, evoluiu de orientador $x$ aluna para uma boa amizade. À Prof. Dra. Catarina Vinagre, minha co-orientadora, principal responsável pela ideia inicial desse trabalho e que apesar de longe, sempre se manteve presente.

Ao CNPq pelo financiamento desse projeto através do programa do Ciência sem fronteiras 'Pesquisador visitante especial' concedido à Prof. Dra. Catarina Vinagre (Processo \#400614/2014-6). Ao Programa de Pós-graduação em Biologia Comparada da FFCLRP-USP pela da bolsa de doutorado através das 'Cotas do Programa de pós-graduação' concedida pelo CNPq (Processo \#159822/2015-7).

Ao Dr. Damián Mizrahi pelo design do experimento de laboratório, ajuda em saídas de campo e revisão de manuscritos. Ao Prof. Dr. Marcelo V. Kitahara, agradeço as inúmeras dicas e horas de mergulho. Ao Dr. Rafael Campos Duarte (Mogli) pela ajuda nas análises estatísticas. Ao Dr. Juan Pablo Quimbayo pelo apoio e energia positiva. A todas as Cebimarianas: Bruna, Karine, Carla K., Carla P., Camila O., Camila B., Aline, Laiza, Raquel, Estela, Cláudia, Juliana, Kátia, Ariely, Isabela e Leilane, que em algum momento se envolveram nesse trabalho, seja com palpites, companhia e ajuda no campo, ou com boas risadas nos momentos de descontração.

Aos funcionários do Centro de Biologia Marinha da USP (CEBIMar-USP), que direta ou indiretamente tornaram possível a realização desse trabalho. Ao Sr. José, por tornar nossos dias no CEBIMar mais saborosos. Aos funcionários da manutenção, Fábio e Elias pela ajuda na montagem e manutenção de toda a parte elétrica do experimento de laboratório. 
Ao Jerônimo, sempre alegre e pronto para ajudar no que fosse necessário com toda a prontidão. À Silvia, responsável pela limpeza da sala de estudos e dos laboratórios, sem esquecer, é claro, de seus brigadeiros irresistíveis. Especialmente aos técnicos Eduardo e Joseilto pela companhia nos mergulhos, lanchinhos mais que especiais, e por sempre estarem dispostos a me conduzir nas inúmeras idas e vindas até a llha de Búzios.

A minha família pelo apoio, compreensão e incentivo sempre. Especialmente aos sobrinhos mais lindos do mundo: Pedro, Isabela, Magnólia e Sarah Lua, amo vocês!

Ao meu amor, Fernando, que encarou uma mudança radical deixando família, amigos e estabilidade, para me permitir realizar esse sonho. Sem seu apoio eu certamente não estaria aqui hoje! 
RESUMO

Atualmente, invasões biológicas e mudanças climáticas são consideradas as mais importantes ameaças à biodiversidade marinha. Os corais sol, Tubastraea tagusensis e $T$. coccinea, são espécies invasores que colonizaram habitats recifais costeiros da Flórida até o Sul do Brasil, impactando negativamente comunidades costeiras. Apesar de ser foco de diversos estudos, até o momento não há informação de como os corais sol responderão ao aquecimento dos oceanos provocado pelas mudanças climáticas. Para melhor compreensão dos mecanismos envolvidos na dinâmica da invasão na região e também prever suas possibilidades em um cenário futuro de aquecimento investigou-se: (i) padrões de distribuição espécie-específica desde grandes escalas entre localidades (dezenas de km) até pequenas escalas dentro de localidades $(10 \times 10 \mathrm{~cm})$, além de sua distribuição de acordo com um fator ambiental chave (profundidade), como uma aproximação de preferencias térmicas; (ii) efeitos da temperatura na performance de colônias adultas em contato com um competidor nativo; (iii) efeitos da temperatura na taxa de mortalidade, assentamento e potencial de dispersão de propágulos de coral sol. Nossos resultados mostraram segregação de espécies entre localidades e tendências de distribuição espécieespecífica em diferentes profundidades, sugerindo possíveis preferências térmicas. A menores escalas, em locais com considerável co-ocorrência das espécies, foi observado um provável caso de coexistência neutra, onde a presença das duas espécies é independente. Quando em contato com uma espécie endêmica, o coral cérebro, T. tagusensis mostrou superioridade competitiva, provocando danos teciduais e redução de crescimento no coral nativo, sem demonstrar sinais de performance reduzida, independente de temperatura ou sazonalidade. Os propágulos de coral sol apresentaram impressionante plasticidade, o que provavelmente afeta o seu tempo em ambiente pelágico e potencial de dispersão devido a 
uma eventual janela de competência secundária, regulada por temperatura, o que permite uma resposta de escape de ambientes com altas temperaturas, onde as taxas de mortalidade são altas. De forma geral, esse trabalho apresentou um cenário preocupante, uma vez que a performance dos corais sol será dificilmente afetada pelas mudanças climáticas. Aquecimento dos oceanos em regiões temperadas podem promover aumento da área invadida para regiões subtropicais e temperadas onde as condições de temperatura e condições para sobrevivência de propágulos e assentamento são melhores.

Palavras chave: invasões biológicas; mudanças climáticas; coral sol; Tubastraea; competição interespecífica; potencial de dispersão. 
ABSTRACT

At present days, biological invasions and climate change are considered the most important threats to marine biodiversity. Invasive sun corals Tubastraea tagusensis and T. coccinea have successfully colonized coastal reef habitats from Florida to Southern Brazil, negatively impacting native coastal assemblages. Despite being focus of several studies, there was so far no information on how sun corals might respond to ocean warming due to climate change. To better understand mechanisms underlying the invasion dynamics in the region and also foresee its possible pathways in a future warmer scenario we investigated: (i) species-specific distribution patterns from large scales across locations (tens of $\mathrm{km}$ ) to small scales within locations $(10 \times 10 \mathrm{~cm})$, and their distribution according to a key environmental filter (depth) considered a proxy of thermal preferences; (ii) the effects of temperature on the performance of adult sun corals colonies towards a native competitor; (iii) temperature effects on sun corals propagule mortality rates, settlement rates and dispersal potential. Our results show species segregation across locations, and species-specific depth distributions trends, suggesting possible thermal preferences. At small patches with considerable species co-occurrence, we observed a possible case of neutral coexistence, where both species presence can be modeled as independent events. When in contact with the endemic brain coral, $T$. tagusensis has shown to be a better competitor, imposing tissue damage and reduced growth to the native coral, exhibiting no sign of reduced performance regardless temperature or season. Sun corals propagules presented an outstanding plasticity, likely to affect their pelagic duration and dispersal potential, due to an eventual temperature-regulated secondary competence window, allowing an escape response from high temperature habitats where larval mortality rates are high. Overall, this work presented a worrying future scenario, since sun corals performance will hardly be affected 
by climate change. Ocean warming of temperate regions may promote range extensions to subtropical and warm-temperate areas where temperature conditions for propagule survival and settlement success are best.

Key words: biological invasions; climate change; sun coral; Tubastraea; interspecific competition; dispersal potential. 


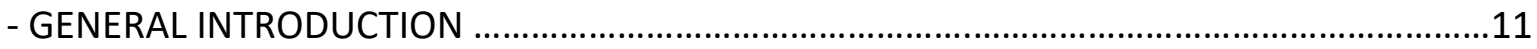

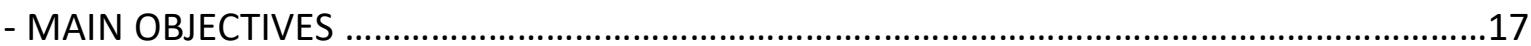

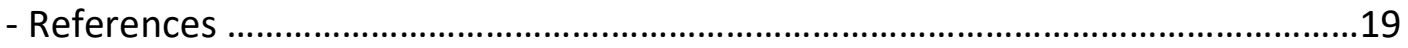

- Chapter 1: INVASIVE SUN CORALS DISTRIBUTION ON SOUTHWESTERN ALTANTIC: A

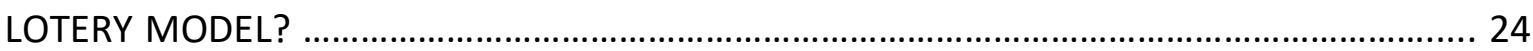

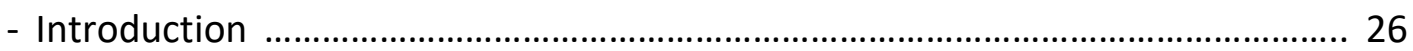

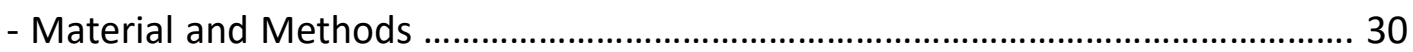

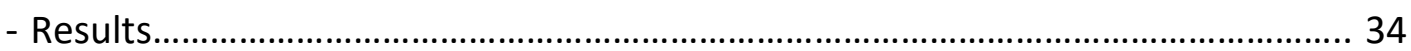

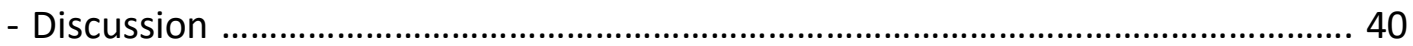

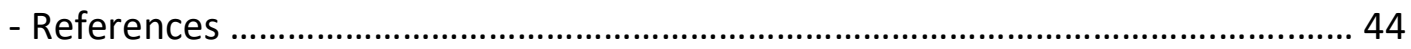

- Chapter 2: INVASIVE SUN CORALS AND WARMING POSE INDEPENDENT THREATS TO THE BRAIN CORAL MUSSISMILIA HISPIDA IN THE SOUTHWESTERN ATLANTIC ......................... 49

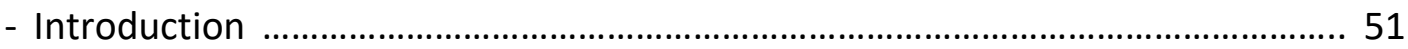

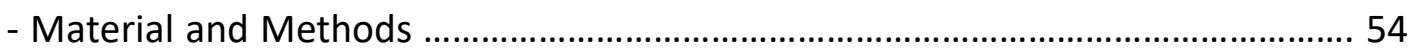

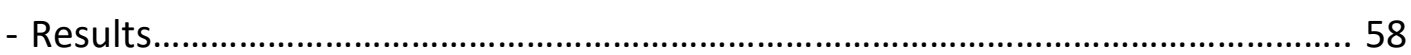

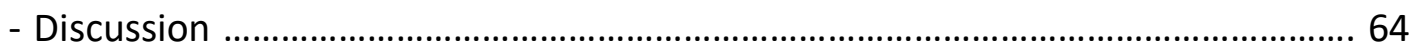

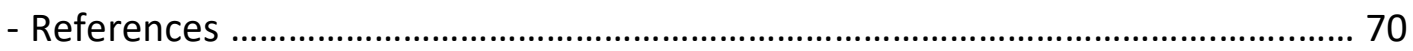

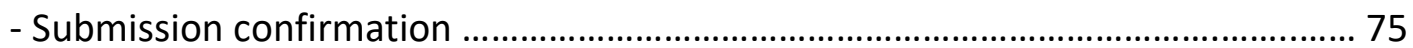

- Chapter 3: TEMPERATURE-DRIVEN SECONDARY COMPETENCE WINDOWS MAY INCREASE THE DISPERSAL POTENTIAL OF INVASIVE SUN CORALS........................................................ 76

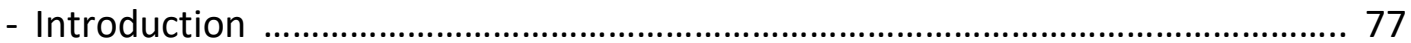

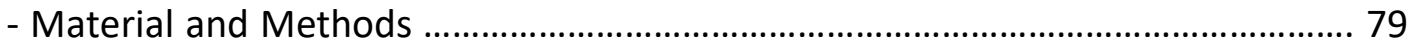

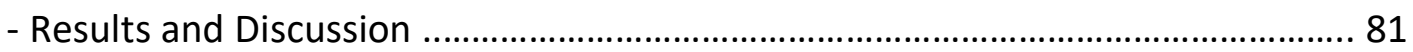

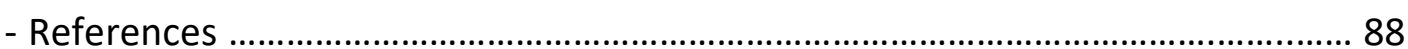

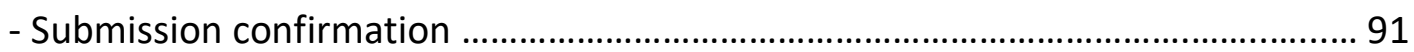

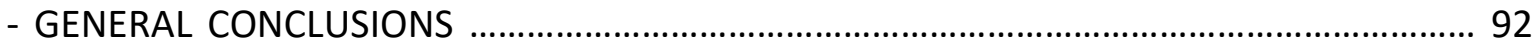

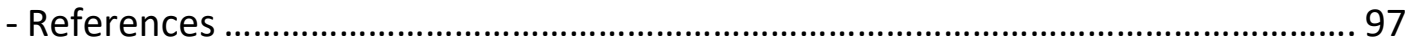




\section{GENERAL INTRODUCTION}

The occurrence of human-facilitated biological invasions is rapidly growing in marine coastal regions of the world (e.g. Carlton 1989, 1996, Ruiz et al. 2000). This is mostly a consequence of the increasing transoceanic commercial transport along the past few decades, which accidentally carries a large number of species in ballast water and sediments or fouling ship hulls and oil and gas platforms (Carlton \& Geller 1993, Bax et al. 2003, Fenner \& Banks 2004). These vectors transport yearly thousands of bacteria, viruses, protists, plants and marine animals, within and between oceans, often surpassing several natural barriers (Carlton 1996, Ruiz et al. 1997). The introduction of exotic species, intentional or accidental, is considered a threat to marine biodiversity (Carlton \& Geller 1993, Lages et al. 2006, Kersting et al. 2015), and has received much attention in the recent decades due to their potentially severe ecological and economic impacts in the receiving environments (Ricciardi \& Rasmussen 1998, Bax et al. 2003, Bohn et al. 2013)

While many exotic species become part of local communities, others are invasive, rapidly reach high densities and end up becoming dominant (Bax et al. 2003, de Paula \& Creed 2004). Biological invaders can affect native species and communities through competition for different resources, like nutrients, light and especially space (Lages et al. 2010). Negative relationships between exotic and native species may yet include predation, parasitism and exclusion through allelopathic interactions (Lages et al. 2012), which can promote changes in the invaded community structure and ecosystem function (Ferreira et al. 2004, Lages et al. 2006, 2011, Kersting et al. 2015), reducing species richness and causing local extinction (Carlton 1996, Ruiz et al. 1997, Sax \& Gaines 2003). Therefore, biological invasions can have many direct and indirect effects on marine ecosystems, from altering 
trophic structure and nutrient dynamics (Carlton 1996, Ruiz et al. 1997, Silva et al. 2019), to reducing biodiversity (Ruiz et al. 1997, Silva et al. 2019).

Sun corals, Tubastraea spp., have been recognized as invasive species in the southwestern Atlantic Ocean (e.g. Ferreira 2003, Fenner \& Banks 2004, Paula \& Creed 2004). Tubastraea coccinea Lesson, 1829 was first described from Bora Bora Island, French Polynesia, with a natural range throughout the Indo-Pacific. Invasive to the Caribbean Sea, Gulf of Mexico and Southwestern Atlantic (Fenner \& Banks 2004, Creed et al. 2016) the species is currently considered cosmopolitan. Its congener Tubastraea tagusensis Wells, 1982 was first described from the Galapagos Archipelago, Ecuador, and is invasive to the Brazilian coast (da Silva et al. 2014, Creed et al. 2016). Sun corals were first reported in Southeast Brazil in the late 80 's, colonizing oil and gas platforms in the Campos Basin (Castro \& Pires 2001). More recently they have expanded to numerous sites along the Brazilian coast, spanning the states of Ceará (Soares et al. 2018), Bahia (Sampaio et al. 2012), Rio de Janeiro (de Paula \& Creed 2005, da Silva et al. 2014), São Paulo (Mantelatto et al. 2011) and Santa Catarina (Lopes 2009).

The "invasive" status of sun corals Tubastraea spp. (Global Invasive Species Database, www.invasivespecies.net) is largely due to their high growth rates (Vermeij 2006), early maturation (Glynn et al. 2008) and their ability to reproduce sexually and asexually (Campbell 1983), being the latter dominant in southwestern Atlantic populations (Capel et al 2017). Sun corals planula larvae can metamorphose into planktonic polyps in the water column, increasing their dispersal potential (Mizrahi et al. 2014a) and under stressful conditions recently settled polyps are able to bail-out and re-settle into more suitable habitats (Capel et al. 2014). Sun corals also have high regeneration capacity, in which new polyps can be formed from small tissue fragments (Luz et al. 2018). They are 
also successful competitors, since they can cause tissue necrosis and partial mortality on native corals (Creed 2006, Santos et al. 2013) and zoanthids (Luz \& Kitahara 2017), and have the capacity to inhibit recruitment of other species through negative allelopathic interactions (Lages et al. 2006, 2011, Mizrahi et al. 2017). Additionally, as azooxanthellate corals (i.e. they do not contain symbiotic alga) they are not light-limited, can stand drastic environmental change (Lenz et al. 2011) and lack any known natural predators in the Southwest Atlantic (Lages et al. 2010, Moreira \& Creed 2012). All these characteristics combined may have contributed to the current dominance of sun-corals at sites where first colonization was recent.

The biological interactions of sun corals with pre-established assemblages may reduce reef biodiversity and change the ecosystem (Riul et al. 2013). Besides the exclusion of several fouling species (Mizrahi et al. 2017), sun corals reengineer reef space also affecting mobile invertebrate assemblages in invaded habitats (Silva et al. 2019). At some sites from northern São Paulo to southern Rio de Janeiro states, sun-corals almost saturate space at patches of a size ranging from several tens to a few hundred meters long, especially on vertical walls, where both species are commonly found intermingled (e.g. Creed 2006, Creed \& Paula 2007, Lages et al. 2011, 2012, Mizrahi et al. 2014b) (Fig. 1). 


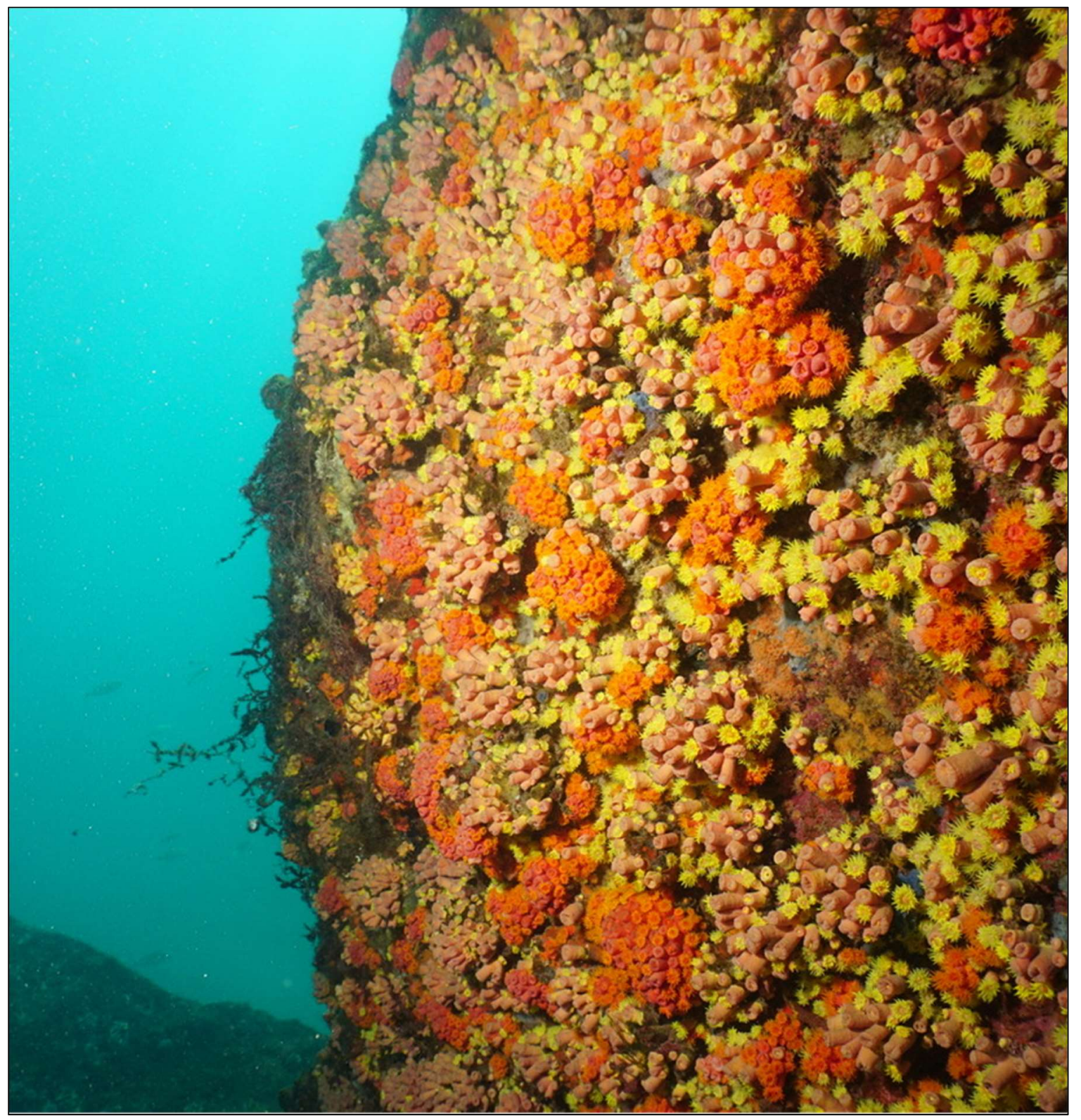

Figure 1. Sun corals Tubastraea coccinea (orange) and T. tagusensis (yellow) at Buzios Island, covering close to $100 \%$ of vertical hard substrate. Photo credits: Marcelo V. Kitahara. 
Several authors have been warning to the sun corals' potential of becoming the benthic dominant organism in Brazilian coastal rocky reefs (e.g. Creed \& Paula 2007, Lages et al. 2011, Creed 2017). Creed (2006) described the sun corals deleterious effect on the native brain coral Mussismilia hispida the most abundant scleractinian, endemic to Brazilian shallow waters (Oigman-Pszczol et al. 2004). The contact with the invasive species results in M. hispida tissue necrosis, an evident indicator of the competitive superiority of sun corals, that can reduce $M$. hispida abundance, and possibly lead the native species to extinction (Riul et al. 2013). The brain coral M. hispida is not only one of the most important Brazilian native scleractinians (Oigman-Pszczol et al. 2004), but also a habitat constructor host for more than 130 different invertebrates (Nogueira 2003). Sun corals can also outcompete Palythoa caribaeorum the dominant zoantharian in Brazilian coastal waters, another important community structuring species on rocky reefs (Luz \& Kitahara 2017).

There are very few records of Tubastraea spp. being impaired by competitors, for instance they can be overgrown by sponges (Lages et al. 2012), they can possibly be removed by nesting pomacentrid fishes (Mizrahi et al. 2016) and their larvae suffer negative allelopathic effects from the also non-indigenous snowflake coral, Carijoa riisei (Mizrahi et al. 2017). On the other hand, the invasive species also present alternative growth strategies, avoiding suffocation by fast growth sponges (Vermeij 2005), which increases colonies survival capacity towards space competition with other benthic organisms. Lages et al. (2010) demonstrated that sun corals extracts contain chemical substances effective not only against predators, but also in reducing fouling organisms' settling rates. Actually, these substances can also inhibit the settlement of conspecific planula larvae, directing their settlement to areas free of chemical mediation, far from 
adult colonies and thus favoring their establishment in new, still unoccupied areas (Mizrahi et al. 2017), increasing thus their invasive potential.

The invasive potential of marine species is vastly associated to their efficiency in reproduction, propagule dispersion and successful recruitment (Carlton 1996). Invertebrate dispersal potential is partly regulated by their propagule characteristics, such as buoyancy, swimming ability, the amount of time they spend in the water column, their quality and how long they are competent (i.e. able to successfully settle; Pechenik 1990, Harii et al. 2002, 2007). Larval duration, settlement behavior and survival rates are strongly regulated by environmental factors, being temperature the most important one (Thorson 1950, O'Connor et al. 2007, Nozawa \& Harrison 2007). Higher temperatures tend to increase larval metabolic rates, shortening the planktonic phase (Thorson 1950, O'Connor et al. 2007), and increasing mortality rates (Bassim \& Sammarco 2003, Serrano et al. 2018). In adult coral colonies, higher temperatures can cause a potentially severe reduction of reproductive success (Bassim \& Sammarco 2003, Randall \& Szmant 2009a, 2009b), reduced growth rates (Cantin et al. 2010) and bleaching (Leão et al. 2008, Coles \& Riegl 2013, Dias \& Gondim 2016)

Currently, there is a growing demand for precise forecasting of climate change effects, and how they will affect biological diversity and ecosystems functioning (Botkin et al. 2007). There is no prediction on Brazilian coastal waters warming, although the Brazilian Panel on Climate Change (PBMC) disclosed a predicted increase of $6^{\circ} \mathrm{C}$ on air temperature until 2100 to Southeast region (PBMC 2012), which will certainly impact on coastal waters temperature. Despite being the focus on many recent studies, there is few information on how the sun corals will respond to the temperature increase due to global warming. At present days, climate change and invasive species are two of the most widespread global 
stressors (Rahel \& Olden 2008, Kersting et al. 2015). Thus, it is of increasing importance to investigate the response of organisms to ocean warming, particularly invasive species, capable of potentially alter ecosystem dynamics and threaten native biodiversity and balance.

\section{MAIN OBJECTIVES}

The central objective of this work was the assessment of the responses of sun corals to climate change and its consequences to native communities. Understanding the invasive species responses to alternative climate scenarios is very important, as long it will support any predictions on how stable will sun coral populations be in its current invasive range, as well as anticipating any range expansion. To do so, this work was divided into three main objectives (three chapters), approaching different processes related to the sun corals and their invasion.

\section{$\underline{\text { Sun corals distribution, abundance and depth patterns }}$}

Knowledge on the interspecific association between both sun coral species, Tubastraea tagusensis and T. coccinea, at different spatial scales would allow a better understanding of the ecological processes involved in their distribution. Positive associations would suggest niche similarities and resource sharing, while negative associations would indicate interspecific competition and spatial segregation. Some features of the two sun corals suggest depth distribution preferences. Native from the warm Indo-pacific, T. coccinea has orange tentacles and shorter corallites, exhibiting a large (thus strong) coral-substrate attachment area, while $T$. tagusensis, original from the cooler Galapagos Islands, has yellow tentacles and elongated corallites (Mantelatto 2012). Corals 
depth distribution can be regulated by turbulence and temperature regimes (Sheppard 1982, Kahng et al. 2012). This way we hypothesized the existence of species-specific vertical distribution patterns, where $T$. coccinea would be more abundant at shallow warmer and more turbulent waters. Therefore, the first chapter targeted mapping and quantifying the abundance of both sun corals in the northern coast off São Paulo state, Brazil. At local scales, we verified if depth distributions are compatible to thermal niche and morphologybased predictions and whether species associations support niche related or stochastic processes.

Invasive coral vs native coral interactions

The outcomes of species interactions in a notably non-equilibrium state environment, such as the target invaded region, under alternative climate scenarios is very important. This information will support future forecasting on how dense will sun coral populations be along the present invasive range, and also help anticipating range shifts in a warmer future. We examined competitive interactions between the sun coral Tubastraea tagusensis and the brain coral Mussismilia hispida, at a range of temperature conditions. The second chapter involves field experiments to examine the interactions between these corals, during summer and winter, testing seasonal tendencies for the outcome of coralcoral interactions. The approach was extended to the laboratory to obtain evidence of interactions at present-day thermal conditions and at far-ranging extremes, hot and cold, expected by 2100 (PBMC 2012). 


\section{Sun coral larval dispersal potential}

Populational stability in corals depends on larval dispersal to suitable reef habitats, where new colonies will be founded. Thus, larval features that directly affect dispersal potential may determine the long-term persistence of the sun coral in the invaded region. Temperature can impact larval behavior and regulate the amount of time larvae will spend in the water column before settling, thus altering their dispersal potential (Thorson 1950, O'Connor et al. 2007, Nozawa \& Harrison 2007). This issue was approached in the third chapter, through laboratory experiments, where sun coral larvae were submitted to a range of temperature scenarios to obtain evidence of larval performance at present-day and future thermal conditions. Larval performance and dispersal potential were evaluated through survival rates, capacity to metamorphose into planktonic polyps and both larval and polyp settlement rates.

\section{REFERENCES}

Bassim KM, Sammarco PW (2003). Effects of temperature and ammonium on larval development and survivorship in a scleractinian coral (Diploria strigose). Marine Biology, 142: 241-252.

Bax N, Williamson A, Aguero M, Gonzalez E, Geeves W (2003). Marine Invasive Alien Species: A Threat to Global Diversity. Marine Policy, 27: 313-323.

Bohn K, Richardson CA, Jenkins SR (2013). The importance of larval supply, larval habitat selection and post-settlement mortality in determining intertidal adult abundance of the invasive gastropod Crepidula fornicate. J Exper Mar Biol Ecol, 440: 132-140.

Botnik DB, Saxe H, Araújo MB, Betts R, Bradshaw RHW, Cedhagen T, Chesson P, Dawson TP, Etterson JR, Faith DP, Ferrier S, Guisan A, Hansen AS, Hilbert DW, Loehle C, Margules C, New M, Sobel MJ, Stockwell DRB (2007). Forecasting the Effects of Global Warming on Biodiversity. BioScience, 57: 227-236.

Campbell RD (1983). Cnidaria Em Giese, AC e Pearse, JS (Eds): Reproduction of marine invertebrates I. Academic Press New York, 133-200.

Capel KCC, Migotto AE, Zilberberg C, Kitahara MV (2014). Another tool towards invasion? Polyp "bail-out" in Tubastraea coccinea. Coral Reefs 33, 1165.

Capel KCC, Toonen RJ, Rachid CTCC, Creed JC, Kitahara MV, Forsman Z, Zilberberg C. (2017). Clone wars: asexual reproduction dominates in the invasive range of Tubastraea spp. (Anthozoa: Scleractinia) in the South-Atlantic Ocean. PeerJ 5: e3873. 
Cantin NE, Cohen AL, Karnauskas, KB, Tarrant AM, McCorkle DM (2010). Ocean warming slows coral growth in the central red sea. Science, 329: 322.

Carlton JT (1989). Man's role in changing the face of the ocean: Biological invasions and implications for conservation of near-shore environments. Conservation Biology, 3:265-273.

Carlton JT, Geller JB (1993). Ecological roulette: The global transport and invasion of non-indigenous marine organisms. Science, 261: 78-82.

Carlton JT (1996). Pattern, process, and prediction in marine invasion ecology. Biological conservation, 78: 97-106.

Castro CB, Pires D (2001). Brazilian coral reefs: what we already know and what is still missing. Bulletin of Marine Science, 69: 357-371.

Coles SL, RiegI BM (2013). Thermal tolerances of reef corals in the Gulf: A review of the potential for increasing coral survival and adaptation to climate change through assisted translocation. Marine Pollution Bulletin, 72: 323-332.

Creed JC (2006). Two invasive alien azooxanthellate corals, Tubastraea coccinea and Tubastraea tagusensis, dominate the native zooxanthellate Mussismilia hispida in Brazil. Coral Reefs, 25: 350.

Creed JC, Paula AF (2007). Substratum preference during recruitment of two invasive recruitment of two invasive alien corals onto shallow-subtidal tropical rocky shores. Mar Ecol Progr Ser, 330: 101-111.

Creed JC, Fenner D, Sammarco PW, Cairns S, Capel KCC, Junqueira AOR, Cruz I, Miranda RJ, Carlos-Júnior LA, Mantelatto MC, Oigman-Pszczol SS (2016). The invasion of the azooxanthellate coral Tubastraea (Scleractinia: Dendrophylliidae) throughout the world: history, pathways and vectors. Biological Invasions, 19:283-305.

Da Silva AG, De Paula AF, Fleury BG, Creed JC (2014). Eleven years of range expansion of two invasive corals (Tubastraea coccinea and Tubastraea tagusensis) through the southwest Atlantic (Brazil). Estuarine, Coastal and Shelf Science 141: 9-16.

De Paula AF, Creed JC (2004). Two species of the coral Tubastraea (Cnidaria, Sclerectinia) in Brazil: a case of accidental introduction. Bulletin of Marine Science, 74: 175-183.

De Paula AF, Creed JC (2005). Spatial distribution and abundance of non-indigenous coral genus Tubastraea (Cnidaria, Scleractinia) around Ilha Grande, Brazil. Brazil Journal Biology, 65: 661-673.

Dias TLP, Gondim Al (2013). Bleaching in scleractinians, hydrocorals, and octocorals during thermal stress in a northeastern Brazilian reef. Mar Biodiv, 46: 303-307.

Fenner D, Banks K (2004). Orange cup coral Tubastraea coccinea invades Florida and the Flower Garden Banks, Northwestern Gulf of Mexico. Coral Reefs, 23: 505-507.

Ferreira CEL (2003). Non-indigenous corals at marginal sites. Coral Reefs, 22: 498.

Ferreira CEL, Gonçalvez JEA, Coutinho R (2004). Cascos de navios em plataformas como vetores na introdução de espécies exóticas. In: Salles Vianna da Silva, J. Corrêa de Souza, R.C (Orgs) Água de lastro e bioinvasão. Ed. Interciência, 143-155.

Glynn PW, Colley SB, Maté JL, Cortés J, Guzman HM, Bailey RL, Feingold JS, Enochs IC (2008). Reproductive ecology of the azooxanthellate coral Tubastraea coccinea in the Equatorial Eastern Pacific: Part V. Dentrophylliidae. Marine Biology, 153: 529-544.

Global Invasive Species Database - www.invasivespecies.net 
Harii S, Kayanne H, Takigawa H, Hayashibara T, Yamamoto M (2002). Larval survivorship, competency periods and settlement of two brooding corals, Heliopora coerulea and Pocillopora damicornis. Marine Biology, 141: 39-46.

Harii S, Nadaoka K, Yamamoto M, Iwao K (2007). Temporal changes in settlement, lipid content and lipid composition of larvae of the spawning hermatypic coral Acropora tenuis. Mar Ecol Progr Ser, 346: 8996.

Kahng S, Wagner D, Lantz C, Vetter O, Gove J, Merrifield M (2012) Temperature related depth limits of warmwater corals. Proceedings of the 12th International Coral Reef Symposium, Ecology of mesophotic coral reefs.

Kersting DK, Cebrian E, Casado C, Teixidó N, Garrabou J, Linares C (2015). Experimental evidence of the synergistic effects of warming and invasive algae on a temperate reef builder coral. Scientific Reports, $5: 18635$

Lages BG, Fleury BG, Ferreira CEL, Pereira RC (2006). Chemical defense of an exotic coral as invasion strategy. J Exper Mar Biol Ecol, 328: 127-135.

Lages BG, Fleury BG, Pinto AC, Creed JC (2010). Chemical defenses against generalist fish predators and fouling organisms in two invasive ahermatypic corals in the genus Tubastraea. Marine Ecology, 31: $473-$ 482.

Lages BG, Fleury BG, Menegola C, Creed JC (2011). Change in tropical rocky shore communities due to an alien coral invasion. Mar Ecol Progr Ser, 438: 85-96.

Lages BG, Fleury BG, Hovell AMC, Rezende CM, Pinto AC, Creed JC (2012). Proximity to competitors changes secondary metabolites of non-indigenous cup corals, Tubastraea spp., in the southwest Atlantic. Marine Biology, 159: 1551-1559.

Leão ZMAN, Kikuchi RKP, Oliveira MDM (2008). Branqueamento de corais nos recifes da Bahia e sua relação com eventos de anomalias térmicas nas águas superficiais do oceano. Biota Neotropica, 8 (3)

Lenz M, Da Gama BAP, Gerner NV, Gobin J, Gröner F, Harry A, Jenkins SR, Kraufvelin P, Mummelthei C, Sareyka J, Xavier EA, Wahl M (2011). Non-native marine invertebrates are more tolerant towards environmental stress than taxonomically related native species: Results from a globally replicated study. Environm Research, 111:943-952.

Lopes RM (2009). Informe sobre as espécies exóticas invasoras marinhas no Brasil. Ministério do Meio Ambiente, Curitiba, Paraná, Brazil 231p.

Luz BLP, Kitahara MV (2017). Could the invasive scleractinians Tubastraea coccinea and T. tagusensis replace the dominant zoantharian Palythoa caribaeorum in the Brazilian subtidal? Coral Reefs, 36: 875

Luz BLP, Capel KCC, Zilberberg C, Flores AAV, Migotto AE, Kitahara MV (2018). A polyp from nothing: The extreme regeneration capacity of the Atlantic invasive sun corals Tubastraea coccinea and $T$. tagusensis (Anthozoa, Scleractinia) J Exp Mar Biol Ecol 503: 60-65

Mangelli TS, Creed JC (2012). Análise comparativa da abundância do coral invasor Tubastraea spp. (Cnidaria: Anthozoa) em substratos naturais e artificiais na Ilha Grande, Rio de Janeiro, Brasil. Iheringia, Série Zoologia, Porto Alegre, 102(2): 122-130.

Mantelatto MC, Mourão GG, Migotto AE, Creed JC (2011). Range expansion of the invasive corals Tubastraea coccinea and Tubastraea tagusensis in the Southwest Atlantic. Coral Reefs, 30: 397.

Mantelatto MC (2012). Distribuição e abundância do coral invasor Tubastraea spp. MSc dissertation. Universidade Federal do Rio de Janeiro, Rio de Janeiro, RJ, Brazil, 121p.

Mizrahi D, Navarrete AS, Flores AAV (2014a). Groups travel further: pelagic metamorphosis and polyp clustering allow higher dispersal potential in sun coral propagules? Coral Reefs, 33: 443-448. 
Mizrahi D, Navarrete AS, Flores AAV (2014b). Uneven abundance of the invasive sun coral over habitat patches of different orientation: An outcome of larval or later benthic processes? Journal Experimental Marine Biology and Ecology, 452: 22-30

Mizrahi D, Pereira SF, Navarrete AS, Flores AAV (2017). Allelopathic effects on the sun-coral invasion: facilitation, inhibition and patterns of local biodiversity. Marine Biology, 164: 139.

Moreira TSG, Creed JC (2012). Invasive, non-indigenous corals in a tropical rocky shore environment: No evidence for generalist predation. J Exper Mar Biol Ecol 438:7-13

Nogueira JMM (2003) Fauna living in colonies of Mussismilia hispida (Verril) (Cnidaria: Scleractinia) in four Southeastern Brazilian islands. Braz Arch Biol Tech 46 (3): $421-432$

Nozawa Y, Harrison PL (2007). EVects of elevated temperature on larval settlement and post-settlement survival in scleractinian corals, Acropora solitaryensis and Favites chinensis. Marine Biology, 152: 11811185.

O'Connor MI, Bruno JF, Gaines SD, Halpern BS, Lester SE, Kinlan BP, Weiss JM (2007). Temperature control of larval dispersal and the implications for marine ecology, evolution and conservation. PNAS, 104 (4): 1266-1271.

Oigman-Pszczol SS, Figueiredo MAO, Creed JC (2004) Distribution of Benthic Communities on the Tropical Rocky Subtidal of Armação dos Búzios, Southeastern Brazil. Mar Ecol 25 (3): 173-190

Oliver TA, Palumbi SR (2011). Do fluctuating temperature environments elevate coral thermal tolerance? Coral Reefs, 30: 429-440.

PBMC, 2012: Sumário Executivo do Volume 1 - Base Científica das Mudanças Climáticas. Contribuição do Grupo de Trabalho 1 para o 1o Relatório de Avaliação Nacional do Painel Brasileiro de Mudanças Climáticas. Volume Especial para a Rio+20. PBMC, Rio de Janeiro, Brasil, 34 pp.

Pechenik JA (1990). Delayed metamorphosis by larvae of benthic marine invertebrates: does it occur? Is there a price to pay? Ophelia, 32: 63-94.

Rahel FJ, Olden JD (2008). Assessing the Effects of Climate Change on Aquatic Invasive Species. Conservation Biology, 22 (3): 521-533

Randall CJ, Szmant AM (2009a). Elevated temperature reduces survivorship and settlement of the Caribbean scleractinian coral, Favia fragum (Esper). Coral Reefs, 28: 537-545.

Randall CJ, Szmant AM (2009b). Elevated temperature affects development, survivorship and settlement of the Elkhorn Coral, Acropora palmata (Lamarck 1816). Biol Bull, 217: 269-282.

Ricciardi A, Rasmussen JB (1998). Predicting the identity and impact of future biological invaders: a priority for aquatic resource management. Can Journal Fisheries Aquatic Science, 55:1759-1765.

Riul P, Targino CH, Júnior LAC, Creed JC, Horta PA, Costa GC (2013). Invasive potential of the coral Tubastraea coccinea in the southwest Atlantic. Mar Ecol Progr Ser, 480: 73-81.

Ruiz GM, Carlton JT, Grosholz ED, Hines AH (1997). Global Invasions of Marine and Estuarine Habitats by NonIndigenous Species: Mechanisms, Extent, and Consequences. American Zoology, 37: 621-632.

Ruiz GM, Fofonoff PW, Carlton JT, Wonham MJ, Hines AH (2000). Invasion of Coastal Marine Communities in North America: Aparent Patterns, Processes, and Biases. Annual Review of Ecology and Systematics, 31: 481-531.

Sampaio CLS, Miranda RJ, Maia-Nogueira R, de Anchieta CC, Nunes J (2012). New occurrences of the nonindigenous orange cup corals Tubastraea coccinea and T. tagusensis (Scleractinia: Dendrophylliidae) in Southwestern Atlantic. Check List, 8: 528-530. 
Santos LAH, Ribeiro FV, Creed JC (2013). Antagonism between invasive pest corals Tubastraea spp. and the native reef-builder Mussismilia hispida in the southwest Atlantic. J Exper Mar Biol Ecol, 449: 69-76.

Sax DF, Gaines SD (2003). Species diversity: from global decrease to local increases. Trends in Ecology and Evolution, 18: 561-566.

Serrano XM, Miller MW, Hendee JC, Jensen BA, Gapayao JZ, Pasparakis C, Grosell M, Baker AC (2018). Effects of thermal stress and nitrate enrichment on the larval performance of two Caribbean reef corals. Coral reefs, 37: 173-182.

Sheppard CRC (1982). Coral populations on reef slopes and their major controls. Marine Ecology-Progress Series. 7(1):83-115.

Silva R, Vinagre C, Kitahara MV, Acorsi I, Mizrahi D, Flores AAV (2019). Sun coral invasion of shallow rocky reefs: effects on mobile invertebrate assemblages in Southeastern Brazil. Biol Invasions 21 (4): 13391350

Soares MO, Davis M, Carneiro PBM (2018). Northward range expansion of the invasive coral (Tubastraea tagusensis) in the southwestern Atlantic. Mar Biodiv, 48: 1651-1654

Thorson G (1950). Reproductive and larval ecology of marine bottom invertebrates. Biological Reviews of the Cambridge Philosophical Society, 25 (1): 1-45.

Vermeij MJA (2005). A novel growth strategy allows Tubastraea coccinea to escape small-scale adverse conditions and start over again. Coral Reefs, 24: 442

Vermeij MJA (2006). Early life-history dynamics of Caribbean coral species on artificial substratum: the importance of competition, growth and variation in life-history strategy. Coral Reefs, 25: 59-71. 


\section{Chapter 1: FOUNDER EFFECTS, ENVIRONMENTAL FILTERING AND NEUTRAL COEXISTENCE EXPLAIN LARGE TO SMALL-SCALE DISTRIBUTION PATTERNS OF INVASIVE SUN CORAL}

SPECIES IN THE SW ATLANTIC

Barbosa, A. C. C.; Vinagre, C.; Kitahara M.V.; Flores, A. A. V.

Abstract - Two sun coral species, Tubastraea tagusensis and T. coccinea, have successfully colonized reef habitats along the Southwest Atlantic, but studies so far had routinely addressed their invasive biology without considering species-specific distribution patterns. Here, we sampled vertical reef sites within a number of island locations along a $120 \mathrm{~km}$ coastline off the northern coast of São Paulo State to (i) investigate possible mechanisms underlying the invasion dynamics in the region, (ii) test species-specific distributions according to a key environmental filter (depth), and (iii) examine within-patch patterns to assess whether niche-based or neutral processes are best candidates to modulate species coexistence. Only 2 out of 9 locations remain uninvaded, and the chance of finding suncorals at any given reef site was estimated in 0.54 . The abundance of sun corals is particularly high at one particular island (Búzios), further suggesting that this was the first invaded location, probably functioning as a propagule source to sites within a range of tens of $\mathrm{km}$. There was substantial species segregation across locations, consistent to primary founder effects and secondary effects of local propagule pressure and environmental filtering. Within locations, results support species-specific depth distributions, with Tubastraea coccinea apparently in advantage in the more hydrodynamic environment just below the surf zone. At sun coral patches with substantial species co-occurrence, the presences of $T$. tagusensis and $T$. coccinea can be remarkably modeled as independent 
events, suggesting a case of neutral coexistence. Stochastic determination of small-scale species distributions makes any attempts to predict the spread of sun corals even more challenging.

Keywords: biological invasions; interspecific competition; resource partitioning; patch dynamics. 


\section{INTRODUCTION}

Sun corals, Tubastraea coccinea Lesson, 1829 and Tubastraea tagusensis Wells, 1982, are considered alien and invasive species in the South Atlantic Ocean (e.g. de Paula \& Creed 2004, Fenner \& Banks 2004, Ferreira 2003). These azooxanthellate scleractinian corals were first reported in Southeast Brazil in the late $80^{\prime}$ s, colonizing oil and gas platforms in the Campos Basin (Castro \& Pires 2001). More recently they have expanded to numerous sites along the Brazilian coast, across the states of Ceará (Soares et al. 2018), Bahia (Sampaio et al. 2012), Rio de Janeiro (de Paula \& Creed 2005), São Paulo (Mantelatto et al. 2011) and Santa Catarina (Lopes 2009). Both sun corals exhibit several characteristics that may have contributed to their successful invasion. They present high growth rates (Vermeij 2006), early maturation (Glynn et al. 2008) and high regeneration capacity (Luz et al. 2018). Adult colonies have the ability to reproduce sexually and asexually (Campbell 1983) and their larvae can metamorphose into planktonic polyps, which might enhance their dispersal potential (Mizrahi et al. 2014, Barbosa et al. submitted). There is evidence of their competitive dominance over native corals (Creed 2006, dos Santos et al. 2013) and zoanthids (Luz \& Kitahara 2017), and their capacity to inhibit recruitment of other species through negative allelopathic interactions (Lages et al. 2006, 2010). Additionally, sun corals can cope with substantial environmental change (Lenz et al. 2011) and lack any known natural predators in the Southwest (SW) Atlantic (Lages et al. 2010, Moreira \& Creed 2012). The traits above, combined to the fact that sun corals may locally spread through polyp bail-out (Capel et al. 2014) or colony fragmentation (Luz et al. 2018), should have greatly contributed to the present-day generalized dominance of sun corals at sites where first colonization backs to just about a decade (as Búzios Island, SP, Brazil; Mantelatto et al. 
2011). Because sun corals recreate reef physical structure, we anticipate strong founder effects (Vieira et al. 2018a, b), setting novel successional pathways at invaded areas.

Considered a cosmopolitan species, $T$. coccinea was first described from Bora Bora Island, French Polynesia, with a natural range throughout the Indo-Pacific (Cairns 1994). This species has recently spread over the Caribbean Sea, Gulf of Mexico (Fenner \& Banks 2004) and along the SW Atlantic (da Silva et al. 2011, 2014). Its congener, T. tagusensis, was first described from the Galapagos Archipelago, Ecuador, and is considered invasive to the SW Atlantic (da Silva et al. 2011, 2014, Creed et al. 2016). Both sun corals species are invasive in Brazilian coastal reefs, and at some sites they almost saturate space over patch sizes ranging from several tens to a few hundred meters long, especially on vertical walls (da Silva et al. 2014, Silva et al. 2019), where the two species frequently co-occur (da Silva et al. 2014, Creed et al. 2016, Silva et al. 2019). On vertical walls along homogenous rocky reef habitats, colonies of $T$. coccinea and $T$. tagusensis are often found intermingled within distinctive 'sun-coral patches' (Fig. 1A). More rarely, and usually at more fragmented reef habitats such as boulders and man-made structures, these sun coral species may segregate within patches, forming clusters of considerable size (Fig. 1B). Understanding the distribution patterns of these co-occurring species at relevant spatial scales is a first step to frame more specific hypotheses on the nature of the interactions between them, as well as mechanisms of resource partitioning, which are largely unknown. 

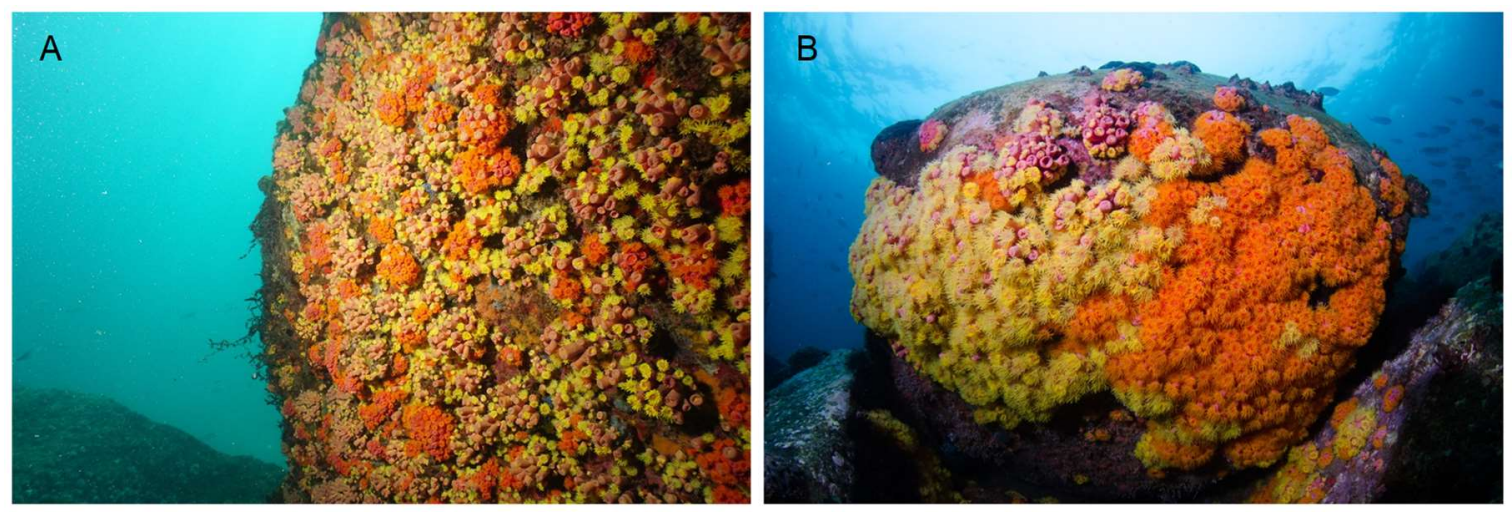

Figure 1. Within-patch distribution patterns of yellow (Tubastraea tagusensis) and orange ( $T$. coccinea) sun corals in (A) typical main-reef vertical walls, and (B) less-common fragmented boulder habitats. Photo credits: Marcelo V. Kitahara (A) and Leo Francini (B).

Some indirect evidence on sun-coral species differences of habitat use, based on morphology and potential thermal niche, can be used as starting points. Compared to $T$. tagusensis, T. coccinea corallites are shorter and colonies flatter (Mangelli and Creed 2012, de Paula et al. 2014), which could eventually render the latter an advantage at shallowwater habitats, more directly exposed to wave forces (Mantelatto 2012). Living close to the surface also requires tolerance to high temperature. The temperature regimes at native geographic ranges further suggest an advantage of $T$. coccinea at shallow reef habitats, as this species is thought to be originally widespread over the warm tropical Indo-Pacific ocean, while T. tagusensis was restricted to the Galapagos Islands, where historical average monthly temperatures range from 21.4 to just $25.8^{\circ} \mathrm{C}$ at the surface (www.seatemperature.org). There are apparently no constraints of localized low temperature at depth, as long as both species have been found below $40 \mathrm{~m}$ at native sites (Wells 1982, Cairns 1994). Thus, it is plausible to predict that T. coccinea would tend to occupy shallow warmer and more turbulent reef habitats, while T. tagusensis would be displaced to deeper, less turbulent and cooler reef areas. We are not aware or any studies 
so far that had investigated species-specific depth distributions at places where both sun corals co-occur.

Unlike physical drivers, the effects of biological factors, such as the outcomes of species interactions and the supply of suitable habitat and food resources, typically operate at much smaller spatial scales, compatible to the complex patch dynamics of natural reef systems. Notably, sun corals typically select smooth habitat patches (such as those delimited by encrusting coralline algae) as settlement grounds (Mizrahi et al. 2017), potentially leading to a clustered distribution of individual colonies and positive associations of sun coral species at spatial scales in the order of tens of centimeters. Inversely, interspecific interference competition may cause reduced growth (Sammarco et al. 1983, Tanner 1997), damage (Lapid et al. 2004, Hennessey \& Sammarco 2014), partial mortality or total smothering (Idjadi \& Karlson 2007) of the lower ranked species, ultimately leading to spatial segregation (i.e. negative spatial associations) of interacting corals. Sun corals are known to infringe tissue necrosis and reduced growth upon contact with native corals in nature (Creed 2006, dos Santos et al. 2013, Barbosa et al. submitted), but interactions between $T$. tagusensis and $T$. coccinea have to our best knowledge never been tested. Hennessey \& Sammarco (2014), however, had examined contact interactions between $T$. coccinea and the congener Tubastraea micranthus in the Gulf of Mexico, without evidence of aggression or competitive interactions, and concluded these species recognized each other as 'self'.

Among all possible networks of species interactions, competition among dominant species may shape whole benthic ecosystems (Menge 1976, Lubchenco 1980). In the case of invasive sun corals species, potentially monopolizing and drastically changing the physical structure of vast reef extensions (Lages et al. 2011, Silva et al. 2019), understanding 
the interaction outcomes between the two Tubastraea species is of paramount importance to predict the state of invaded reefs and assess the likelihood of colonization of still unaffected locations in the long run. Here, we examined the co-occurrence of $T$. tagusensis and $T$. coccinea at several different spatial scales to identify possible ecological processes, from long-distance dispersal to local competition and resource partitioning, which may determine these species' distributions in the SW Atlantic. Namely, we mapped and quantified the abundance of invasive sun coral species at coastal Islands off the central and northern coast of São Paulo State, Brazil, encompassing a linear coastline of $120 \mathrm{~km}$. At more local scales, we tested whether depth-distributions are compatible to predictions based on colony morphology and potential thermal niche, and whether species associations at the patch level support niche related processes (e.g. interspecific competition and species fitness differences, patterns of resource exploitation, etc.), or alternatively a neutral coexistence, ruled by more stochastic processes.

\section{MATERIALS AND METHODS}

\section{Field work}

The current distribution and abundance of sun corals Tubastraea spp. at costal island habitats off the central and northern coast of São Paulo State, Brazil, were surveyed through snorkeling and scuba diving from May to September 2018. We restricted this study to regular, nearly vertical reef walls, which is the most frequent insular reef habitat in the study region. Seven locations were sampled, encompassing a coastline length ranging from 2 to $8 \mathrm{~km}$ and distributed over five islands of different size. Small islands Vitória, Búzios, Toque-toque and Montão de Trigo were considered single locations. Three different locations were sampled at the larger Ilhabela (Fig. 2). Within each location, two snorkeling 
divers searched for sun coral colonies at five random 150 m coastlines (hereafter 'sites'), for approximately $10^{\prime}$, and classified their abundance into six categories (Table 1). At any given site where abundance was assigned category 3 (very common) or higher, scuba-dive sessions were undertaken to estimate the percent cover of both yellow ( $T$. tagusensis) and orange ( $T$. coccinea) sun corals at three different depth intervals, encompassing most reef habitat available in these islands: 2-4 m (shallow), 6-8 m (mid) and 10-12 m (deep). At each depth, 20 photographs at random positions within sun coral patches were taken using a $0.5 \times 0.5 \mathrm{~m}$ frame. The minimum spacing between positions was $1 \mathrm{~m}$. At Montão de Trigo sampling was restricted to the two shallowest levels because the maximum reef depth at that site is $9 \mathrm{~m}$. Data from two additional locations, Laje de Santos and Farol do Moleque (Fig. 1), were also obtained, but access was only possible to a single random site (category 3 and 2, respectively). At Laje de Santos, the shallow reef was not the regular target habitat (vertical homogeneous bedrock) and percent cover estimates were only obtained at intermediate and deep strata. Snorkeling at multiple sites was not possible at this location and therefore overall cover was not estimated.

Table 1. Frequency categories used for a rapid assessment of the abundance of sun corals (Tubastraea spp.) at island reef sites off São Sebastião, SP, Brazil.

\begin{tabular}{|c|c|c|}
\hline \multicolumn{2}{|c|}{ Category } & \multirow{2}{*}{$\begin{array}{l}\text { Description } \\
\text { No sun-coral colonies observed }\end{array}$} \\
\hline 0 & Absent & \\
\hline 1 & Occasional & $\begin{array}{l}\text { Mostly single isolated colonies. Aggregations over } 1 \mathrm{~m}^{2} \text { (= patches) are rare } \\
\text { and thin }(<10 \% \text { cover) }\end{array}$ \\
\hline 2 & Common & High-density patches (> 10\%) present but not frequent (less than 5 ) \\
\hline 3 & Very common & High density patches frequent ( 10 or more) \\
\hline 4 & Abundant & $\begin{array}{l}\text { Uniform cover, frequently } 50 \% \text { or more, over large reef extensions (> } 10 \\
\text { m) }\end{array}$ \\
\hline 5 & Dominant & $\begin{array}{l}\text { Most vertical substrates dominated by sun corals. Cover frequently } \\
\text { reached saturation }(90-100 \%)\end{array}$ \\
\hline
\end{tabular}



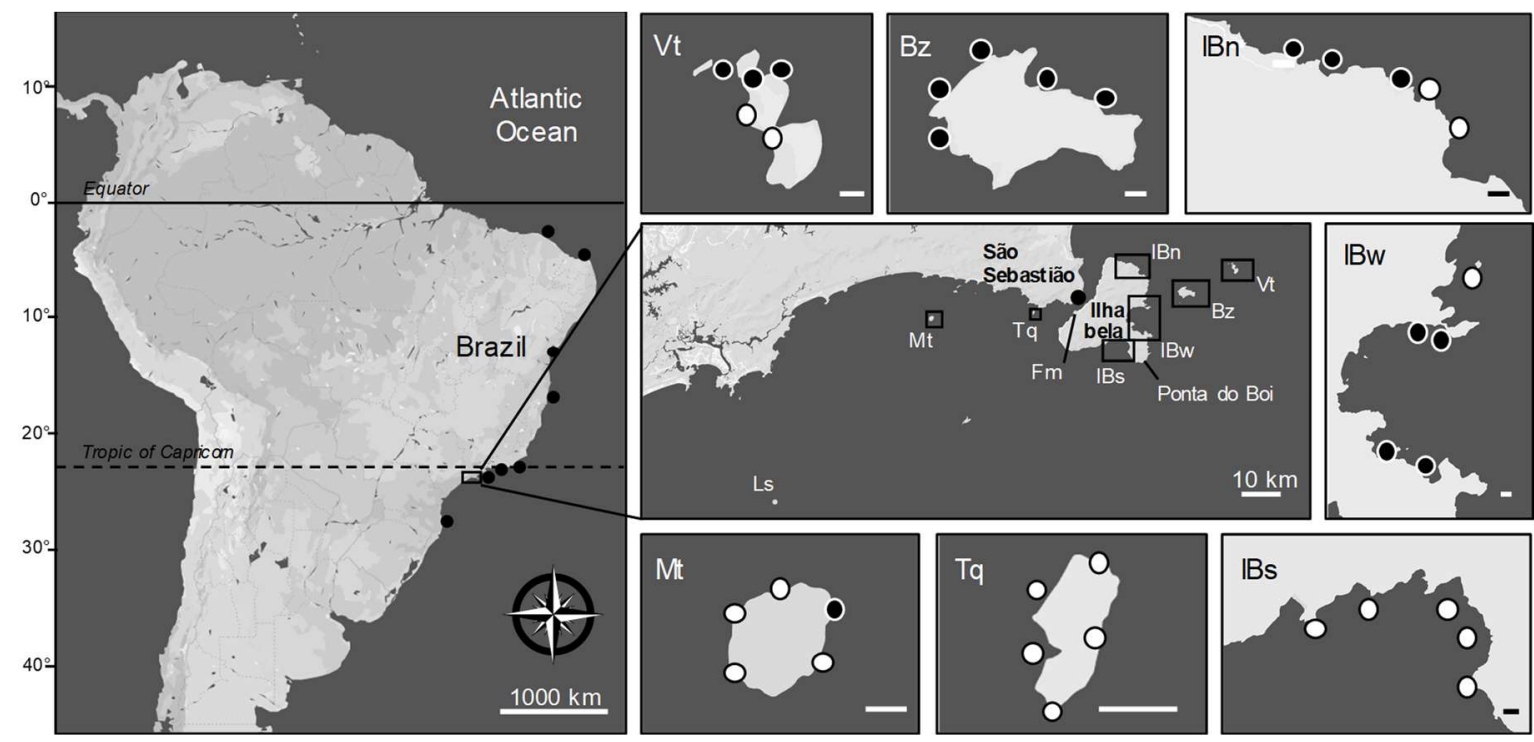

Figure 2. Map of South America (left), showing the main localities where sun corals were reported along the invasive range in Brazil (black dots), and coastline of the study region, encompassing island habitats off São Sebastião and Ilhabela (centre). Clockwise, close detail of study locations: Vitória (Vt), Búzios (Bz), Ilhabela north (IBn), Ilhabela west (IBw), Ilhabela south (IBs), Toque-toque $(\mathrm{Tq})$, and Montão de Trigo (Mt). Black and white dots indicate sites where sun corals were present and absent, respectively. Details at Laje de Santos (Ls) and Farol do Moleque (Fm) are not shown as sampling was restricted to a single site in those locations. Scale bars: $500 \mathrm{~m}$.

\section{Image analyses}

Within-patch abundance was quantified for whole-quadrat digital images using the point-count method (100 points over a grid). Because we were also interested in smallscale association patterns between sun coral species, we verified their presence in nonoverlapping sub-quadrats, four for each image, of sizes $10 \times 10,15 \times 15,20 \times 20$ and $25 \times$ $25 \mathrm{~cm}$. Besides their color, sun coral species could also be distinguished by corallite shape; short in T. coccinea and elongated in T. tagusensis, confirming the diagnoses in Mantelatto (2012). 


\section{$\underline{\text { Statistical analyses }}$}

Overall abundance of sun corals (both species combined) among locations that could be fully sampled was compared using a one-way analysis of variance on raw data. Depth distributions were tested using two-way mixed-model GLMs in which 'depth' and 'location' were considered fixed and random factors, respectively. A significant interaction term 'depth*location' would indicate spatial inconsistencies of any eventual depth trends. Separate analyses were run for $T$. tagusensis (raw data) and $T$. coccinea (arc-sin transformed to meet homoscedasticity) because the two only locations with presence at all depth intervals were not the same for the two species. For both overall sun coral abundance and species-specific depth distributions the SNK procedure was used for $a$ posteriori pairwise comparisons.

Differences in the relative abundance of sun coral species across sites were clearcut (see 'Results') and no statistical analyses were needed to test them. Species associations that could indicate, for instance, aggregation at favorable habitat conditions (positive) or interspecific competition (negative) at the whole-quadrat scale $(50 \times 50 \mathrm{~cm}$ ) were tested using Pearson correlation coefficients based on the percentage cover of the two species. At the smaller within-quadrat scales (from $10 \times 10$ to $25 \times 25 \mathrm{~cm}$ sub-quadrats), presence/absence data were drawn instead, and the frequency of units with (i) no coral species, (ii) T. tagusensis only, (iii) T. coccinea only, and (iv) both species together, was recorded. Observed frequencies were then contrasted with frequencies generated from null models assuming the occurrence of the two species as independent events. Departures from expected frequencies were tested using a G-test, with degrees of freedom corrected for an intrinsic hypothesis based on observations (i.e. the proportion of units containing $T$. tagusensis and T. coccinea). 
RESULTS

Overall sun coral abundance

Invasive sun corals were present at seven of the nine sampled locations (Fig. 2), and 20 out of the 37 sites visited (including single-site surveys at Laje de Santos and Farol do Moleque; Fig. 3A). Therefore, the chances of finding any sun coral species at any single site within this study region is nearly 0.54 (i.e. it is more likely to find sun corals than not to find them). When present, the most frequent abundance category was 'very common' (category ' 3 '; Fig. 3A), suggesting that the formation of high-density patches may be relatively fast after first colonization. The comparison among locations that could be fully sampled ( $\mathrm{n}=5$ sites; $F=10.4, p=0.0001$ ) showed no clear geographic trends, from northeast to southwest, with the abundance at Búzios Island being much higher than all remaining sites where sun corals were also present (Fig. 3B, $p<0.01$ ). Still, it is important to note that sun corals at all three sites west from Ponta do Boi, Ilhabela (Fig. 2), were either absent (Ilhabela South and Toque-toque) or occasional (Montão de Trigo) at most (Fig. 3B).

\section{$\underline{\text { Species-specific depth distributions }}$}

There is a clear overall segregation of sun coral species across study locations (Fig. 4). The relative abundance of $T$. tagusensis is higher at Vitória and, mostly, Búzios, while $T$. coccinea clearly prevailed at Ilhabela West and Laje de Santos, where no T. tagusensis was observed at all. Depth distribution patterns were tested at locations where sun coral species were found at all depth strata, making orthogonal analyses possible. Those were Vitória and Búzios for T. tagusensis and Vitória and Ilhabela West for T. coccinea (Fig. 4). For both species, the depth*location interaction term was statistically significant, indicating that depth distributions were not consistent between locations (T. tagusensis, $F$ 
$=9.0, p=0.0002 ;$. coccinea $F=30.7, p<0.0001) . T$. tagusensis tend to be more abundant at deeper reef habitats, but with peak abundance varying from deep (Vitória) to mid (Búzios) strata $(p<0.01)$. Likewise, $T$. coccinea rather occupy shallower habitats, but higher cover estimates were observed at either shallow (Vitória) or mid depth (Ilhabela West, $p<$ 0.01; Fig. 4). No other pairwise comparisons were significant.
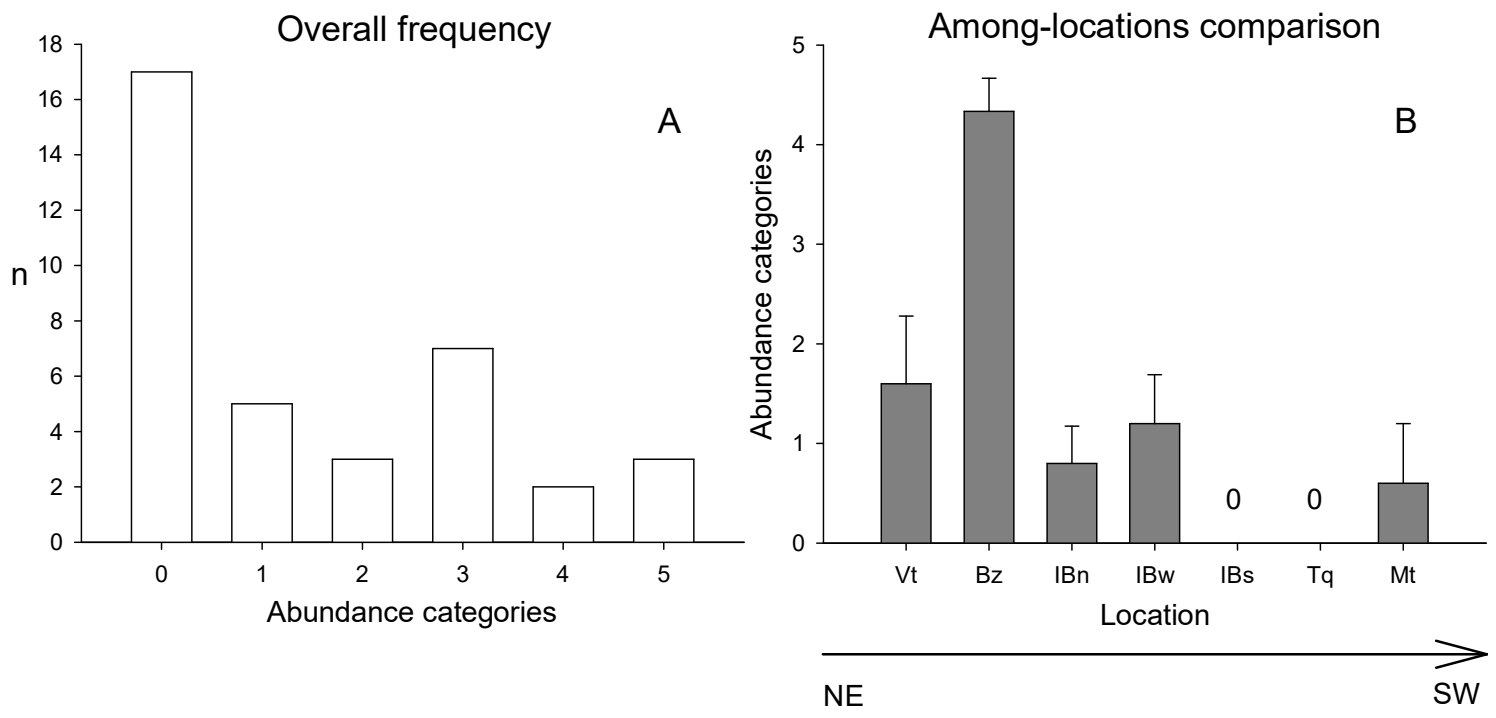

Figure 3. Overall frequency of sun-coral abundance categories (sites pooled across locations; A), and abundance comparison among locations (B). Error bars stand for $\pm 1 \mathrm{SE}$. 


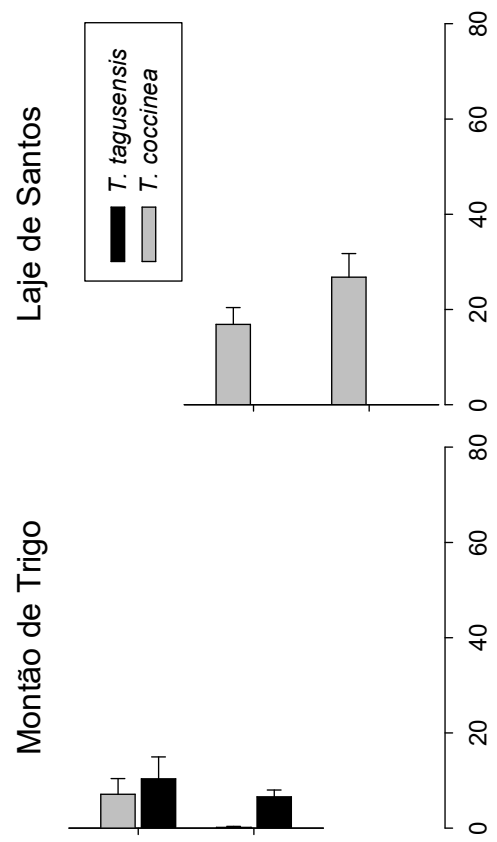

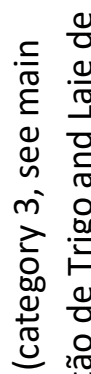

हิ

ह

$\geq \stackrel{4}{\square}$

$>$

은 은

ర్d

든 음

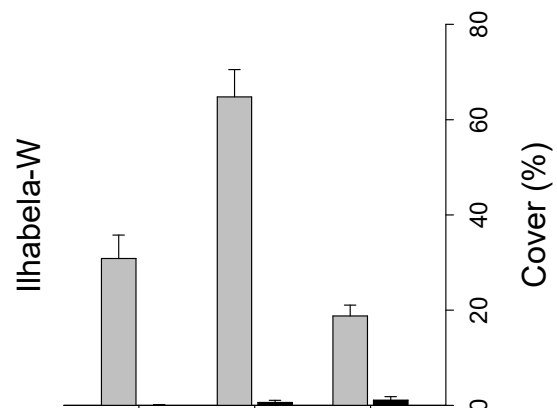

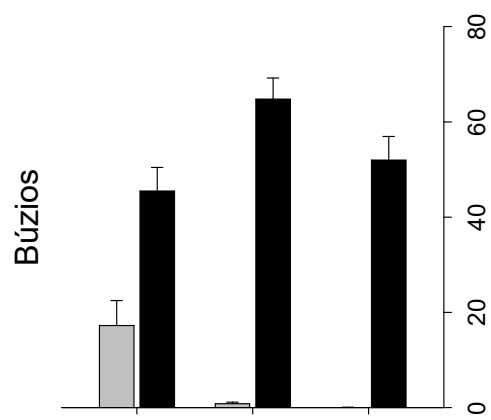

$\frac{n}{\pi}$

웡

ज施

पั口

㟧

응

을

$\stackrel{2}{\frac{n}{5}}$

¿

उ

ज放

ज范京

气 :

을 둥

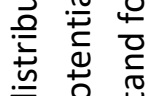

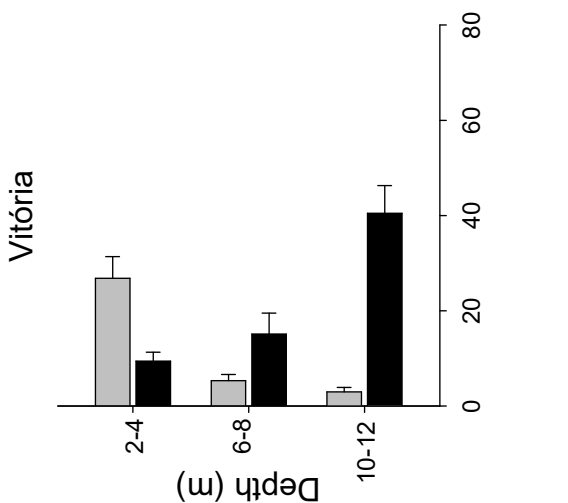

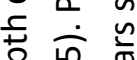

응 约

원은

恼 严

षृ

प

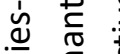

迄

+

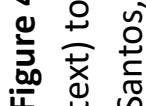




\section{Species co-occurrences}

We restricted analyses to depth strata, within locations, where average sun coral cover was $20 \%$ or more and the presence of both species was not negligible (> $3 \%)$, i.e. Vitória shallow, intermediate and deep, and Búzios shallow (Fig. 4). Based on percent cover estimates, no apparent patterns of species associations, either positive or negative, were observed at the whole-quadrat scale in all cases (Pearson correlation coefficients, $0.045<$ $r<0.326 ; 0.161<p<0.851 ;$ Fig. 5). Independent species co-occurrences were also supported by analyses on presence-absence data at smaller scales, from $10 \times 10$ to $25 \times 25$ $\mathrm{cm}$ (Fig. 6). Observed frequencies of sub-quadrats with no sun corals, with only a single species (either T. tagusensis or T. coccinea) and with both species remarkably followed the expected frequencies based on null models, assuming that, the presence of the two sun corals species are independent events. Negligible departures from expectations were the rule across depth strata within locations and sub-quadrat size $(0.05<G<2.07 ; 0.151<p<$ 0.957; Fig. 6). Therefore, there is no sign of association, either positive or negative, between the occurrences of these species. Notably, we discard sampling artifacts owing to species exclusion at even the smaller scale $(10 \times 10 \mathrm{~cm})$. Such an effect would lead to higher frequencies of single-species and lower frequencies of two-species counts compared to expectations, which was not the case. 


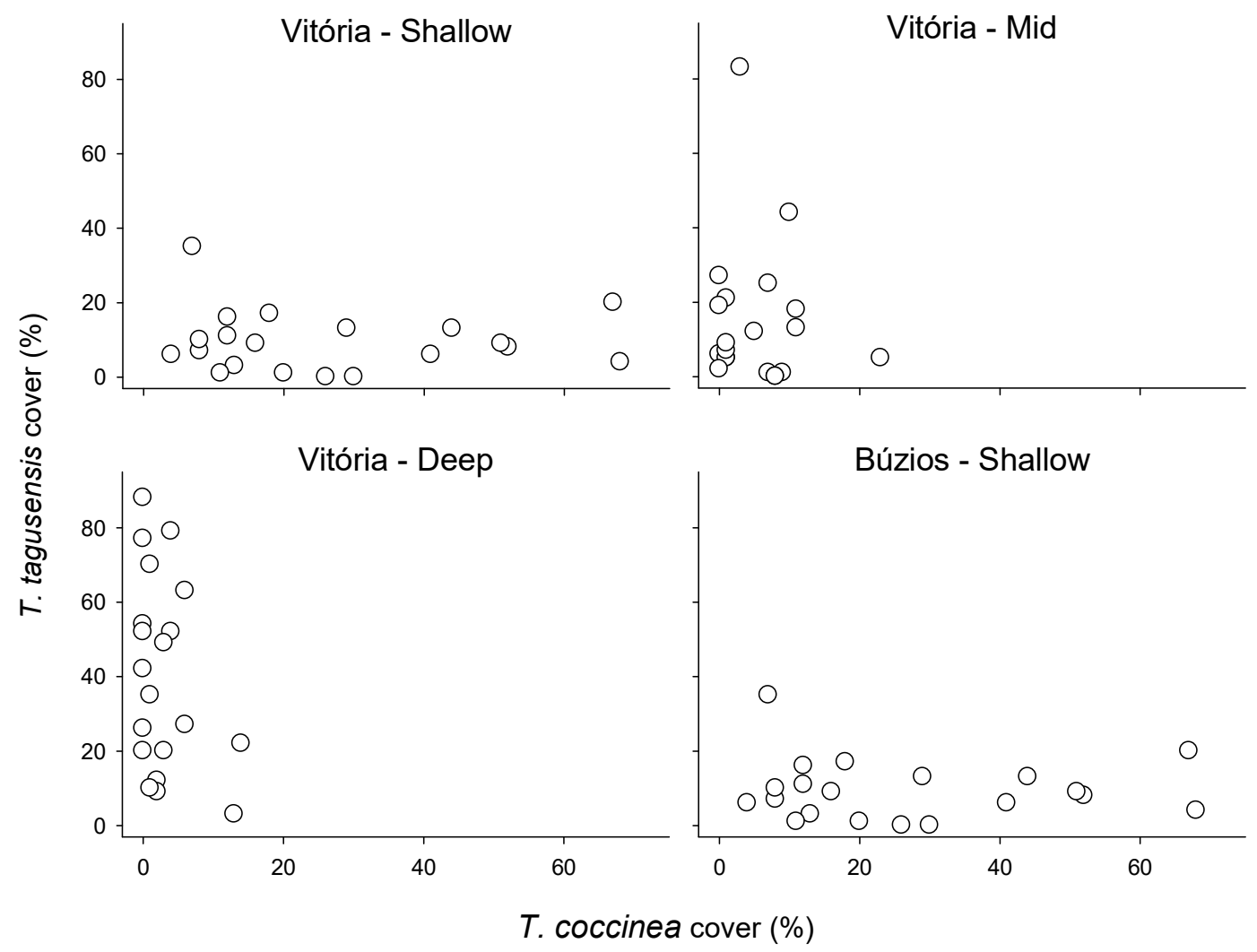

Figure 5. Scatterplots showing the absence of any linear relationships between whole-plot $(50 \times 50$ $\mathrm{cm}, \mathrm{N}=20$ ) abundances of Tubastraea tagusensis and $T$. coccinea at Vitória (all depths) and Búzios (shallow reef), where average sun-coral cover was $20 \%$ or more and the presence of both species was not negligible (> 3\%). 

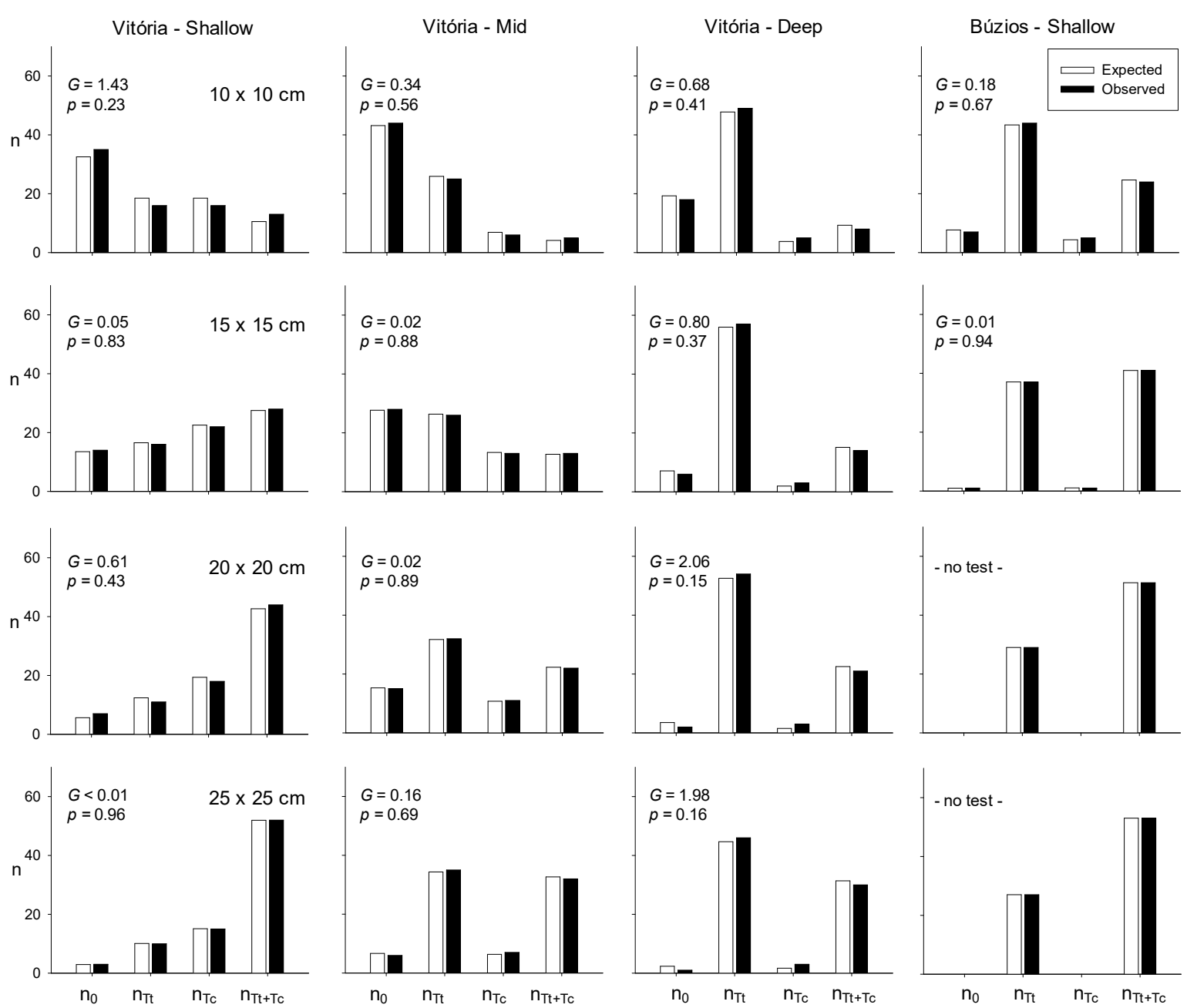

Figure 6. Small-scale within-plot species co-occurrences at the locations examined in Figure 5 (from $10 \times 10$ to $25 \times 25 \mathrm{~cm}$ sub-quadrats, $\mathrm{N}=80$ in each case). In all cases, observed frequency distributions remarkably approximate the expected distributions based on chance alone, considering the presence of the two sun corals independent events. The presence-absence categories in $x$-axes correspond to the absence of both species $\left(n_{0}\right)$, presence of Tubastraea tagusensis only $\left(\mathrm{n}_{T \mathrm{~T}}\right)$, presence of $T$. coccinea only $\left(\mathrm{n}_{T \mathrm{~T}}\right)$, and presence of both species $\left(\mathrm{n}_{T t+T_{C}}\right)$. 


\section{DISCUSSION}

The results presented in this study suggest that several different factors modulate the distribution of sun coral species off the northern coast of São Paulo State, Brazil, close to the southernmost limit of their invasive range along the SW Atlantic. Orange and yellow sun corals are largely segregated among islands, separated by tens of $\mathrm{km}$, but, withinislands, depth and simple patch-dynamics apparently play a role in the determination of species distributions at places where Tubastraea tagusensis and T. coccinea co-occur. We discuss below the plausible mechanisms that may underlie sun coral species distributions in the study area, based on the patterns observed.

At the larger scale considered here, the abundance patterns observed among sample islands suggest a dominant 'mainland-island' metapopulation type (Harrison 1991), in which a single location may ultimately seed a number of others. After about a decade of colonization in our study area (Mantelatto et al. 2011), Búzios Island became very heavily colonized by sun corals, clearly standing out from the other sampled locations. This more formal comparison, strengthens the notion that Búzios was the first invaded location in the area, currently functioning as a propagule source to sites separated by a few tens of km, such as Vitória, Ilhabela North and Ilhabela West (Fig. 2). While the oil industry may have indeed facilitated the spread of sun corals through the traffic of tankers, oil platforms and monobuoys accidentally fouled with large reproducing colonies (da Silva et al. 2014, Creed et al. 2016), propagules released by large adult-colony aggregations at invaded natural reef habitats, as the ones found at Búzios Island, may spend much longer in the plankton (Mizrahi et al. 2014, Barbosa et al. submitted) than often assumed for sun-coral planulae (Glynn et al. 2008), and reach proper reef habitats several km apart. Interestingly, the 3 southwestern-most sampled locations (Figs. 2, 3) were still either free of sun corals 
(Ilhabela South and Toque-toque), or only barely colonized (Montão de Trigo), suggesting that the headland at Ponta do Boi (Fig. 2) may work as a barrier to larval dispersal. It is noteworthy that the single site where sun corals were found at Montão de Trigo is near a small fishermen's settlement, suggesting accidental introduction through fouling rather than colonization through 'natural' propagule dispersion.

It is interesting to note, however, that sun-coral species are strongly segregated among the sampled island locations, indicating that, after first establishment, propagation within and to nearby suitable habitat patches may be achieved through mechanisms other than pelagic larval dispersal. Asexual means of propagation, including polyp bail-out (Capel et al. 2014) and colony fragmentation (Luz et al. 2018), which explain the very low genetic variation along the SW Atlantic invasive range (Capel et al. 2017), may play a key role in local patch dynamics. This way, single-species first introductions may partially condition later successional stages, consistent to founder effects leading to relatively fast space monopolization by the fortuitous arrival of a dominant species (as in Vieira et al. 2018a, b). Propagule pressure and environmental filtering may secondarily contribute to patch dynamics and stabilize asymmetric species proportions at advanced invasion stages (i.e. towards T. coccinea at Ilhabela West and Laje de Santos and T. tagusensis at Búzios and Vitória). While the 'regional' larval pool (Caley et al. 1996, Barbosa et al. 2016), coupled to stochastic transport mechanisms, may modulate uncertain settlement and recruitment patterns to vacant space, our results support a predictable effect of wave action (or heat stress) on the relative ability of sun coral species to colonize shallower reef patches. Although not totally consistent between sampled locations, the highest percent cover was observed at mid and deep strata for $T$. tagusensis, and mid and shallow strata for $T$. coccinea, as anticipated by morphological evidence (Mangelli \& Creed 2012) and thermal 
regimes at the original ecoregions of these invading species. Moreover, more balanced species abundances were observed at shallow strata of reefs overall dominated by $T$. tagusensis (Vitória and Búzios), suggesting that T. coccinea does have an advantage at more turbulent (or thermally vulnerable) environments, just below the surf zone. This same reasoning would explain why $T$. tagusensis was present at mid and deep but not at the shallow depth interval in Ilhabela West. Aligned to our findings, Sammarco and co-workers (2013) verified that the average depth of $T$. coccinea was generally lower than the average depth of $T$. micranthus at oil platforms in the Gulf of Mexico, where both species are invasive.

The seemingly higher performance of $T$. coccinea at shallow depth allows extensive co-occurrence between the two species, probably without implying any sort of negative interactions between them. Both sun corals have shown to be strong interspecific competitors, causing tissue necrosis and partial mortality in native corals (Creed 2006, dos Santos et al. 2013, Henessey \& Sammarco 2014) and zoanthids (Luz \& Kitahara 2017), but the analyses undertaken in this study did not reveal any negative associations between the two invasive sun corals at scales capable to detect spatial segregation patterns attributable to direct competition. Thus, we accept at this stage the conclusions of Henessey \& Sammarco (2014) on T. coccinea and T. micranthus, i.e. that co-occurring sun corals are very closely related species that do not perceive each other as a threat. As such, one could expect that $T$. tagusensis and $T$. coccinea would share the same resources and exhibit very close habitat preferences within the mosaic-kind reef environment, usually very patchy at scales of only a few tens of centimeters, or smaller (Gratwicke \& Speight 2005, Boström et al. 2011). Namely, we would expect a positive trend in the scatterplots of figure 5, or a higher-than-expected frequency of plots with both species in figure 6 , which were not 
observed. Unlike closely related barnacle species, which exhibit wide niche overlap and cluster together in intertidal rocky shores of Central Chile (Shinen \& Navarrete 2014), or congeneric limpets that graze on similar food items and segregate at small spatial scales (Aguilera et al. 2013), the spatial distributions of invasive sun corals $T$. coccinea and $T$. tagusensis are surprisingly well described by null models assuming that the occurrences of these species are independent events (Fig. 6). Without having attempted any manipulative experiments aiming proper experimental testing, the spatial analyses carried out in this study do not sustain any clear niche-related hypotheses (e.g. competition, resource partitioning, facilitation, etc.), but rather suggest a case of neutral coexistence, where both fitness, competitive ability and dispersal potential are so similar that one species is unable to exclude the other (Chesson 2000, Adler et al. 2007, Hubbell 1997).

Though we did not test the 'invasibility' of sun corals (i.e. 'the ability of a species to increase from low density in the presence of the rest of the community'; Chesson 2000), we assumed this is the case since T. coccinea and T. tagusensis, as successful invaders, have repeatedly observed to increase their densities from very low or null initial coverage. The model of neutral coexistence (Hubbell 1997, Chesson 2000) was conceived for species that share the same trophic level and are similar in size and general morphology, so that they could be pooled into a single functional group (Amarasekare 2003, Adler et al. 2007, Shinen \& Navarrete 2010). Orange and yellow sun corals are apparently two species of a very specific kind, whose coexistence at the patch scale-range is likely ruled by neutral processes. Also, studies to date have failed to identify any potential predators (Lages et al. 2010, Moreira \& Creed 2012), or any equal or superior competitors (Hennessey \& Sammarco 2014, Sammarco et al. 2015), capable of regulating these corals distribution and abundance. As such, the evident success of the sun-coral invasion in the SW Atlantic could 
also be predicted by the 'enemy release hypothesis' (Keane \& Crawley 2002), which states that exotic species, when introduced into a novel region, are often initially released of strong predation and competition, and therefore their local density and the rate of their spread over other areas are very high compared to native species. Potential neutral-like coexistence raises additional concerns when it comes to control the sun coral invasion, as independent species occurrences are probably underlied by rather small-scale stochastic environmental drives, which are by definition difficult to anticipate.

\section{ACKNOWLEDGEMENTS}

We gratefully acknowledge the CEBIMar technicians Joseilto Medeiros de Oliveira and Eduardo Onuma for their help in field and also José Jerônimo P. Favaro for the quadrats confection. This research was funded by the Program "Ciência sem Fronteiras" (CNPq; Conselho Nacional de Desenvolvimento Científico e Tecnológico; Grant \# 400614/2014-6), as a Special Visiting Researcher Fellowship - PVE to CV. We also thank the USP Graduate

Program in Comparative Biology for granting a PhD fellowship to ACCB (CNPq \# 159822/2015-7). This is a contribution of the Research Centre for Marine Biodiversity of the University of São Paulo (NP-Biomar/USP).

\section{REFERENCES}

Adler PB, HilleRisLambers J, Levine JM (2007) A niche for neutrality. Ecol Lett 10: 95-104

Aguilera MA, Valdivia N, Broitman BR (2013) Spatial niche differentiation and coexistence at the edge: cooccurrence distribution patterns in Scurria limpets. Mar Ecol Prog Ser 483: 185-198

Amarasekare P (2003) Competitive coexistence in spatially structured environments: a synthesis. Ecol Lett 6 : 1109-1122

Barbosa ACC, Gomes CC, Pereira GC, Bueno M, Flores AAV (2016) Local biological drivers, not remote forcing, predict settlement rate to a subtropical barnacle population. Mar Ecol Prog Ser 543: 201-208 
Barbosa ACC, Vinagre C, Mizrahi D, Duarte RC, Flores AAC (submitted) Invasive sun corals and warming pose independent threats to the brain coral Mussismilia hispida in the Southwestern Atlantic. Mar Ecol Prog Ser

Barbosa ACC, Vinagre C, Mizrahi D, Flores ACC (submitted) Temperature-driven secondary competence windows may increase the dispersal potential of invasive sun corals. Mar Biol

Boström C, Pittman SJ, Simenstad C, Kneib RT (2011) Seascape ecology of coastal biogenic habitats: advances, gaps, and challenges. Mar Ecol Prog Ser 427: 191-217

Cairns SD (1994) Scleractinia of the Temperate North Pacific. Smithsonian Contributions to Zoology, 557. Smithsonian Institution Press, Washington, D.C.

Caley MJ, Carr MH, Hixon MA, Hughes TP, Jones GP, Menge BA (1996) Recruitment and the local dynamics of open marine populations. Annual Rev Ecol Syst 27: 477-500

Campbell RD (1983) Cnidaria. In Giese, AC e Pearse, JS (eds): Reproduction of marine invertebrates I. Academic Press New York, 133-200

Capel KCC, Migotto AE, Zilberberg C, Kitahara MV (2014) Another tool towards invasion? Polyp "bail-out" in Tubastraea coccinea. Coral Reefs 33: 1165

Capel KCC, Toonen RJ, Rachid CTCC, Creed JC, Kitahara MV, Forsman Z, Zilberberg C. (2017) Clone wars: asexual reproduction dominates in the invasive range of Tubastraea spp. (Anthozoa: Scleractinia) in the South-Atlantic Ocean. PeerJ 5: e3873

Castro CB, Pires DO (2001) Brazilian coral reefs: what we already know and what is still missing. Bull Mar Sci 69: $357-371$

Chesson P (2010) Mechanisms of maintenance of species diversity. Annu Rev Ecol Syst 31: 343-66

Creed JC (2006) Two invasive alien azooxanthellate corals, Tubastraea coccinea and Tubastraea tagusensis, dominate the native zooxanthellate Mussismilia hispida in Brazil. Coral Reefs 25:350

Creed JC, Fenner D, Sammarco PW, Cairns S, Capel KCC, Junqueira AOR, Cruz I, Miranda RJ, Carlos-Júnior LA, Mantelatto MC, Oigman-Pszczol SS (2016) The invasion of the azooxanthellate coral Tubastraea (Scleractinia: Dendrophylliidae) throughout the world: history, pathways and vectors. Biol Invasions 19 : 283-305

Da Silva AG, Lima RP, Gomes AN, Fleury BG, Creed JC (2011) Expansion of the invasive corals Tubastraea coccinea and Tubastraea tagusensis into the Tamoios Ecological Station Marine Protected Area, Brazil. Aquat Invas 6(1): S105-S110

Da Silva AG, De Paula AF, Fleury BG, Creed JC (2014) Eleven years of range expansion of two invasive corals (Tubastraea coccinea and Tubastraea tagusensis) through the southwest Atlantic (Brazil). Estuarine, Coastal and Shelf Science 141: 9-16

De Paula AF, Creed JC (2004) Two species of the coral Tubastraea (Cnidaria, Sclerectinia) in Brazil: a case of accidental introduction. Bull Mar Sci 74: 175-183

De Paula, AF, Creed, JC (2005) Spatial distribution and abundance of non-indigenous coral genus Tubastraea (Cnidaria, Scleractinia) around Ilha Grande, Brazil. Braz J Biol 65: 661-673

De Paula, AF, Pires DO, Creed JC (2014) Reproductive strategies of two invasive sun corals (Tubastraea spp.) in the southwestern Atlantic. J Mar Biol Assoc UK 94: 481-492 
Done TJ (1982) Patterns in the Distribution of Coral Communities Across the Central Great Barrier Reef. Coral Reefs 1: 95-107

Dos Santos LAH, Ribeiro FV, Creed JC (2013) Antagonism between invasive pest corals Tubastraea spp. and the native reef-builder Mussismilia hispida in the southwest Atlantic. J Exp Mar Biol Ecol 449: 69-76

Fenner D, Banks K (2004) Orange cup coral Tubastraea coccinea invades Florida and the Flower Garden Banks, Northwestern Gulf of Mexico. Coral Reefs 23: 505-507

Ferreira CEL (2003) Non-indigenous corals at marginal sites. Coral Reefs 22: 498

Glynn PW, Colley SB, Maté JL, Cortés J, Guzman HM, Bailey RL, Feingold JS, Enochs IC (2008) Reproductive ecology of the azooxanthellate coral Tubastraea coccinea in the Equatorial Eastern Pacific: Part V. Dendrophylliidae. Mar Biol 153: 529-544

Gratwicke B, Speight MR (2005) The relationship between fish species richness, abundance and habitat complexity in a range of shallow tropical marine habitats. J Fish Biol 66: 650-66

Harrison S (1991) Local extinction in a metapopulation context: an empirical evaluation. Biol J Linnean Soc 42: 73-88

Hennessey SM, Sammarco PW (2014) Competition for space in two invasive Indo-Pacific corals - Tubastraea micranthus and Tubastraea coccinea: Laboratory experimentation. J Exp Mar Biol Ecol 459: 144-150

Hubbel SP (1997) A unified theory of biogeography and relative species abundance and its application to tropical rain forests and coral reefs. Coral Reefs 16, Suppl: S9-S21

Idjadi JA, Karlson RH (2007) Spatial Arrangement of Competitors Influences Coexistence of Reef-Building Corals. Ecology 88 (10): 2449-2454

Lages BG, Fleury BG, Ferreira CEL, Pereira RC (2006) Chemical defense of an exotic coral as invasion strategy. J Exp Mar Biol Ecol 328: 127-135

Lages BG, Fleury BG, Pinto AC, Creed JC (2010) Chemical defenses against generalist fish predators and fouling organisms in two invasive ahermatypic corals in the genus Tubastraea. Mar Ecol 31: 473-482

Lages BG, Fleury BG, Menegola C, Creed JC (2011) Change in tropical rocky shore communities due to an alien coral invasion. Mar Ecol Prog Ser 438: 85-96

Lapid Ed, Wielgus J, Chadwick-Furman NE (2004) Sweeper tentacles of the brain coral Platygyra daedalea: induced development and effects on competitors. Mar Ecol Prog Ser 282: 161-171

Lenz M, Da Gama BAP, Gerner NV, Gobin J, Gröner F, Harry A, Jenkins SR, Kraufvelin P, Mummelthei C, Sareyka J, Xavier EA, Wahl M (2011) Non-native marine invertebrates are more tolerant towards environmental stress than taxonomically related native species: Results from a globally replicated study. Environ Res 111: $943-952$

Lopes RM (2009) Informe sobre as espécies exóticas invasoras marinhas no Brasil. Ministério do Meio Ambiente, Curitiba, SC, Brazil

Lubchenco J (1980) Algal zonation in the New England rocky intertidal community - an experimental analysis. Ecology 61: 333-344

Luz BPL, Kitahara MV (2017) Could the invasive scleractinians Tubastraea coccinea and T. tagusensis replace the dominant zoantharian Palythoa caribaeorum in the Brazilian subtidal? Coral Reefs 36: 875 
Luz BLP, Capel KCC, Zilberberg C, Flores AAV, Migotto AE, Kitahara MV (2018) A polyp from nothing: The extreme regeneration capacity of the Atlantic invasive sun corals Tubastraea coccinea and $T$. tagusensis (Anthozoa, Scleractinia). J Exp Mar Biol Ecol 503: 60-65

Mangelli TS, Creed JC (2012) Análise comparativa da abundância do coral invasor Tubastraea spp. (Cnidaria, Anthozoa) em substratos naturais e artificiais na Ilha Grande, Rio de Janeiro, Brasil. Iheringia, Série Zoologia 102(2): 122-130

Mantelatto MC, Creed JC, Mourão GG, Migotto AE, Lindner A (2011) Range expansion of the invasive corals Tubastraea coccinea and Tubastraea tagusensis in the Southwest Atlantic. Coral Reefs 30: 397

Mantelatto MC (2012) Distribuição e abundância do coral invasor Tubastraea spp. Msc dissertation, Universidade do Estado do Rio de Janeiro, Rio de Janeiro, RJ, Brazil

Menge BA (1976) Organization of the New England rocky intertidal community: role of predation, competition, and environmental heterogeneity. Ecol Monogr 46: 355-393

Mizrahi D, Navarrete AS, Flores AAV (2014) Groups travel further: pelagic metamorphosis and polyp clustering allow higher dispersal potential in sun coral propagules? Coral Reefs 33: 443-448

Mizrahi D, Pereira SF, Navarrete AS, Flores AAV (2017) Allelopathic effects on the sun-coral invasion: facilitation, inhibition and patterns of local biodiversity. Mar Biol 164: 139

Moreira TSG, Creed JC (2012) Invasive, non-indigenous corals in a tropical rocky shore environment: No evidence for generalist predation. J Exper Mar Biol Ecol 438:7-13

Sale PF (1978) Coexistence of coral reef fishes - a lottery for living space. Env Biol Fish 3 (1): 85-102

Sammarco PW, Coll JC, La Barre S, Willis B (1983) Competitive Strategies of Soft Corals (Coelenterata: Octocorallia): Allelopathic Effects on Selected Scleractinian Corals. Coral Reefs 1: 173-178

Sammarco PW, Porter SA, Sinclair J, Genazzio M (2013) Depth distribution of a new invasive coral (Gulf of Mexico) - Tubastraea micranthus, comparisons with T. coccinea, and implications for control. Manag Biol Invas 4 (4): 291-303

Sammarco PW, Porter SA, Genazzio M, Sinclair J (2015) Success in Competition for Space in Two Invasive Coral Species in the western Atlantic - Tubastraea micranthus and T. coccinea. PLoS ONE 10(12): e0144581

Sampaio CLS, Miranda RJ, Maia-Nogueira R, de Anchieta CC, Nunes J (2012) New occurrences of the nonindigenous orange cup corals Tubastraea coccinea and T. tagusensis (Scleractinia: Dendrophylliidae) in Southwestern Atlantic. Check List 8: 528-530

Sheppard CRC (1982) Coral Populations on Reef Slopes and Their Major Controls. Mar Ecol Prog Ser 7: 83-115

Shinen JL, Navarrete SA. (2010) Coexistence and intertidal zonation of chthamalid barnacles along central Chile: Interference competition or a lottery for space? J Exp Mar Bio Ecol 392: 176-187

Shinen JL, Navarrete SA. (2014) Lottery Coexistence on Rocky Shores: Weak Niche Differentiation or Equal Competitors Engaged in Neutral Dynamics? Am Nat 183: 342-362

Silva R, Vinagre C, Kitahara MV, Acorsi I, Mizrahi D, Flores AAV (2019) Sun coral invasion of shallow rocky reefs: effects on mobile invertebrate assemblages in Southeastern Brazil. Biol Invasions 21 (4): 13391350

Soares MO, Davis M, Carneiro PBM (2018). Northward range expansion of the invasive coral (Tubastraea tagusensis) in the Southwestern Atlantic. Mar Biodiv 48: 1651-1654 
Tanner JE (1997) Interspecific competition reduces fitness in scleractinian corals. J Exp Mar Biol Ecol 214: 1934

Vermeij, MJA (2006) Early life-history dynamics of Caribbean coral species on artificial substratum: the importance of competition, growth and variation in life-history strategy. Coral Reefs 25: 59-71

Vieira EA, Flores AAV, Dias GM (2018a) Persistence and space preemption explain species-specific founder effects on the organization of marine sessile communities. Ecol Evol 8: 3430-3442

Vieira EA, Flores AAV, Dias GM (2018b) Adding early-stage engineering species affects advanced stage organization of shallow-water fouling assemblages. Hydrobiol 818: 211-222

Wells JW (1982) Notes on Indo-Pacific Scleractinian Corals. Part 9. New Corals from the Galapagos Islands. Pac Sci 36: 211-219 


\section{Chapter 2: INVASIVE SUN CORALS AND WARMING POSE INDEPENDENT THREATS TO THE BRAIN CORAL MUSSISMILIA HISPIDA IN THE SOUTHWESTERN ATLANTIC}

Barbosa, A. C. C.; Vinagre, C.; Mizrahi, D.; Duarte, R.C.; Flores, A. A. V.

Abstract - Sun corals Tubastraea tagusensis have invaded reef habitats from Florida to Southern Brazil, negatively impacting native habitat-forming species, including the most abundant scleractinian in Southeastern Brazil; the brain coral Mussismilia hispida. We combined field and laboratory experiments to closely evaluate the interaction between these corals at a range of temperature conditions. Field experiments undertaken during winter and late summer-fall aimed to test species interactions under current temperature regimes. When in contact with sun corals, all brain corals suffered necrosis, consuming 8 to $12 \%$ of whole-colony surfaces per month. Their growth rates were also lower compared to stand-alone control colonies $\left(-0.17\right.$ vs $1.23 \mathrm{~cm}^{2}$. month $\left.{ }^{-1}\right)$. Necrosis was never observed in sun corals and average growth rates $\left(0.36 \mathrm{~cm}^{2}\right.$. month-1) did not differ between interacting and isolated colonies. No season effects were detected for any of the coral traits examined. Negative effects of sun corals were further investigated in the laboratory both at current winter $\left(23^{\circ} \mathrm{C}\right)$ and summer average temperatures $\left(26^{\circ} \mathrm{C}\right)$, as well as extreme low $\left(20^{\circ} \mathrm{C}\right)$ and high $\left(29^{\circ} \mathrm{C}\right)$ temperature conditions that might persist for long periods under a climate-change scenario. Results suggest that species interactions may remain unaffected by climate change. Temperature effects were important but independent on whether brain corals were held isolated or in contact with sun corals. Interestingly, brain corals performed better at $20^{\circ} \mathrm{C}$, with most colonies remaining undamaged over 95 days. Sea-temperature 
rising and the increasing abundance of sun corals may thus be viewed as independent drivers potentially impacting brain coral populations and their associated assemblages.

Key words: biological invasions; global warming; interference competition; chemical ecology; Southeastern Brazil; rocky reefs 


\section{INTRODUCTION}

Sun corals, Tubastraea spp., have been recognized as alien and invasive species in the South Atlantic Ocean (e.g. Ferreira 2003, Fenner \& Banks 2004, De Paula \& Creed 2004). Native to the Indo-Pacific Ocean, they were first reported in Southeast Brazil in the late 80 's, colonizing oil and gas platforms in the Campos Basin (Castro \& Pires 2001). More recently they have expanded to numerous sites along the Brazilian coast, spanning from north to south the states of Ceará (Soares et al. 2018), Bahia (Sampaio et al. 2012, Creed et al. 2016), Rio de Janeiro (De Paula \& Creed 2005, Creed et al. 2016), São Paulo (Mantelatto et al. 2011, Creed et al. 2016) and Santa Catarina (Lopes 2009, Creed et al. 2016). The "invasive" status of sun corals (Global Invasive Species Database, www.invasivespecies.net) is largely due to their high growth rates (Vermeij 2006), early maturation (Glynn et al. 2008) and high regeneration capacity (Luz et al. 2018). Adult colonies have also the ability to reproduce sexually and asexually (Campbell 1983). Planula larvae can metamorphose into planktonic polyps allowing an extended pelagic phase and thus increase their dispersal potential (Mizrahi et al. 2014a). Because artificial substrates are often colonized first (Creed \& De Paula 2007), harbors, marinas and other coastal facilities built along coastlines may constitute stepping stones holding large reproducing coral populations, while floating oil platforms and commercial vessels may greatly enhance the connectivity among such populations and deliver propagule pressure on still uninvaded reefs.

Once established, the biological interactions of sun corals with pre-established assemblages may lead to reduced reef biodiversity and profound alterations of wholeecosystem functioning. There is evidence of their competitive dominance over native corals (Creed 2006, dos Santos et al. 2013) and their capacity to inhibit recruitment of other species through negative allelopathic interactions (Lages et al. 2006, 2011). Moreover, sun 
corals can cope with substantial environmental change (Lenz et al. 2011) and lack any known natural predators in the Southwest Atlantic (Lages et al. 2010). Probably combined, all these characteristics may have contributed to the present-day generalized dominance of sun-corals at sites where first colonization backs to a decade or more. At some sites from northern São Paulo to southern Rio de Janeiro states, sun-corals almost saturate space at patches several tens to a few hundred meters long, especially on vertical walls (e.g. Creed 2006, Creed \& De Paula 2007, Lages et al. 2011, 2012, Silva et al. 2019). Besides the exclusion of several fouling species (Mizrahi et al. 2017), sun corals reengineer reef space and may indirectly cause the near collapse of important components of mobile invertebrate assemblages (Silva et al. 2019).

Still, there is at present no information on the potential effects of climate change on the invasive dynamics of sun corals along the Southwestern Atlantic. Understanding the outcomes of species interactions under alternative climate scenarios in this region is very important, as long it will support any predictions on how stable sun coral populations will be in its current invasive range, as well as anticipating any range shifts, chiefly towards southern, presently warm-temperate regions. We tackle this issue by examining competitive interactions between the yellow sun coral Tubastraea tagusensis Wells, 1982 and the most abundant native scleractinian in Southeastern Brazil, the brain coral Mussismilia hispida (Verrill, 1902) (a species endemic to Brazilian coastal waters; OigmanPszczol et al. 2004), at different temperature conditions. Previous studies showed that sun corals may cause tissue necrosis on $M$. hispida, suggesting a competitive advantage for the alien species (Creed 2006), and predicted widespread, strong declines of the native species M. hispida as a result of the broad environmental overlap between brain corals and the sun coral Tubastraea coccinea (as estimated by species distribution modelling, Riul et al. 2013). 
Yet, experimental evidence for the outcomes of sun vs brain coral interactions at different thermal regimes is still lacking.

In this study, we carried out field experiments to examine the interactions between Tubastraea tagusensis and Mussismilia hispida, during summer-fall and winter, to test any seasonal trends of the outcome of coral-coral interactions, and then extended the approach in the laboratory to obtain not only independent evidence of interactions at present-day thermal conditions, but also at far ranging extremes (warm and cold) that may frequently endure for long periods by 2100 (Brazilian Panel on Climate Change, PBMC 2012; Intergovernmental Panel on Climate Change, IPCC 2013). Historical averages of sea surface temperature (www.seatemperature.org) at the native geographic area of $T$. tagusensis (Galapagos) largely overlap the ones observed at the area we conducted this study (Ilhabela, SP, Brazil, Fig. 1), where both this sun coral species and the brain coral M. hispida are abundant. Nevertheless, Ilhabela is close to the southern range limit of brain corals, which extends northwards up to Maranhão (northern Brazil, Zilberberg et al. 2014), where average temperatures are much higher (Fig. 1). Even when locally coexistent, the thermal niche of sun corals Tubastraea spp., as a whole, should also be different at some extent from that of the brain coral M. hispida, as long as they do not host symbiont zooxanthellae and tend to be distributed at reef habitats with lower light intensity, over vertical and negative surfaces (Mizrahi et al. 2014b) and at greater depth, where temperature may be considerable lower. Thus, we predicted that the outcome of competitive interactions between $M$. hispida and T. tagusensis would be less detrimental for the former species in a warming scenario. 


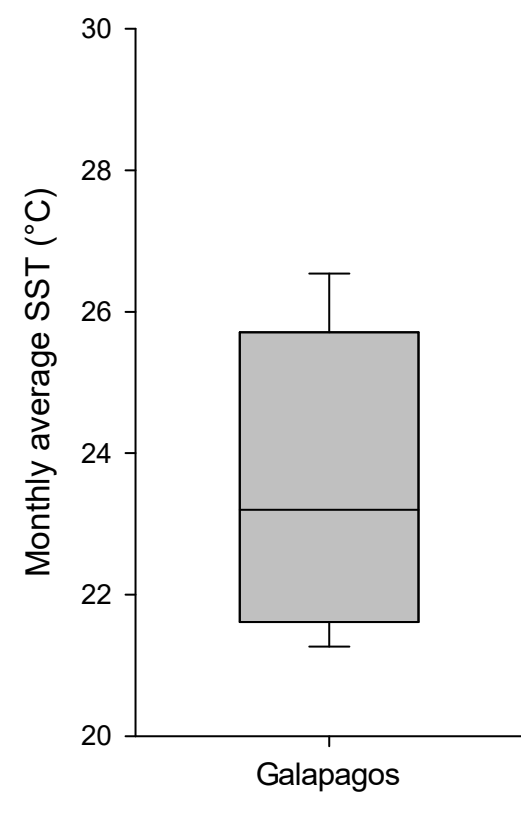

Tubastraea tagusensis
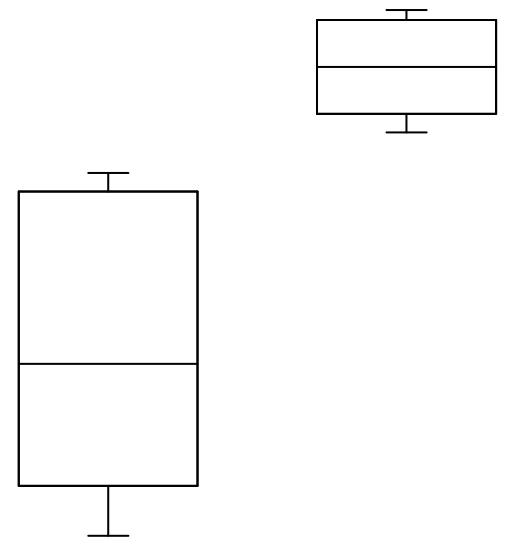

Ilhabela, SP São Luis, MA

Mussismilia hispida

Figure 1. Box-and-whisker plots, showing $10^{\text {th }}, 50^{\text {th }}$ and $90^{\text {th }}$ percentiles, of monthly sea-surface temperature averages (covering a period of over $100 \mathrm{yr}$, www.seatemperature.org) of Tubastraea tagusensis and Mussismilia hispida at native areas. Sun corals T. tagusensis were originally restricted to Galapagos (left), and M. hispida, while endemic to the Brazilian coast, are distributed from São Paulo State, close to our study area (Ilhabela), to Maranhão State (São Luis, right).

\section{MATERIAL AND METHODS}

\section{Seasonal interactions in nature}

\section{Fieldwork}

Coral performance was assessed at Búzios Island, $25 \mathrm{~km}$ off the coast of São Paulo state, Brazil, during 2017 summer-fall (from Jan $26^{\text {th }}$ to May $5^{\text {th }}$ ) and winter (from Jun $13^{\text {th }}$ to Sep $\left.19^{\text {th }}\right)$, over 98 days each season. We compared coral performance when colonies were held isolated or in heterospecific pairs. Through scuba diving, small Tubastraea tagusensis $\left(\mathrm{T} ; 33.1 \pm 17.4 \mathrm{~cm}^{2}\right)$ and Mussismilia hispida $\left(\mathrm{M} ; 70.6 \pm 45.8 \mathrm{~cm}^{2}\right)$ colonies were 
removed using hammer and chisel and then randomly fixed with epoxy cement (Tubolit ${ }^{\circledR}$ ) to nearby new sites at the same depth $(7-10 \mathrm{~m})$ and substrate orientation (nearly horizontal), and identified with numbered plastic tags. The whole experiment was conducted within an area of nearly $150 \mathrm{~m}^{2}$. Five treatments were applied to each coral species: (i) single colonies were either transplanted and held isolated (Tt, Mt), (ii) transplanted to the side of a heterospecific colony, allowing physical contact by moving $T$. tagusensis (MTt) or (iii) M. hispida (TMt), (iv) not transplanted but otherwise in contact with the epoxy cement to control for any possible effects of this material on coral performance (Te, Me), and finally ( $v$ ) control colonies, naturally found isolated and left untouched (Tc, Mc). Sample size in each treatment was seven. In all cases, the rock surface around colonies (ca. $5 \mathrm{~cm}$ ) was scraped off to minimize any effects of other sessile organisms on corals. All experimental colonies were photographed every 10 to 20 days, depending on weather conditions, comprising eight sampling dates for the summer-fall season and seven dates for the winter season. Images were then processed to estimate rates of colony growth (as increments of basal area; $\mathrm{cm}^{2} \cdot \mathrm{month}^{-1}$ ) and tissue necrosis (percent.month $^{-1}$ ) using the software Image $1.50 \mathrm{~b}$ (Schneider et al. 2012) (http://imagej.nih.gov/ij/index.html), as well as to spot the first appearance of turf filamentous algae over the damaged coral surface. Temperature was recorded every two hours over the two sampling seasons with i-button ${ }^{\circledR}$ loggers.

\section{Statistical analyses}

For each focal replicate colony of either Tubastraea tagusensis or Mussismilia hispida estimates of percent tissue necrosis and growth were obtained by regressing these variables against time (thus providing monthly rates of change). Two-way factorial GLMs 
were used to test any contrasts of necrosis and growth rates according to 'treatment' (as explained above) and 'season' (summer-fall vs winter), both considered fixed factors. Growth data for both species were heteroscedastic and remained so after logtransformation. GLMs were still used in these cases as sampling size is sufficiently large and the analysis is balanced (Underwood 1996). After obtaining omnibus mean-square error estimates for overall treatment effects, we proceeded to planned comparisons testing for (i) artifact epoxy effects (control vs cemented colonies), (ii) artifact transplant effects (cemented colonies vs cemented colonies transplanted elsewhere), (iii) overall effects of species contact interactions (stand-alone vs interacting colonies), (iv) status-specific effects of contact interactions (interacting transplanted vs interacting non-transplanted colonies). Necrosis was only observed in interacting brain corals, and therefore contrasts were restricted to iv, at both seasons. In this case, the SNK procedure was used for post-hoc pairwise comparisons. The proportion of damaged colonies overgrown by turf algae was compared between seasons using a two-tailed z-test.

Interactions at average and extreme temperature conditions in the laboratory

\section{Laboratory work}

Small colonies of the sun coral Tubastraea tagusensis (maximum diameter $3.7 \pm 0.5$ $\mathrm{cm}$ ) and the brain coral Mussismilia hispida (maximum diameter $5.0 \pm 1.2 \mathrm{~cm}$ ) were collected in November 2016 at Búzios Island and brought to the Centre for Marine Biology, University of São Paulo (CEBIMar - USP). All attached organisms were removed with tweezers and then coral colonies were acclimated for 2 months in indoor $500 \mathrm{~L}$ tanks provided running seawater pumped from a nearshore inlet, with no temperature control (average daily minimum and maximum temperature: $22.1 \pm 1.9^{\circ} \mathrm{C}$ and $26.6 \pm 2.8^{\circ} \mathrm{C}$ ). 
We examined the performance of individual brain coral colonies over four months (from Feb $1^{\text {st }}$ to May $8^{\text {th }} 2017$ ), either alone or in heterospecific pairs (allowing physical contact between colonies), across different temperature regimes based on historical monthly averages and annual warming rates calculated by Valentim et al (2013), and temperature extreme events (both warming and cooling) expected in our study region by 2100 (PBMC 2012, IPCC 2013). In order to maintain temperature regimes as close as possible to target ranges, we set the room temperature to $25^{\circ} \mathrm{C}$, while maintaining a natural photoperiod (12L/12D), and used chillers or heaters to adjust the temperature to treatment specifications in four $150 \mathrm{~L}$ reservoir tanks that supplied experimental units. We were able to set conditions closely matching the (i) average current winter temperature (treatment ' $\mathrm{C}$ '; $23.3 \pm 2.5^{\circ} \mathrm{C}$ ), (ii) the average current summer temperature (treatment ' $\mathrm{H}$ '; $26.3 \pm 1.8^{\circ} \mathrm{C}$ ), and the temperature compatible to (iii) winter cold fronts (treatment ' $\mathrm{C}-{ }^{\prime}$; $20.3 \pm 1.8^{\circ} \mathrm{C}$ ), and (iv) summer heat waves (treatment ' $\mathrm{H}+^{\prime} ; 29.3 \pm 2.5^{\circ} \mathrm{C}$ ), which are expected to be more prolonged and frequent in the future.

A water pump constantly replenished reservoir tanks with filtered sea water (through a sequence of 100, 50 and $10 \mu \mathrm{m}$ meshes), and the water flow set to individual experimental tanks ( $1 \mathrm{~L}$ circular units; diameter: $14 \mathrm{~cm}$, height: $7.5 \mathrm{~cm}$ ) was approximately $1.0 \mathrm{~mL} . \mathrm{s}^{-1}$, allowing the water to be renewed 3-4 times each hour and the temperature to remain close to that of the source reservoir tank. For each temperature regime, five circular replicate tanks were used for two different treatments: $M$. hispida alone and $M$. hispida interacting with $T$. tagusensis. All coral colonies were randomly distributed in experimental treatment combinations and all tanks occupied random and shifting positions over working space. Every other day, corals were fed living plankton $(>150 \mu \mathrm{m})$ ad libitum and inspected for tissue necrosis or death (devoid of any living tissue). 


\section{Statistical analyses}

Survival analysis was used to examine damage rate, based on the time when necrosis was first observed for any given colony, across factors 'temperature' (C-, C, H, H+) and 'species interaction' (stand-alone vs interacting colonies). In some cases healthy colonies died over the next $2 \mathrm{~d}$ without intermediate tissue loss, and therefore damage rates combine necrosis and deaths. The Kaplan-Meier analysis (Taylor et al. 1958) was applied to obtain survival probabilities (i.e. the percentage of healthy colonies) of coral colonies from different experimental treatments over time. The Cox Proportional-Hazards Regression (Fox \& Weisberg 2011) was used to model and test the significance of the experimental factors on coral survival. This method assumes that the hazard of an event at a given time can be modeled by the product of a baseline hazard function and a regression function of tested covariates (Sinnot \& Cai 2016). Analyses were performed in the software R 3.2 using the functions survfit and coxph from the 'Survival' package.

\section{RESULTS}

\section{Seasonal interactions in nature}

In situ temperature regimes were strikingly different between the two sampled seasons. During the summer-fall period, temperatures varied more uniformly around a median value of $25.0^{\circ} \mathrm{C}$, while during winter the temperature distribution was clearly leftskewed, with a median value at $20.7^{\circ} \mathrm{C}$ and repeated observations near extreme low values (Fig. 2). Those are in general lower values than historical averages. During the warmer season, daily averages never reached the $29-30^{\circ} \mathrm{C}$ range at which native corals in the region start bleaching (Migotto 1997), and, notably, at the end of the cooler season temperature ranged between 16 and $18^{\circ} \mathrm{C}$ for half a month. Despite of the great difference 
between temperature regimes during the sampled seasons, there were no seasonal effects on none of the coral traits examined in this study, including the outcome of species interactions (Table 1, Fig. 2).
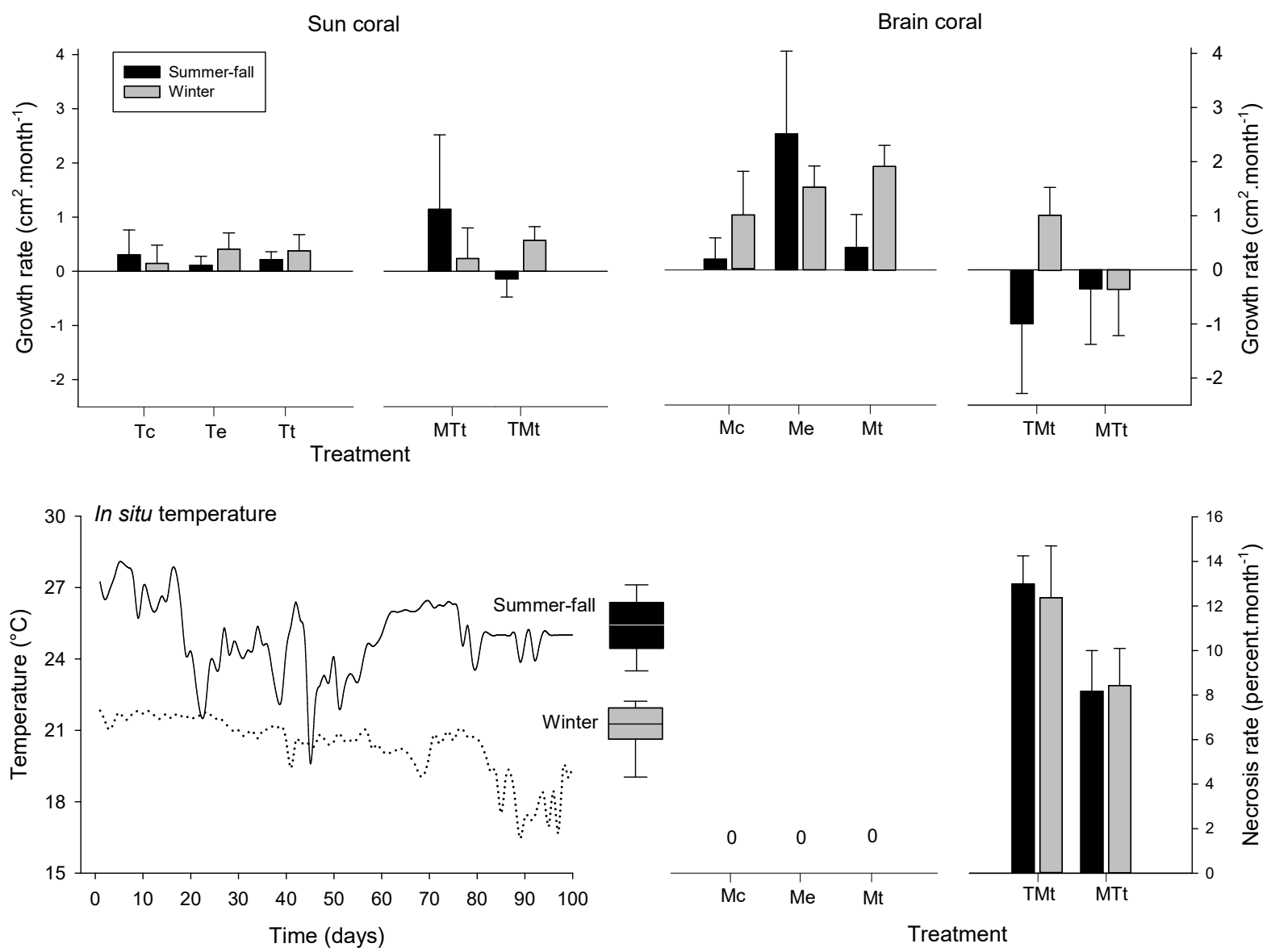

Figure 2. Results of the field experiment testing the outcomes of species interactions for both the invasive sun coral Tubastraea tagusensis $(T)$ and the native brain coral Mussismilia hispida $(M)$ in two different seasons. Treatments in which colonies were held isolated served both as controls (subscript c), and procedural controls for possible effects of epoxy cement (subscript $e$ ) and transplanting (subscript $t$ ), as well as a baseline for colony performance without interspecific contact interactions. TMt and MTt stand for interacting treatments in which the transplanted colonies were M. hispida and T. tagusensis, respectively. Error bars stand for + 1SE. Boxplots specifications representing the thermal conditions at the sampled seasons were the same as in figure 1 . 
Table 1. Summary results of 2-way GLMs testing seasonal effects of interspecific contact interactions (treatment) on sun and brain corals in the field (Ilha de Búzios, SP, Brazil). Response variables were growth (basal area) and the apparent area of tissue necrosis; the latter never observed in the sun coral Tubastraea tagusensis. $P$-values of significant sources of variation are shown in bold. $C$ stands for the Cochran statistic testing for variance heterogeneity.

\begin{tabular}{|c|c|c|c|c|c|c|c|c|}
\hline & \multirow[b]{3}{*}{$d f$} & \multicolumn{4}{|c|}{ Growth $\left(\mathrm{mm}^{2} \cdot\right.$ month $\left.^{-1}\right)$} & \multirow{2}{*}{\multicolumn{3}{|c|}{$\frac{\text { Necrosis }_{\left(\% . \text { month }^{-1}\right)}}{\text { Mussismilia }}$}} \\
\hline & & \multicolumn{2}{|c|}{ Tubastraea } & \multicolumn{2}{|c|}{ Mussismilia } & & & \\
\hline & & $F$ & $p$ & $F$ & $p$ & $d f$ & $F$ & $p$ \\
\hline Treatment & 4 & 0.23 & 0.920 & 2.61 & 0.044 & 1 & 5.79 & 0.024 \\
\hline Season & 1 & 0.00 & 0.987 & 2.26 & 0.138 & 1 & 0.01 & 0.919 \\
\hline $\mathrm{T} * \mathrm{~S}$ & 4 & 0.77 & 0.552 & 1.37 & 0.256 & 1 & 0.06 & 0.811 \\
\hline \multirow[t]{3}{*}{ Res } & 60 & & & & & 24 & & \\
\hline & & \multicolumn{2}{|c|}{ In-transformed } & \multicolumn{2}{|c|}{ In-transformed } & \multicolumn{3}{|c|}{ raw data } \\
\hline & & \multicolumn{2}{|c|}{$C=0.8056 ; p<0.01$} & \multicolumn{2}{|c|}{$C=0.3568 ; p<0.01$} & \multicolumn{3}{|c|}{$C=0.4144 ; p>0.05$} \\
\hline
\end{tabular}

Necrosis was never observed in sun corals Tubastraea tagusensis, and differences of growth rates among treatments, which included isolated and interacting colonies, were not significant (Table 1). Yet, responses were clearly more variable for the pool of the two interacting treatments [coefficient of variation $(\mathrm{CV})=48.4 \%$ ] compared to the pool of stand-alone treatments ( $\mathrm{CV}=39.2 \%$; Fig. 2 ), but still around the overall growth rate estimate $\left(0.36 \pm 0.16 \mathrm{~cm}^{2} \cdot\right.$ month $\left.^{-1}\right)$.

Differently, contact interactions with sun corals greatly affected growth rates and tissue necrosis in brain corals Mussismilia hispida (Table 1, Fig. 2). The growth rate estimate for overall stand-alone treatments (Mc, Me and Mt) was $1.26 \pm 4.6 \mathrm{~cm}^{2}$. month-1 (Fig. 2), and planned comparisons evidenced no artifact effects of contact with epoxy cement (Mc vs Me; $F=2.75, p=0.102$ ), nor any artifacts owing to the transplantation procedure itself (Me vs Mt; $F=0.96, p=0.329$ ). Growth rates, however, greatly decreased when colonies were held in contact with the sun coral $\left(-0.17 \pm 6.21 \mathrm{~cm}^{2} \cdot \mathrm{month}^{-1}\right.$; Fig. 2), with the 
respective planned contrast indicating this is a significant difference (Mc-Me-Mt vs MTtTMt; $F=6.55, p=0.013)$. There was no apparent relevance on whether the transplanted species was $M$. hispida or T. tagusensis (TMt vs MTt; $F=1.62, p=0.208$; Fig. 2). Growth responses were generally more variable for $M$. hispida compared to $T$. tagusensis, with no substantial differences for stand-alone brain corals ( $C V=55.8 \%)$ and interacting individuals $(\mathrm{CV}=56.4 \%)$. Tissue necrosis was never detected for isolated brain coral colonies but was observed for all individuals in contact with sun corals. In contrast to growth rates, necrosis rate depended on the transplanted coral species (Table 1). Transplanted brain corals to the vicinity of a sun coral colony suffered higher necrosis rates than brain corals in contact with a transplanted sun-coral colony (12 and $8 \%$ tissue loss each month, respectively; Fig. 2). After necrosis, bare coral skeleton was frequently overgrown by filamentous turf algae at some point during the experiment (Fig. 3). The proportion of damaged colonies covered by algal turf was however higher during winter-fall (0.93), compared to summer $(0.57 ; z=2.18$, $p=0.015)$. 


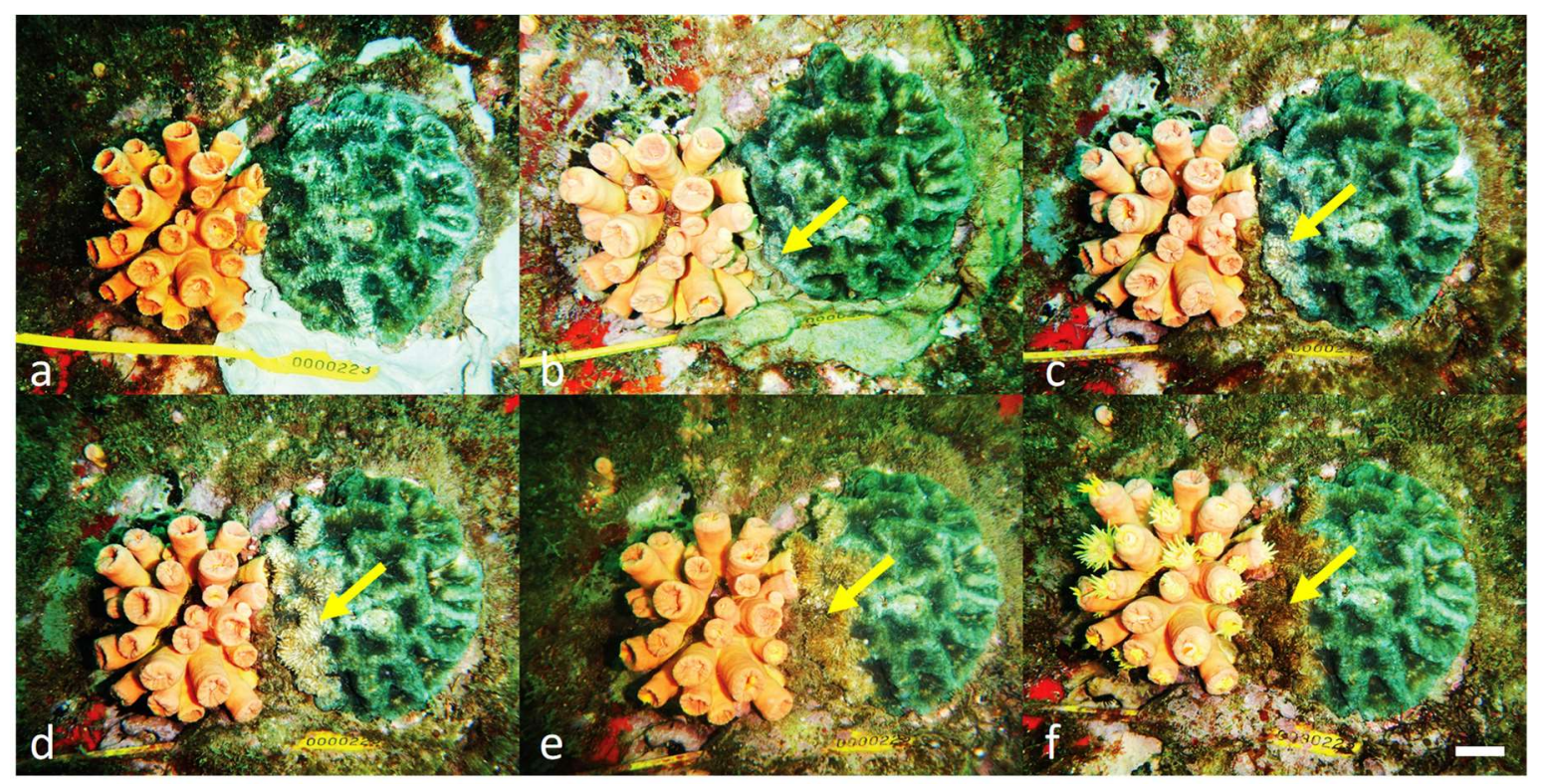

Figure 3. Temporal change of a transplanted brain coral colony in contact with a pre-established sun coral colony during winter. Yellow arrows point to necrosed brain coral tissue from (c) onwards. Note a conspicuous cover of filamentous green algae over dead coral areas on pictures e - $f$. (a) Day 0 , (b) day 13 , (c) day 29 , (d) day 43, (e) day 56 , (f) day 77 . The scale bar represents $2.5 \mathrm{~cm}$.

\section{Interactions at average and extreme temperature conditions in the laboratory}

Survival analyses indicated that damage rate on brain corals depended on both the temperature regime and whether or not colonies were held alone or in contact interaction with sun corals (Table 2, Fig. 4). Only main effects were detected - not the interaction between the two factors. Hence, the initial prediction that damage rates through contact interactions would be reduced at higher temperatures finds no support. In fact, regardless of the interaction status, brain corals performed better at the coldest temperature regime $\left(20^{\circ} \mathrm{C}\right.$; Fig. 4), compatible to the unusual cold season we sampled in the field and a more likely scenario during future cold fronts. Of the 10 colonies held in this treatment, 6 remained undamaged until the end of the experiment ( $95 \mathrm{~d}$ ), of which 3 were isolated and 3 were interacting individuals. Brain coral performance at all the other temperature treatments was similar, with undamaged colonies making up only $10-20 \%$ of initial stocks 
by day 20. The overall effect of contact interactions is clear (Table 2); decay curves never crossed over time and at the end of the experiment the proportion of undamaged colonies was $35 \%$ for isolated individuals and only $15 \%$ for colonies maintained in contact with the sun coral (Fig. 4).

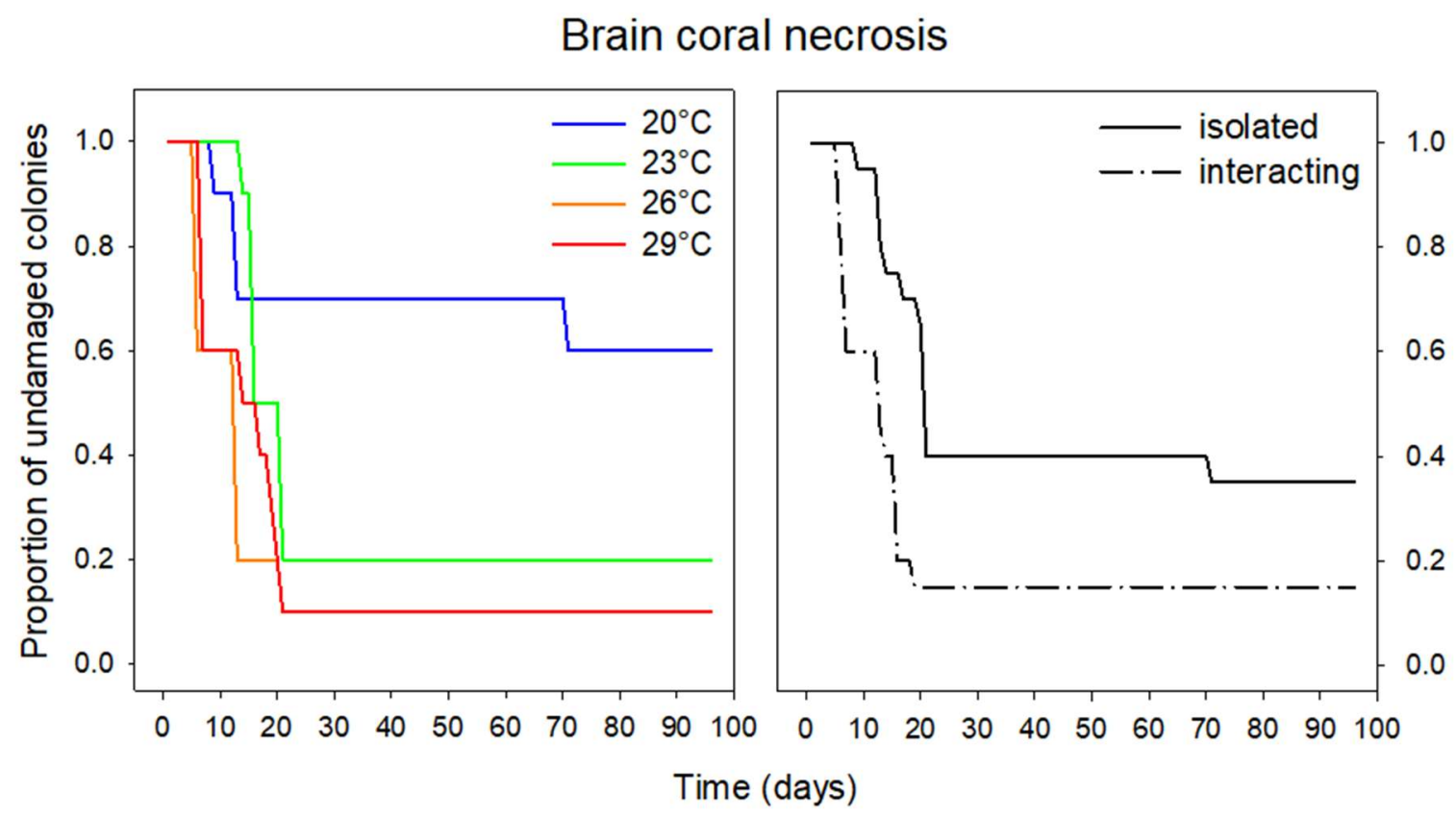

Figure 4. Result of survival analysis showing the decay of the proportion of undamaged brain coral colonies according to temperature and whether or not colonies were placed in contact with a sun coral colony.

Table 2. Survival analysis results on Mussismilia hispida damage rates. The interaction between factors 'temperature' and 'coral interaction' was not significant $(p>0.05)$.

\begin{tabular}{lccc}
\hline \multicolumn{4}{c}{ Musssimilia hispida necrosis } \\
\hline & Hazard rate & Z & $p$ \\
\cline { 2 - 4 } Temperature & 1.8113 & 3.556 & $\mathbf{0 . 0 0 0 4}$ \\
Coral interaction & 4.1023 & 3.453 & $\mathbf{0 . 0 0 0 6}$ \\
\hline
\end{tabular}


DISCUSSION

Competition for space is often cited as a major mechanism influencing the structure of hard-bottom benthic ecosystems (Menge 1976, Lubchenco 1980), including coral reefs (Lang \& Chornesky 1990, Karlson 1999). Negative interspecific interactions between corals are frequent, and competing individuals often experience reduced growth rates (Sammarco et al. 1983, Tanner 1997) or damage through direct interference (Lapid et al. 2004, Hennessey \& Sammarco 2014). When in equilibrium, coral interactions combined with environmental change may actually promote whole-reef diversity, either through reciprocal interaction outcomes between species with similar competition capacity, or through disturbance-mediated declines of superior competitors, which provide the opportunity for the establishment of several different species that would be otherwise absent (Connell 1976, Porter et al. 1981, Connell et al. 2004). Our results, however, indicate that contact interactions between sun and native brain corals, presently the most important scleractinians along the subtropical Southwest Atlantic, may further contribute to the impoverishment of reef systems owing to the dominance of invasive sun corals Tubastraea spp. In this non-equilibrium state, species traits challenge the traditional view (Connell 1976) that high growth rates are characteristic of strong competitors and that the capacity to deter neighboring heterospecifics, either through extra-coelenteric digestion (Lang 1973) or negative allelopathy (Sammarco et al. 1983), is a defensive response of weak competitors. Here, we showed that stand-alone $M$. hispida colonies are capable of much higher growth rates than isolated $T$. tagusensis colonies, and that negative contact effects are restricted to those of $T$. tagusensis on M. hispida, never the other way around. Still, we regard sun corals as the competitive superior species because effects on brain corals are not limited to tissue necrosis (and thus defense) but also affect growth potential. 
Regardless of season, overall growth rates of brain corals turned negative $(-0.16$ $\mathrm{cm}^{2}$.month ${ }^{-1}$ ) and necrosis ranged between 8 and $12 \%$ when in contact with sun corals. Although varying in a relatively narrow range, necrosis estimates should be interpreted carefully because the identity of the transplanted species mattered. Since the overall abundance of sun corals is increasing everywhere in the region, and because sun corals strongly inhibit the settlement of other fouling invertebrates nearby (Lages et al. 2010), potential necrosis rates upon contact may be probably closer to the lower estimate (c.a. 8\%), obtained for contact interactions in which T. tagusensis was the transplanted species. Even so, tissue necrosis and reduced growth combined would lead to death of $M$. hispida colonies in less than a year, regardless of season, assuming that the estimated rates will hold until total tissue necrosis. Of course, these results are only applicable to small brain coral colonies within the size used in this study. Other things being equal, larger colonies would suffer lower tissue damage, as observed for M. hispida interacting with macroalgae (Ferrari et al. 2012) and zoanthids (Cruz et al. 2016).

It is interesting to note, however, that growth rates of interacting colonies of both brain and sun corals are highly variable, in the case of the latter species contrasting with the markedly uniform growth rate observed for stand-alone treatments. Such plastic responses introduce some degree of uncertainty on the long-term effects of heterospecific contact interactions. There is considerable debate on whether adaptive evolution is restrained (through genotype 'shielding') or facilitated (through genetic 'assimilation' of adaptive phenotypes) by trait plasticity (Price et al. 2003, Ghalambor et al. 2007), but relative consensus that genetic variation may underlie faster directional selection towards the 'optimal' phenotype upon environmental change (e.g. Rainey \& Travisano 1998, Barrett \& Schluter 2008). Contact interactions between sun and brain corals constitute a novel 
situation for both species, and, thus, whether or not there is room for adaptive evolution to a favorable phenotype (i.e. resistant to contact with heterospecific corals) becomes a relevant question. Present-day average outcomes suggest a very negative scenario for brain corals, but strong genetic structure along the Southwest Atlantic (Peluso et al. 2018), coupled to the highly variable growth response of interacting individuals, suggest there is potential for selection of more resistant genotypes. Differently, prevailing asexual reproduction with high proportion of clones and lack of genetic structure along the invaded region (Capel et al. 2017) suggests there is virtually no room for genetically based improvements of the competitive ability of sun corals in the future. As such, we speculate that brain corals may be eventually better defended against sun-coral contact interactions in the long-term. Brain coral colonies capable to hold control-like growth rates, as observed for some individuals in winter for the TMt treatment, may have some extra time to spawn before tissue necrosis advance to a critical extent, and therefore reduce negative indirect impacts on propagule production and recruitment.

The lack of detectable seasonal effects suggests that present-day temperature variation is insufficient to modulate the outcome of interactions between sun and brain corals. Namely, departures from eventual temperature optima for these two species would not underlie, nowadays, any apparent arms-race on the capacity of sun corals to directly damage neighbor brain corals or the ability of the latter to recover. Interestingly, overgrowth of necrosed Mussismilia tissues by filamentous algae was very common and could have played an indirect but important role on the mediation of direct coral interactions. McCook and co-workers (2001) reviewed the experimental work examining the interaction between corals and the algae overgrowing them and found that the few studies allowing a proper test for cause-effect relationships provided different conclusions. 
There is general agreement that algae do not cause tissue damage or bleaching in the first place, but rather use inert coral surface opportunistically. Once established, however, most studies did report negative effects of algae on their host corals (shading, abrasion or smothering causing reduced growth, reproductive output or even death), but some work revealed neutral effects. For instance, mixed-species algal turf, preventing the proliferation of a harmful red filamentous alga, causes no measurable effects on massive Porites spp. (Jompa \& McCook 2003), even along a gradient of terrestrial inputs that could have increased turf dominance and competitive superiority (McCook 2001). In our study region, the concentration of nutrients in the water column is usually markedly low (Flores et al. 2015), but higher nutrient concentration owing to vertical mixing during the passage of cold fronts may increase primary production in wintertime (Ciotti et al. 2010). The seasonal trend of primary production could explain why nearly all damaged brain coral colonies were overgrown by filamentous algal turfs in winter, but only $57 \%$ during summer-fall. Considering the evidence so far, we would thus expect a much worse performance of damaged colonies in winter compared to summer-fall, but no seasonal effects were detected. As such, our result is aligned to the fewer studies suggesting null effects of overgrowing algal turfs. At this stage, it is difficult to identify the mechanisms cancelling out any stresses that overgrowing algae may impose to corals at the edge between necrosed and living tissues, but it is possible that filamentous turf growing at the contact zone between corals (as experimental nylon mesh screens; dos Santos et al. 2013) may actually protect $M$. hispida from further aggression. Further experimental work is needed to tease apart the effects of these and other possible mechanisms controlling the performance of interacting brain corals in the field. 
Contrasting with field results, laboratory trials testing effects at average and extreme conditions showed that temperature may play an important role on the damaging rate of brain corals, independently of contact interactions. We hypothesized that heterospecific interactions would be less detrimental to brain corals in warmer conditions, because they are found over a wide latitudinal range, expanding to warmer-water ecoregions, but over a short depth range, restricted to well-lit shallow reef habitats where the temperature is higher. Results, however, do not support this prediction. In fact, regardless of whether or not individuals were held in contact with a heterospecific, brain coral colonies did worse, not better, at temperatures above $25^{\circ} \mathrm{C}$, similarly to the congener Mussismilia harttii, which suffers tissue necrosis at temperatures between 26.5 and $35.0^{\circ} \mathrm{C}$ (Winter et al. 2016). Interestingly, at the coolest temperature treatment, around $20^{\circ} \mathrm{C}, 60 \%$ of $M$. hispida colonies remained undamaged at the end of the experiment, even when in contact with the sun coral $(n=3)$. While this result suggests that brain corals would be particularly resistant over prolonged periods of cool water, extrapolations to natural conditions should be addressed with caution, as long as all interacting brain colonies necrosed in the field, with no exception, during both summer-fall and winter. Clearly, other environmental variables not controlled in the laboratory mediate the outcomes of interspecific coral interactions in nature. Still, it is noteworthy that at Arraial do Cabo, RJ, an area prone to extensive upwelling, sun coral colonies and recruits become less abundant at sites where the average temperature is lower than $20^{\circ} \mathrm{C}$ (Batista et al. 2017). Since thermal conditions are favorable and competition with sun-corals relieved, brain corals may thus thrive at upwelling spots such as those. In contrast, the ongoing warming of most coastlines along the Southwest Atlantic will likely impact brain corals the most. Unlike sun corals, $M$. hispida relies on the primary production of zooxanthellae which are very 
susceptible to warming (Hoegh-Guldberg 1999). Prolonged warming to ca. $1^{\circ} \mathrm{C}$ over maximum average summer temperature typically causes the photo-inhibition of zooxanthellae, their death and ultimately coral bleaching (Hughes et al. 2003), which might have caused the exceedingly high damage rate observed for brain corals in the $29^{\circ} \mathrm{C}$ treatment. Tissue necrosis and bleaching would therefore contribute to decrease braincoral but not sun-coral populations, ultimately ceding space for the invasive species.

The brain coral Mussismilia hispida is not only the most important native scleractinian in the study region, but also a host for more than 130 different invertebrates, comprising mobile, fouling and endolithic species, some of those using this biogenic habitat as a nursery ground (Nogueira 2003). Severe declines of brain coral populations may not only negatively impact biological diversity, but also ecosystem functioning, as long as the replacement of autotrophic brain corals by heterotrophic sun corals may profoundly alter food webs (Mantelatto 2012). At reef habitats where the invasion history is still recent, heavy sun coral colonization is almost restricted to preferred vertical surfaces (Mizrahi et al. 2014b), and therefore brain corals are relative safe because they tend to concentrate at flat horizontal surfaces where light conditions are more adequate. However, sun corals spread to horizontal reef substrates as their abundance increases, with contact interactions putting the native coral species at risk. Any efforts to protect $M$. hispida populations would thus aim flat reef habitat, when the density of sun coral colonies is still low and removals feasible. Laboratory rearing of recruits and their transplantation to favorable habitat may also be viewed as a complementary procedure to protect brain corals, since we observed no effects of moving colonies from one place to another, and also no effects of contact with epoxy cement, compared to control colonies in the same area. Therefore, assisted recovery of degraded reefs (Rinkevich 2014, Rodgers et al. 2017) is likely an appropriate restoration 
strategy, especially if transplant individuals are still young brain coral colonies, with growth rates that exceed the ones observed for invasive sun corals.

\section{ACKNOWLEDGEMENTS}

We gratefully acknowledge the CEBIMar technicians Joseilto Medeiros de Oliveira and Eduardo Onuma for their help in field experiments. We also thank Bruna L.P. Luz and Rodrigo Silva for their assistance during the summer field experiment, and Fernando Oliveira for his great work on image edition (Figure 3). This research was funded by the Program "Ciência sem Fronteiras" (CNPq; Conselho Nacional de Desenvolvimento Científico e Tecnológico; Grant \# 400614/2014-6), as a Special Visiting Researcher Fellowship - PVE to CV. We also thank the USP Graduate Program in Comparative Biology for granting a PhD fellowship to ACCB (CNPq \# 159822/2015-7). This is a contribution of the Research Centre for Marine Biodiversity of the University of São Paulo (NP-Biomar/USP).

\section{REFERENCES}

Barrett RDH, Schluter D (2008) Adaptation from standing genetic variation. TREE 23: 38-44

Batista D, Gonçalves JEA, Messano HF, Altvater L, Candella R, Elias LMC, Messano LVR, Apolinário M, Coutinho $R$ (2017) Distribution of the invasive orange cup coral Tubastraea coccinea Lesson, 1829 in an upwelling area in the South Atlantic Ocean fifteen years after its first record. Aq Invas 12 (1): 23-32

Campbell RD (1983) Cnidaria. In Giese, AC e Pearse, JS (eds): Reproduction of marine invertebrates I. Academic Press New York, 133-200

Capel KCC, Toonen RJ, Rachid CTCC, Creed JC, Kitahara MV, Forsman Z, Zilberberg C (2017) Clone wars: asexual reproduction dominates in the invasive range of Tubastraea spp. (Anthozoa: Scleractinia) in the SouthAtlantic Ocean. PeerJ 5: e3873

Castro CB, Pires DO (2001) Brazilian coral reefs: what we already know and what is still missing. Bull Mar Sci 69: 357-371

Ciotti AM, Garcia CAE, Jorge DSF (2010) Temporal and meridional variability of satellite-estimates of surface chlorophyll concentration over the Brazilian continental shelf. Pan Am J Aquat Sci 5: 236-253

Connell JH (1976) Competitive interactions and the species diversity of corals. In: Mackie GO (ed) Coelenterate ecology and behavior. Plenum Press, New York, p 51-58 
Connell JH, Hughes TE, Wallace CC, Tanner JE, Harms KE, Kerr AM (2004) A long-term study of competition and diversity of corals. Ecol Monogr 74: 179-210

Creed JC (2006) Two invasive alien azooxanthellate corals, Tubastraea coccinea and Tubastraea tagusensis, dominate the native zooxanthellate Mussismilia hispida in Brazil. Coral Reefs 25:350

Creed JC, De Paula AF (2007) Substratum preference during recruitment of two invasive recruitment of two invasive alien corals onto shallow-subtidal tropical rocky shores. Mar Ecol Prog Ser 330: 101-111

Creed JC, Fenner D, Sammarco PW, Cairns S, Capel KCC, Junqueira AOR, Cruz I, Miranda RJ, Carlos-Júnior LA, Mantelatto MC, Oigman-Pszczol SS (2016) The invasion of the azooxanthellate coral Tubastraea (Scleractinia: Dendrophylliidae) throughout the world: history, pathways and vectors. Biol Invasions 19 : 283-305

Cruz ICS, Meira VH, Kikuchi RKP, Creed JCC (2016) The role of competition in the phase shift to dominance of the zoanthid Palythoa cf. variabilis on coral reefs. Mar Environ Res 115: 28-35

De Paula AF, Creed JC (2004) Two species of the coral Tubastraea (Cnidaria, Sclerectinia) in Brazil: a case of accidental introduction. Bull Mar Sci 74: 175-183

De Paula, AF, Creed, JC (2005) Spatial distribution and abundance of non-indigenous coral genus Tubastraea (Cnidaria, Scleractinia) around Ilha Grande, Brazil. Braz J Biol 65: 661-673

dos Santos LAH, Ribeiro FV, Creed JC (2013) Antagonism between invasive pest corals Tubastraea spp. and the native reef-builder Mussismilia hispida in the southwest Atlantic. J Exp Mar Biol Ecol 449: 69-76

Fenner D, Banks K (2004) Orange cup coral Tubastraea coccinea invades Florida and the Flower Garden Banks, Northwestern Gulf of Mexico. Coral Reefs 23: 505-507

Ferrari R, Gonzalez-Rivero M, Mumby PJ (2012) Size matters in competition between corals and macroalgae. Mar Ecol Prog Ser 467: 77-88

Ferreira CEL (2003) Non-indigenous corals at marginal sites. Coral Reefs 22: 498

Flores AAV, Christofoletti RA, Peres ALF, Ciotti AM, Navarrete AS (2015) Interactive effects of grazing and environmental stress on macroalgal biomass in subtropical rocky shores: Modulation of bottom-up inputs by wave action. J Exp Mar Biol Ecol 463: 39-48

Fox J, Weisberg S (2011) Multivariate Linear Models in R. An Appendix to An R Companion to Applied Regression, Second Edition.

Ghalambor CK, McKay JK, Carroll SP, Reznick DN (2007) Adaptive versus non-adaptive phenotypic plasticity and the potential for contemporary adaptation in new environments. Funct Ecol 21: 394-407

Glynn PW, Colley SB, Maté JL, Cortés J, Guzman HM, Bailey RL, Feingold JS, Enochs IC (2008) Reproductive ecology of the azooxanthellate coral Tubastraea coccinea in the Equatorial Eastern Pacific: Part V. Dentrophylliidae. Mar Biol 153: 529-544

Global Invasive Species Database - www.invasivespecies.net

Hennessey SM, Sammarco PW (2014) Competition for space in two invasive Indo-Pacific corals - Tubastraea micranthus and Tubastraea coccinea: Laboratory experimentation. J Exp Mar Biol Ecol 459: 144-150

Hoegh-Guldberg O (1999) Climate change, coral bleaching and the future of the world's coral reefs. Mar Freshwater Res 50: 839-66

Hughes TP, Baird AH, Bellwood DR, Card M, Connolly SR, Folke C, Grosberg R, Hoegh-Guldberg O, Jackson JBC, Kleypas J, Lough JM, Marshall P, Nystrom M, Palumbi SR, Pandolfi JM, Rosen B, Roughgarden J (2003) Climate Change, Human Impacts, and the Resilience of Coral Reefs. Science 301: 929-933 
IPCC (2013) Climate Change 2013: The Physical Science Basis. Contribution of Working Group I to the Fifth Assessment Report of the Intergovernmental Panel on Climate Change [Stocker TF, D Qin, G-K Plattner, M Tignor, SK Allen, J Boschung, A Nauels, Y Xia, V Bex and PM Midgley (eds.)]. Cambridge University Press, $1535 \mathrm{pp}$.

Jompa J, McCook LJ (2003) Contrasting effect of turf algae on corals: massive Porites spp. are unaffected by mixed-species turfs, but killed by the red alga Anotrichium tenue. Mar Ecol Prog Ser 158:79-86

Karlson RH (1999) Dynamics of coral communities. Kluwer, Dordebrecht

Lages BG, Fleury BG, Ferreira CEL, Pereira RC (2006) Chemical defense of an exotic coral as invasion strategy. J Exp Mar Biol Ecol 328: 127-135

Lages BG, Fleury BG, Pinto AC, Creed JC (2010) Chemical defenses against generalist fish predators and fouling organisms in two invasive ahermatypic corals in the genus Tubastraea. Mar Ecol 31: 473-482

Lages BG, Fleury BG, Menegola C, Creed JC (2011) Change in tropical rocky shore communities due to an alien coral invasion. Mar Ecol Prog Ser 438: 85-96

Lages BG, Fleury BG, Hovell AMC, Rezende CM, Pinto AC, Creed JC (2012) Proximity to competitors changes secondary metabolites of non-indigenous cup corals, Tubastraea spp., in the southwest Atlantic. Mar Biol 159: 1551-1559

Lang J (1973) Interspecific aggression by scleractinian corals. 2. Why the race is not only to the swift. Bull Mar Sci 23: $260-279$

Lang JC, Chornesky EA (1990) Competition between scleractinian reef corals - a review of mechanisms and effects. In: Dubinsky Z (ed) Ecosystems of the world, vol. 25. Coral reefs. Elsevier, pp 209-252

Lapid Ed, Wielgus J, Chadwick-Furman NE (2004) Sweeper tentacles of the brain coral Platygyra daedalea: induced development and effects on competitors. Mar Ecol Prog Ser 282: 161-171

Lenz M, Da Gama BAP, Gerner NV, Gobin J, Gröner F, Harry A, Jenkins SR, Kraufvelin P, Mummelthei C, Sareyka J, Xavier EA, Wahl M (2011) Non-native marine invertebrates are more tolerant towards environmental stress than taxonomically related native species: Results from a globally replicated study. Environ Res 111: $943-952$

Lopes RM (2009) Informe sobre as espécies exóticas invasoras marinhas no Brasil. Ministério do Meio Ambiente, Curitiba, SC, Brazil

Lubchenco J (1980) Algal zonation in the New England rocky intertidal community - an experimental analysis. Ecology 61: 333-344

Luz BLP, Capel KCC, Zilberberg C, Flores AAV, Migotto AE, Kitahara MV (2018) A polyp from nothing: The extreme regeneration capacity of the Atlantic invasive sun corals Tubastraea coccinea and $T$. tagusensis (Anthozoa, Scleractinia) J Exp Mar Biol Ecol 503: 60-65

Mantelatto MC, Creed JC, Mourão GG, Migotto AE, Lindner A (2011) Range expansion of the invasive corals Tubastraea coccinea and Tubastraea tagusensis in the Southwest Atlantic. Coral Reefs 30: 397

Mantelatto, MC (2012) Distribuição e abundância do coral invasor Tubastraea spp. Msc dissertation, Universidade do Estado do Rio de Janeiro, Rio de Janeiro, RJ, Brazil

McCook L, Jompa J, Diaz-Pulido G (2001) Competition between corals and algae in coral reefs: a review of evidence and mechanisms. Coral Reefs, 19: 400-417

Menge BA (1976) Organization of the New England rocky intertidal community: role of predation, competition, and environmental heterogeneity. Ecol Monogr 46: 355-393 
Migotto AE (1997) Anthozoan bleaching on the southeastern coast of Brazil in the summer of 1994. Proceed 6th Intern Conf Coelenterate Biol, 1995: 329-335

Mizrahi D, Navarrete AS, Flores AAV (2014a) Groups travel further: pelagic metamorphosis and polyp clustering allow higher dispersal potential in sun coral propagules? Coral Reefs 33: 443-448

Mizrahi D, Navarrete AS, Flores AAV (2014b) Uneven abundance of the invasive sun coral over habitat patches of different orientation: An outcome of larval or later benthic processes? J Exp Mar Biol Ecol 452: 22-30

Mizrahi D, Pereira SF, Navarrete AS, Flores AAV (2017) Allelopathic effects on the sun-coral invasion: facilitation, inhibition and patterns of local biodiversity. Mar Biol 164: 139

Nogueira JMM (2003) Fauna living in colonies of Mussismilia hispida (Verril) (Cnidaria: Scleractinia) in four Southeastern Brazilian islands. Braz Arch Biol Tech 46 (3): 421-432

Oigman-Pszczol SS, Figueiredo MAO, Creed JC (2004) Distribution of Benthic Communities on the Tropical Rocky Subtidal of Armação dos Búzios, Southeastern Brazil. Mar Ecol 25 (3): 173-190

PBMC (2012) Painel Brasileiro de Mudanças Climáticas. Volume Especial para a Rio+20. PBMC, Rio de Janeiro, Brazil, 34

Peluso L, Tascheri V, Nunes FLD, Castro CB, Pires DO, Zilberberg C (2018) Contemporary and historical oceanographic processes explain genetic connectivity in a Southwestern Atlantic coral. Sci Rep 8: 2684

Porter JW, Woodley JD, Jason-Smith G, Neigel JE, Battey JF, Dallmeyer DG (1981) Population trends among Jamaican reef corals. Nature 294: 249-250

Price TD, Qvarnström A, Irwin DE (2003) The role of phenotypic plasticity in driving genetic evolution. Proc Soc Lond B. 270: 1433-1440

Rainey PB, Travisano M (1998) Adaptive radiation in a heterogeneous environment. Nature 394: 69-72

Riul P, Targino CH, Júnior LAC, Creed JC, Horta PA, Costa GC (2013) Invasive potential of the coral Tubastraea coccinea in the southwest Atlantic. Mar Ecol Prog Ser 480: 73-81

Rodgers KS, Lorance K, Donà AR, Stender Y, Lager C, Jokiel PL (2017) Effectiveness of coral relocation as a mitigation strategy in Kane'ohe Bay, Hawai'i. PeerJ 5: e3346

Rinkevich B. 2014. Rebuilding coral reefs: does active reef restoration lead to sustainable reefs? Curr Opin Environ Sustain 7:28-36

Sammarco PW, Coll JC, La Barre S, Willis B (1983) Competitive Strategies of Soft Corals (Coelenterata: Octocorallia): Allelopathic Effects on Selected Scleractinian Corals. Coral Reefs 1: 173-178

Sampaio CLS, Miranda RJ, Maia-Nogueira R, de Anchieta CC, Nunes J (2012) New occurrences of the nonindigenous orange cup corals Tubastraea coccinea and T. tagusensis (Scleractinia: Dendrophylliidae) in Southwestern Atlantic. Check List 8: 528-530

Schneider CA, Rasband WS, Eliceiri KW. 2012. NIH Image to ImageJ: 25 years of image analysis. Nat Methods 9:671-675

Sea temperature Organization - www.seatemperature.org

Silva R, Vinagre C, Kitahara MV, Acorsi I, Mizrahi D, Flores AAV (2019) Sun coral invasion of shallow rocky reefs: effects on mobile invertebrate assemblages in Southeastern Brazil. Biol Invasions 21 (4): 13391350

Sinnott JA, Cai T (2016) Inference for survival prediction under the regularized Cox model. Biostat 17 (4): 692707 
Soares MO, Davis M, Carneiro PBM (2018). Northward range expansion of the invasive coral (Tubastraea tagusensis) in the southwestern Atlantic. Mar Biodiv, 48: 1651-1654

Tanner JE (1997) Interspecific competition reduces fitness in scleractinian corals. J Exp Mar Biol Ecol 214: 1934

Taylor P, Kaplan EL, Meier P (1958) Nonparametric estimation from incomplete observations. J Am Stat Assoc 53: 457-481

Underwood AJ (1996) Experiments in ecology: their logical design and interpretation using analysis of variance. Cambridge University Press.

Valentim SS, Bernardes MEC, Dottori M, Cortezi M (2013) Low-frequency physical variations in the coastal zone of Ubatuba, northern coast of São Paulo State, Brazil. Braz Jour Ocean 61(3):187-193

Vermeij, MJA (2006) Early life-history dynamics of Caribbean coral species on artificial substratum: the importance of competition, growth and variation in life-history strategy. Coral Reefs 25: 59-71

Winter APM, Chaloub RM, Duarte GAS, Castro CB (2016) Photosynthetic responses of corals Mussismilia harttii (Verrill, 1867) from turbid waters to changes in temperature and presence/absence of light. Braz J Ocean 64 (3): 203-216

Zilberberg C, Peluso L, Marques JA, Cunha H (2014) Polymorphic Microsatellite Loci for Endemic Mussismilia Corals (Anthozoa: Scleractinia) of the Southwest Atlantic Ocean. J Heredity, 105 (4): 572-575 
Chapter 2: 'Invasive sun corals and warming pose independent threats to the brain coral Mussismilia hispida in the Southwestern Atlantic' was submitted for publication in the Journal Marine Ecology Progress Series.

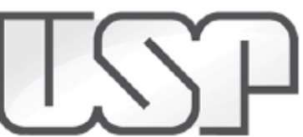

Andreia Cristina Barbosa de Oliveira <deiabarbosa@usp.br>

\section{Marine Ecology Progress Series Submission Received}

1 message

meps-ed@int-res.com <meps-ed@int-res.com>

To: deiabarbosa@usp.br

\section{Dear Andreia Barbosa}

This is to inform you that Prof. Augusto Flores has submitted the manuscript entitled "Invasive sun corals and warming pose independent threats to the brain coral Mussismilia hispida in the Southwestern Atlantic" to "Marine Ecology Progress Series". You are listed as one of the authors of this manuscript.

Further correspondence on this submission will be conducted directly between Prof. Augusto Flores and the editorial office.

With kind regards,

The Editorial Office 


\section{Chapter 3: TEMPERATURE-DRIVEN SECONDARY COMPETENCE WINDOWS MAY INCREASE THE DISPERSAL POTENTIAL OF INVASIVE SUN CORALS}

Barbosa, A. C. C.; Vinagre, C.; Mizrahi, D.; Flores, A. A. V.

Abstract - Invasive sun corals exhibit outstanding development plasticity during early ontogenesis, which may greatly affect the pelagic duration of propagules and hence their dispersal potential. Remarkably, a small proportion of larvae may not directly settle on the benthic habitat, but metamorphose to planktonic polyps. We show the latter may settle successfully, eventually opening a secondary competence window (SCW). Based on local conditions (Southeast Brazil), delayed SCWs were confirmed at average summer $\left(26^{\circ} \mathrm{C}\right)$ and, especially, at heatwave $\left(30^{\circ} \mathrm{C}\right)$ temperature, allowing an escape response from habitats where larval mortality rates are high and mass-mortality events of colonies, later on, more likely. Despite a higher frequency of pelagic metamorphosis, no SCWs were observed at average winter $\left(22^{\circ} \mathrm{C}\right)$ and cold-front $\left(19^{\circ} \mathrm{C}\right)$ conditions. Climate change may thus favor large-scale dispersal of competent pelagic polyps and further promote range extensions to subtropical and warm-temperate regions where temperature conditions (ca. $22^{\circ} \mathrm{C}$ ) for propagule survival and settlement success are best.

Keywords: Tubastraea; biological invasions; global warming; rocky reefs; Southwestern Atlantic 


\section{INTRODUCTION}

The environmental control of the dispersal potential of pelagic propagules plays a key role on the ecology of benthic marine invertebrates, since it may largely determine the dynamics of spatially-structured populations and communities at several different scales (e.g. Kinlan and Gaines 2003, Cowen et al. 2006). In this context, temperature is considered a major environmental driver, predictably affecting the physiology of marine larvae (O'Connor et al. 2007). In general, higher temperatures tend to increase metabolic rate and shorten the pelagic larval duration, at the cost of increased mortality (e.g. Drent 2002, Bassim and Sammarco 2003, Randall and Szmant 2009). Because the time larvae spend in the plankton may translate to dispersal potential, sea-surface warming in a global scenario of climate change may, other things being equal, greatly decrease overall dispersal potential and hence connectivity among benthic populations ( $\mathrm{O}^{\prime}$ Connor et al. 2007; Munday et al. 2009). However, the development pathways through early planktonic stages may greatly change under adverse environmental conditions, including temperature anomalies, ultimately affecting pelagic periods and transport distances. Still, besides dormancy in specific stages of a few invertebrate groups, such as copepods (Dahms 1995), hydrozoans (Piraino et al. 2004), and barnacles (Pineda et al. 2005), such effects are seldom reported.

Sun corals Tubastraea spp (T. tagusensis and T. coccinea combined) are alien and invasive species along tropical and subtropical coastlines in the Southwestern Atlantic Ocean (Fenner and Banks 2004; dos Santos et al. 2013). Native to the Indo-Pacific, sun corals were first reported at Bacia de Campos, RJ, Southeast Brazil in the late 80 's and have since then expanded to numerous sites along the Brazilian coast (over 3,850 km; Creed et al. 2016, Soares et al. 2018), profoundly changing the structure of local benthic 
communities (dos Santos et al. 2013, Mizrahi et al. 2017, Silva et al. 2019). The invasion history along the region suggests a very high dispersal potential of invasive sun corals. There is compelling evidence indicating transport through oil platforms and tanker ships (de Paula and Creed 2004), but previous work indicates that development plasticity during larval and early-postlarval ontogenesis may also play a role. Sun coral lecithotrophic planulae typically settle in a few days after release, but a small fraction of larvae may metamorphose to feeding pelagic polyps that may endure in the plankton for longer and thus travel larger distances in the ocean (Mizrahi et al. 2014).

Here, we first document pelagic metamorphosis to the polyp stage followed by successful settlement, and consider this an alternative development pathway to the most commonly typified for corals, in which larval metamorphosis occurs only after attachment to appropriate habitat. The competence window for settlement was shown to be remarkably variable in scleractinian coral species, even within a single larval cohort (Connolly and Baird 2010), but here we hypothesized that such an alternative ontogenetic pathway, involving also pelagic metamorphosis, may actually underlie a discrete and secondary competence window (SCW). This dimorphic character of planktonic propagules determines the potential for dispersal and colonization of both short and long-distance reef habitats. This secondary competence window is put to a test under contrasting thermal regimes, compatible to both present-day summer and winter temperature conditions, as well as far ranging extremes (warm and cold), that will likely be more frequent and endure for longer periods by 2100 (PBMC 2012, IPCC 2013). We predicted a secondary, more delayed, competence window to occur at temperature regimes in which overall larval or adult performance is poorer, thus allowing enhanced dispersal and increased chances for settlement in a more favorable temperature regime. Critical dispersal distances may be in 
the order of just a few tens of km, or even smaller, compatible to the size of frontal eddies (Park and Chung 1999) and to the variation of the thermocline depth (Riegl and Piller 2003), which may impose consistent spatial structure of thermal regimes across shallow reef habitats.

\section{MATERIALS AND METHODS}

Several small colonies of the yellow cup coral Tubastraea tagusensis Wells, 1982 (ca. $6 \mathrm{~cm}$ diameter) were collected in November of 2017 at Búzios Island (2347'54.2" S $\left.45^{\circ} 09^{\prime} 24.6^{\prime \prime} \mathrm{W}\right)$, located $25 \mathrm{~km}$ off the coast of São Paulo state, Brazil, and brought to the Center for Marine Biology, University of São Paulo (CEBIMar - USP). Colonies were acclimated for $30 \mathrm{~d}$ in a $500 \mathrm{~L}$ tank, supplied with running seawater, and fed every other day with living plankton. During a major larval release event, from December 10 to 15, all planulae were scooped out of the acclimating tank and random sets of 50 active pyriform larvae were placed in $250 \mathrm{ml}$ glass containers, filled with filtered seawater ( $20 \mu \mathrm{m}$ mesh), and containing small granite cobble stones, collected at Baleeiro Head within the CEBIMar area, which provided natural settlement surfaces. During 35 days, replicate containers $(n=$ 10), kept in incubating chambers at natural photoperiod (13L : 11D), were randomly assigned to one of the following temperature treatments: $22^{\circ} \mathrm{Cl}$ and $26^{\circ} \mathrm{C}(\mathrm{H})$, representing current winter and summer conditions, and $19^{\circ} \mathrm{C}(\mathrm{C}-)$ and $30^{\circ} \mathrm{C}(\mathrm{H}+)$, representing presentday temperature extremes that can be observed during the passage of winter cold fronts and summer heatwaves, respectively, but that will probably become much more frequent by 2100 , in a climate change scenario (PBMC 2012, IPCC 2013). Every other day, the number of swimming planulae, planktonic polyps, and settlers was recorded, and nearly $90 \%$ of the water was renewed for each container using pipettes to prevent any turbulence that could 
stress larvae or polyps. In order to avoid potential artifact effects of rearing conditions, the temperature settings of chambers and the position of replicate containers within chambers changed on several different dates during the experiment.

One-way analyses of variance were used to compare (i) overall mortality, (ii) the number of living planktonic polyps, (iii) and cumulative settlement by the end of the experiment, as well as respective rates [average time for (iv) death, (vi) planktonic metamorphosis, and (vi) settlement, in days], among temperature treatments. When needed, data were log-transformed in an attempt to meet homoscedasticity. The general procedure was however maintained in the cases where transformation did not solve the issue because sample size was large and the dataset balanced [ $=10$; except for the time for settlement ( $n=9)$ and metamorphosis to planktonic polyps $(n=6)$ owing to 'zero' trials], making the general procedure robust to heteroscedasticity (Underwood 1997). Despite it being a markedly conservative method (Sokal and Rohlf 2012), we used the sum of squares simultaneous procedure (SS-STP) for a posteriori analyses because it is not restricted to pairwise comparisons, permitting all possible contrasts between groups of means. This was important here because the variables measured in this study did not appear to respond to any temperature gradients, but rather to threshold values that could not be predicted beforehand.

We also observed that a small fraction of planktonic polyps was capable to settle. Because this alternative path could deeply affect local population dynamics and dispersal potential, we first compared the proportion of living planktonic polyps that successfully settled among temperature treatments using a chi-square $2 \times 4$ test of independence [planktonic polyp condition (polyps that remained pelagic; polyps that settled) vs. temperature ( $\mathrm{C}-; \mathrm{C} ; \mathrm{H} ; \mathrm{H}+)$ ]. Then, we carried out separate randomization procedures for 
each temperature treatment to test whether this unusual alternative strategy underlies a secondary competence window. For that, the source population of temperature-specific larval settlement times, considered here a standard, was sampled without replacement 1,000 times, setting $n$ as the number of planktonic polyps that settled on cobble stones in that specific temperature treatment. The resulting sampled means were distributed in 0.7 d size classes, and the null hypothesis supporting a single competence window for larvae and planktonic polyps was rejected if the observed average time for polyp settlement fell in one of the two distribution tails merging the $2.5 \%$ more extreme values (a two-tailed test at $\alpha=0.05)$. The number of observations of larval and polyp settlement times varied from 191 to 322 , and from 4 to 10 , respectively, among temperature treatments.

\section{RESULTS AND DISCUSSION}

Currently, climate change and the rising of ocean temperature represent a major threat to coral reefs worldwide (Donner 2009). Bleaching is possibly the most conspicuous impact caused on mature colonies, but effects on early planktonic life stages, which are relatively overlooked, can actually be more harmful to corals (Keshavmurthy et al. 2014). Although survival and growth rates of adult sun coral colonies are apparently unaltered by present-day seasonal temperature variations in Southeastern Brazil (Barbosa et al. 2019, submitted), the results of this study show clear temperature effects on the performance of pelagic stages of the sun coral Tubastraea tagusensis, with threshold values not only at extreme temperature settings (mortality and overall settlement), but also at average seasonal conditions (living pelagic polyps). Overall mortality $\left(F_{3,36}=2.91 ; p=0.047\right)$ at cold (C-) and warm $(\mathrm{H}+)$ extreme temperatures more than doubled the estimate observed at current winter conditions ( $\mathrm{C} ; p<0.05$; Fig. $1 \mathrm{~A}$ ). Although it approximated to the values 
observed at extreme settings, nothing can be really concluded on present-summer average temperature $(\mathrm{H})$ owing to the slightly larger variance observed in this treatment. Mortality rates also differed among treatments $\left(F_{3,36}=4.23 ; p=0.012\right)$, with sun coral larvae undergoing nearly $30 \%$ faster mortality at warm $(\mathrm{H}, \mathrm{H}+$ ) compared to low (C, $\mathrm{C}-$ ) temperatures ( $p<0.05 ;$ Fig $1 \mathrm{~A}$ ), probably owing to increased metabolic rates (as in Bassim and Sammarco 2003) in the former group. Combined, these results indicate that propagules released in an $\mathrm{H}+$ environment will not have, on average, much time (ca. $13 \mathrm{~d}$ ) to escape adverse conditions and find a more amenable reef habitat. Effects on overall settlement were also significant $\left(F_{3,36}=4.58 ; p=0.008\right)$, showing that $C$ - conditions, compatible to present winter cold fronts, reduces the numbers of settlers by $40 \%$ compared to a common standard (ca. 32-33 settlers per container) for the other three treatments $(p<0.05 ;$ Fig. $1 \mathrm{~B})$. Average time for settlement $\left(F_{3,32}=3.00 ; p=0.045\right)$ was lower (i.e. settlement rate higher) for individuals maintained at the highest temperature $(\mathrm{H}+)$, contrasting with those held at intermediate temperatures $(\mathrm{H}, \mathrm{C} ; p=0.052$; Fig. 1B), probably due to increased larval metabolic rates and faster depletion of lipid reserves (O'Connor et al. 2007), along with an increment of swimming activity enhancing larval contact with settlement surfaces. Time to settle was more variable for the $\mathrm{H}$ - treatment preventing any conclusions for this group.

Considering more localized population dynamics, mortality and settlement combined suggest superior performance of sun-coral larvae at $22^{\circ} \mathrm{C}(\mathrm{C})$, as long as planulae held at this temperature survived the most (Fig. 1A), and clustered together with treatments $\mathrm{H}$ and $\mathrm{H}+$ within the group exhibiting higher overall settlement (Fig. 1B). In other words, the supply-side ecology of sun corals seems most favorable at subtropical / warm temperate climate regimes, which are found at the southernmost limit of the current 
invasive range along the SW Atlantic (i.e. Arvoredo Archipelago, SC, Brazil). However, interpretations are more challenging if larger-scale dispersal is taken into account. This is because a small but non-negligible fraction of larvae undergo pelagic metamorphosis (Fig. 1C), a rare development pathway in corals (Richmond, 1985), leading to feeding planktonic polyps that may remain longer in the plankton and therefore travel larger distances (Mizrahi 2014). The number of pelagic polyps produced in each treatment, as well as those remaining alive at the end of trials $\left(F_{3,36}=2.75 ; p=0.021\right)$, was higher at cooler $(\mathrm{C}, \mathrm{C}$-; around 6-8 individuals per container) compared to warmer temperatures $(\mathrm{H}, \mathrm{H}+$; ca. 2 individuals per container; Fig. 1C), with no differences on the average time for pelagic metamorphosis among treatments, or treatment groups ( $p>0.05$; Fig. $1 \mathrm{C})$, in spite of a marginally significant omnibus test $\left(F_{3,20}=3.08 ; p=0.051\right)$. Differently from the frequency of larvae that metamorphosed into polyps in the water column, the percentage of planktonic polyps that actually settled on rocks (10\%) did not vary significantly across treatments $\left(\chi^{2}=4.27 ; p>0.05\right)$.

The higher frequency of pelagic polyps (Fig. 1C), together with the decreased metabolic rates expected at lower temperatures (as reviewed by O'Connor 2007), would suggest a higher dispersal potential for offspring released at $\mathrm{C}$ - and $\mathrm{C}$, compared to $\mathrm{H}$ and $\mathrm{H}+$ conditions. Surprisingly, however, the experimental evidence does not support a secondary competence window for the cooler temperature regimes, but for the warmer ones instead (Fig. 2). At C- and C (19 and $22^{\circ} \mathrm{C}$; Fig. 2A-B), the average time for settlement of planktonic polyps falls in the non-rejection zone $(p>0.05)$ of frequency distributions drawn from random samples of larval settlement, suggesting that swimming polyps and planulae are functionally the same in this cool water temperature range. In contrast, the average time for settlement of planktonic polyps released at $\mathrm{H}$ and $\mathrm{H}+\left(26\right.$ and $30^{\circ} \mathrm{C}$; Fig. 
2C-D) falls well beyond the critical cut-off value at the right side of distributions generated from observations of larval settlement at their respective treatments $(p<0.05)$, that is, the hypothesis of a secondary competence window is sustained at the warm water range. After $35 \mathrm{~d}$, pelagic polyps became less active and remained most of the time close to the bottom of containers without settling, probably because of incipient production of carbonate exoskeletons. We regard such polyps as non-competent stages (i.e. 'senescent', as in Hadfield et al. 2001). Any attempts to identify a unifying mechanism explaining the higher production of planktonic polyps at C- and C, but a secondary competence window restricted $\mathrm{H}$ and $\mathrm{H}+$, remains premature. Still, results were partially consistent with predictions. We hypothesized secondary dispersal under unfavorable temperature regimes for propagule performance; this is sustained for the $\mathrm{H}+$ treatment, in which mortality was high and a secondary settlement window was verified, but not for the C- treatment, in which overall settlement was low but no evidence of a secondary competence window was observed. We also found support for enhanced dispersal under risky conditions to adults. Prolonged periods at $26^{\circ} \mathrm{C}$, and certainly at $30^{\circ} \mathrm{C}$, would signal risky habitat conditions, where thermal stress may directly or indirectly (e.g. through follow-up disease outbreaks; Garrabou et al. 2001, Bruno et al. 2007) cause large mortality events. In this sense, extending the pelagic propagule duration from 6 to $20 \mathrm{~d}$ would enable additional transport within a range of a few tens of km (Shanks et al. 2003), over which topography, reef steepness and the frequency and intensity of upwelling may vary considerably, eventually setting the conditions for thermal refugia (Riegl and Piller 2003). Considering the invasive biology of sun corals in the SW Atlantic, we thus predict maximum propagule dispersal potential from invaded sites at lower latitudes, and especially during warming events, 
which will become more intense and frequent over the next decades (PBMC 2012, IPCC 2013).

The case we present here is comparable to the dimorphic dispersal potential found among sibling offspring of the polychaete Hydroides dianthus (Toonen and Pawlik 2001) and the gastropod Alderia modesta (Krug 2001). In all three cases, the more dispersive morphotype is less abundant, and likely a 'bet' for large-scale dispersal, away from the natal site. While there might be strong genetic determination of morph proportions (Toonen and Pawlik 2001), unsuitable local conditions signaling poor benthic habitat may greatly increase the proportion of dispersers (Krug 2001, this study). A better understanding of the interplay between genetic and environmental factors controlling the dispersal potential of pelagic propagules is thus crucial to unravel distribution range shifts of marine species, including invasive ones, in a climate change scenario. 

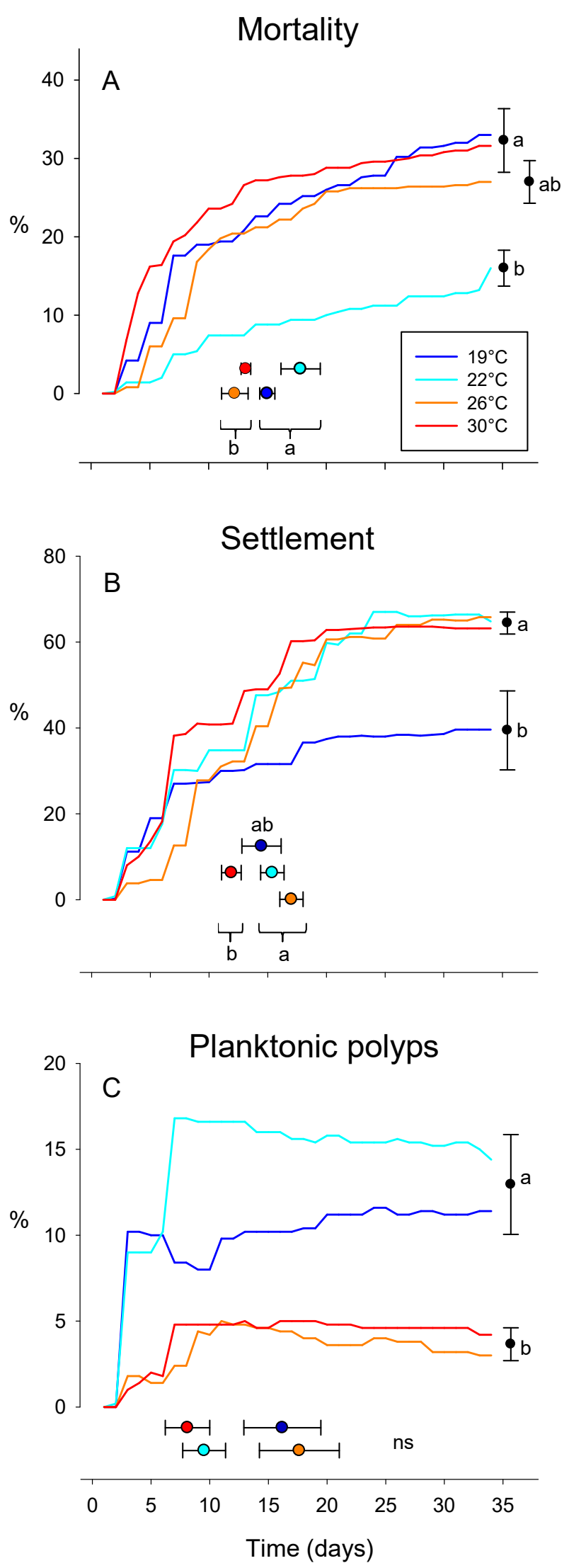

Figure 1. Temporal trends (lines) and rates (events per day, as scatter in matching colors) of larval performance variables at the different temperature treatments: (A) mortality curves and average time to death, (B) cumulative and average time to overall settlement, and (C) fluctuation of the number of planktonic polyps (declines accounting for settlement and mortality) and average time to pelagic metamorphosis. Lines are average values calculated for replicate containers within each temperature treatment $(n=10)$. Statistical comparisons were carried out to compare the total of deaths and numbers of settlers in $(A)$ and $(B)$, and the number of living polyps at the end of the experiment $(C)$, as well as respective rates $(A, B, C)$, among temperature treatments. Post-hoc procedures were not restricted to pairwise comparisons between single treatments, but to all possible partitions of treatment means, using the sum of squares simultaneous test procedure (see methods). Group averages sharing one same low case letter are not statistically different $(p>$ $0.05)$. In all cases, error bars represent \pm 1 SE. 

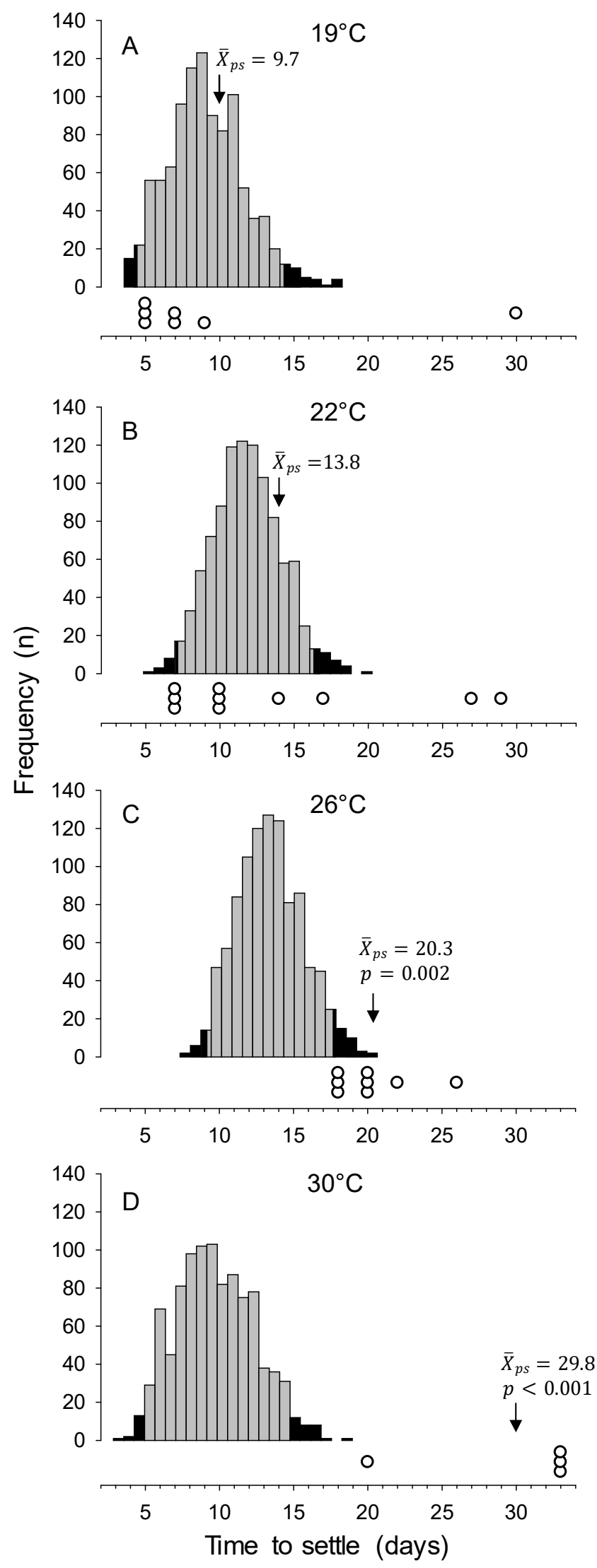

Figure 2. Results of randomization procedures testing the hypothesis of a secondary competence window for the few planktonic polyps (c.a. $10 \%$, see main text) that settled during trials (as white dots below histograms). One thousand random samples of standard settlement time (i.e. larval settlement) were used to calculate frequency distributions for each temperature treatment. Rejection zones (5\%) are shown in black. Arrows indicate the average time for polyp settlement (ps). 


\section{ACKNOWLEDGEMENTS}

We gratefully acknowledge the CEBIMar technicians Joseilto Medeiros de Oliveira and Eduardo Onuma for their assistance in the collection of coral colonies. This research was funded by the Program "Ciência sem Fronteiras" (CNPq; Conselho Nacional de Desenvolvimento Científico e Tecnológico; Grant \# 400614/2014-6), as a Special Visiting Researcher Fellowship - PVE to CV. CV also acknowledges a researcher position and the project UID/MARE/04292/2019, funded by Fundação para a Ciência e a Tecnologia (Portugal). We also thank the USP Graduate Program in Comparative Biology for granting a PhD fellowship to ACCB (CNPq \# 159822/2015-7). This is a contribution of the Research Centre for Marine Biodiversity of the University of São Paulo (NP-Biomar/USP).

\section{REFERENCES}

Barbosa ACC, Vinagre C, Mizrahi D, Duarte RC, Flores AAC (submitted) Invasive sun corals and warming pose independent threats to the brain coral Mussismilia hispida in the Southwestern Atlantic. Mar Ecol Prog Ser

Bassim KM, Sammarco PW (2003) Effects of temperature and ammonium on larval development and survivorship in a scleractinian coral (Diploria strigose). Mar Biol 142: 241-252

Bruno JF, Selig ER, Casey KS, Page CA, Willis BL, Harvell CD, Sweatman H, Melendy AM (2007) Thermal stress and coral cover as drivers of coral disease outbreaks. PLoS Biol 5: 1220-1227

Connolly SR, Baird AH (2010) Estimating dispersal potential for marine larvae: dynamic models applied to scleractinian corals. Ecology 91 (12): 3572-3583

Cowen RK, Paris CB, Srinivasan A (2006) Scaling of connectivity in marine populations. Science 311: 522-527

Creed JC, Fenner D, Sammarco PW, Cairns S, Capel KCC, Junqueira AOR, Cruz I, Miranda RJ, Carlos-Júnior LA, Mantelatto MC, Oigman-Pszczol SS (2016) The invasion of the azooxanthellate coral Tubastraea (Scleractinia: Dendrophylliidae) throughout the world: history, pathways and vectors. Biol Invasions 19: 283-305

Dahms (1995) Dormancy in the Copepoda - an overview. Hydrobiologia 306: 199-211

de Paula AF, Creed JC (2004) Two species of the coral Tubastraea (cnidaria, Scleractinia) in Brazil: a case of accidental introduction. Bull Mar Sci 74: 175-183

dos Santos LAH, Ribeiro FV, Creed JC (2013) Antagonism between invasive pest corals Tubastraea spp. and the native reef-builder Mussismilia hispida in the southwest Atlantic. J Exp Mar Biol Ecol 449: 69-76 
Donner SD (2009) Coping with commitment: Projected thermal stress on coral reefs under different future scenarios. PLoS ONE 4 (6): e5712

Drent J (2002) Temperature responses in larvae of Macoma balthica from a northerly and southerly population of the European distribution range. J Exp Mar Biol Ecol 275: 117-129

Fenner D, Banks K (2004) Orange cup coral Tubastraea coccinea invades Florida and the Flower Garden Banks, Northwestern Gulf of Mexico. Coral Reefs 23: 505-507

Garrabou J, Perez T, Sartoretto S, Harmelin JG (2001) Mass mortality event in red coral Corallium rubrum populations in the Provence region (France, NW Mediterranean). Mar Ecol Prog Ser 217: 263-272

IPCC (2013) Climate Change 2013: The Physical Science Basis. Contribution of Working Group I to the Fifth Assessment Report of the Intergovernmental Panel on Climate Change [Stocker TF, D Qin, G-K Plattner, M Tignor, SK Allen, J Boschung, A Nauels, Y Xia, V Bex and PM Midgley (eds.)]. Cambridge University Press, 1535 pp.

Keshavmurthy S, Fontana S, Mezaki T, Gonzalez LdC, Chen CA (2014) Doors are closing on early development in corals facing climate change. Sci Reports 4: 5633

Kinlan BP, Gaines SD (2003) Propagule dispersal in marine and terrestrial environments: A community perspective. Ecology 84: 2007-2020

Krug PJ (2001) Bet-hedging dispersal strategy of a specialist marine herbivore: a settlement dimorphism among sibling larvae of Alderia modesta. Mar Ecol Prog Ser 213: 177-192

Mizrahi D, Navarrete SA, Flores AAV (2014) Groups travel further: pelagic metamorphosis and polyp clustering allow higher dispersal potential in sun coral propagules. Coral Reefs 33: 443-448

Mizrahi D, Pereira SF, Navarrete AS, Flores AAV (2017) Allelopathic effects on the sun-coral invasion: facilitation, inhibition and patterns of local biodiversity. Mar Biol 164: 139

Munday PL, Leis JM, Lough JM, Paris CB, Kingsford MJ, Berumen ML, Lambrechts J (2009) Climate change and coral reef connectivity. Coral Reefs 28: 379-395

O'Connor MI, Bruno JF, Gaines SD, Halpern BS, Lester SE, Kinlan BP, Weiss JM (2007) Temperature control of larval dispersal and the implications for marine ecology, evolution and conservation. PNAS 104 (4): 12661271

Park K-A, Chung JY (1999) Spatial and temporal scale variations of sea surface temperature in the East Sea using NOAA/AVHRR data. J Oceanogr 55: 171-288

PBMC (2012) Sumário Executivo do Volume 1 - Base Científica das Mudanças Climáticas. Contribuição do Grupo de Trabalho 1 para o 1o Relatório de Avaliação Nacional do Painel Brasileiro de Mudanças Climáticas. Volume Especial para a Rio+20. PBMC, Rio de Janeiro, Brasil, 34 pp.

Pineda J, DiBacco C, Starczak V (2005) Barnacle larvae in ice: Survival, reproduction, and time to postsettlement metamorphosis. Limnol Oceanogr 50: 1520-1528

Piraino S, De Vito D, Schmich J, Bouillon J, Boero F (2004) Reverse development in Cnidaria. Can J Zool 82: 1748-1754

Randall CJ, Szmant AM (2009) Elevated temperature reduces survivorship and settlement of the Caribbean scleractinian coral, Favia fragum (Esper). Coral Reefs 28: 537-545

Richmond RH (1985) Reversible metamorphosis in coral planula larvae. Mar Ecol Prog Ser 22: 181-185

Riegl B, Piller WE (2003) Possible refugia for reefs in time of environmental stress. Int J Earth Sci 92: 520-531 
Silva R, Vinagre C, Kitahara MV, Acorsi I, Mizrahi D, Flores AAV (2019) Sun coral invasion of shallow rocky reefs: effects on mobile invertebrate assemblages in Southeastern Brazil. Biol Invasions 21 (4): 13391350

Shanks AL, Grantham BA, Carr MH (2003) Propagule dispersal distance and the size and spacing of marine reserves. Ecol Appl 13 (1): S159-S169

Soares MO, Davis M, Carneiro PBM (2018) Northward range expansion of the invasive coral (Tubastraea tagusensis) in the southwestern Atlantic. Mar Biodiv 48: 1651-1654

Sokal RR, Rohlf FJ (2012) Biometry, 4th Ed. W.H. Freeman and Company.

Toonen RJ, Pawlik JR (2001) Foundations of gregariousness: a dispersal polymorphism among the plankton larvae of a marine invertebrate. Evolution 55 (12): 2439-2454

Underwood AJ (1997) Experiments in ecology: their logical design and interpretation using analysis of variance. Cambridge University Press. 
Chapter 3: 'Temperature-driven secondary competence windows may increase the dispersal potential of invasive sun corals' was submitted for publication in the Journal Marine Biology.

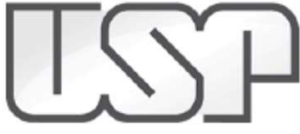

Andreia Cristina Barbosa de Oliveira <deiabarbosa@usp.br>

\section{MABI-D-19-00276 - Submission Confirmation}

1 message

Marine Biology (MABI) <em@editorialmanager.com>

Wed, Jun 12, 2019 at 5:11 PM

Reply-To: "Marine Biology (MABI)" <valli.paramasivan@springernature.com>

To: Andreia Cristina Barbosa <deiabarbosa@usp.br>

Dear Mrs. Barbosa,

Thank you for submitting your manuscript, Temperature-driven secondary competence windows may increase the dispersal potential of invasive sun corals, to Marine Biology.

The submission id is: MABI-D-19-00276

Please refer to this number in any future correspondence.

During the review process, you can keep track of the status of your manuscript by accessing the journal's website

Should you require any further assistance please feel free to e-mail the Editorial Office by clicking on "Contact Us" in the menu bar at the top of the screen.

With kind regards

Springer Journals Editorial Office

Marine Biology 


\section{GENERAL CONCLUSIONS}

The invasion of sun corals in the southwest Atlantic can be considered one of the most outstanding in the history of marine biological invasions. These corals have spanned their range over Brazilian coastal reefs in more than 3,500 km in not much more than 30 years (Creed et al. 2016, Soares et al. 2018). Their remarkable capacity of rapidly forming high-density patches at recently invaded areas is a result of several features qualifying these corals as successful invaders. They present high juvenile growth rates, which can be considered surprising, since they do not contain symbiotic algae that could contribute to their energetic budget through photosynthesis (Vermeij 2006). Their early maturation allows small-sized colonies, with only two polyps, to produce propagules, frequently through asexual reproduction (Glynn et al. 2008). Released planulae tend to settle close to parental colonies, performing gregarious (de Paula \& Creed 2007) and fast self-recruitment (de Paula et al. 2014), at minimal propagule loss (the less time larvae spend in the water, the less they are exposed to predator-pressure; Underwood \& Fairweather 1989, Hughes et al. 2000). Though colonies can be physically removed by nesting pomacentrid fishes (Mizrahi et al. 2016), they also have the ability to form new polyps from remaining small fragments (Luz et al. 2018). All these features, together with the lack of predators (Lages et al. 2010, Moreira \& Creed 2012) or superior competitors (Hennessey \& Sammarco 2014, Sammarco et al. 2015) have enabled sun corals to monopolize long stretches of rocky habitats, changing the structure of Brazilian benthic communities (Lages et al. 2011, Silva et al. 2019).

There is no record, to our knowledge, of sun corals dominating reef habitats in their native range as they do in invaded areas, probably because in their native ecoregion their abundance is regulated by natural enemies. Hence, the invasion of sun corals along the 
Southwestern Atlantic invasion is perfectly compatible to the 'enemy release hypothesis' (Keane \& Crawley 2002). This hypothesis explains successful invasion in plants, and states that when introduced in an exotic region, a species experiences a decrease in regulation by herbivores (i.e. predators) and other natural enemies (i.e. competitors), resulting in a rapid increase of its distribution and abundance (Keane \& Crawley 2002). Despite being commonly applied to a completely different environment, the 'enemy release hypothesis' appears to be plausible and parsimonious to explain the rapid range extension and the overall dominance of sun corals in Brazilian coastal reefs.

As congeners Tubastraea tagusensis and $T$. coccinea have many features in common and were supposed to have niche similarities that would be reflected in smallscale aggregation (Shinen \& Navarrete 2010, 2014). On the other hand, they are great interspecific competitors (e.g. Creed 2006, dos Santos et al. 2013, Hennessey \& Sammarco 2014, Sammarco et al. 2015) and having space as a limiting factor (Lages et al. 2010), they would present local-scale negative associations as a result of spatial segregation. Surprisingly, it is shown in Chapter 1 that at a local small-scale, invasive sun corals appear to be neutrally coexistent (as defined by Chesson 2010). In other words, the presence or the absence of one species does not favor or harm the other and their occurrences can be modelled as completely independent events. At larger scales (tens of km), overall species proportions were uneven at locations with high sun coral coverage, consistent to founder effects (Vieira et al. 2018a, b), which might be secondarily regulated by local propagule pressure and environmental filtering. Stochastic processes, such as temperature fluctuations or water turbulence might regulate corals depth occurrence (Sheppard 1982), where species more tolerant to high temperature are more abundant at shallow depths, close to the surf-zone (Kahng et al. 2012). Sun corals vertical distribution suggest possible 
temperature preferences coherent with the temperature range at both native areas, warmer to T. coccinea $\left(26.7-29^{\circ} \mathrm{C}\right)$ than to T. tagusensis $\left(21.4-25.8^{\circ} \mathrm{C}\right)$. Therefore, the difference on sun corals coverage proportions across locations is probably controlled by large scale stochastic processes, then shaped by strong founder effects and propagule pressure.

The current distribution of sun corals is directly explained by transport of oil and gas platforms or the traffic of marine vessels (e.g. De Paula \& Creed 2005, Da Silva et al. 2014, Creed et al. 2016). The dispersal potential of larvae has been overlooked because of their usual short pelagic duration (3-7 days), short competence window (up to only 18 days; de Paula et al. 2014) and gregarious settlement behavior (Creed \& De Paula 2007). Results in Chapter 2 corroborate that most sun coral larvae do settle rapidly, suggesting high potential for self-recruitment, but they also confirm that a small fraction of larvae undergoes pelagic metamorphosis, turning into planktonic polyps with increased dispersal potential (as in Mizrahi et al. 2014). A novel finding here is that propagule dimorphism may allow enhanced dispersal potential through a temperature-regulated secondary competence window for planktonic polyps, increasing pelagic larval duration and therefore additional transport to unoccupied habitats. For invading sun corals, increased larval dispersal of a few individuals can be viewed as a bet-hedging strategy allowing species range expansions.

Besides stochastic processes, biological interactions are major regulators of benthic community structure (Menge 1976, Lubchenco 1980), where interspecific competition plays a key-role in the assemblage composition (Menge \& Sutherland 1976, Carothers \& Jaksić 1984). It is evident that sun corals are superior competitors towards native species in the invaded Southwest Atlantic region (e.g. Creed 2006, dos Santos et al. 2013, Luz \& 
Kitahara 2017). Most sun coral species are originally distributed in the Indo-Pacific Ocean, which is the center of global marine diversity for several major taxa including fish, crustaceans and corals (Roberts et al. 2002), with nothing less than $75 \%$ of the coral reefs worldwide (Bruno \& Selig 2007). Brazilian coral reefs are significantly less diverse, including only fifteen scleractinian species (Castro \& Pires 2001), an evolutionary scenario that could supposedly have led endemic species to a diminished aggressiveness compared to species of coral reef communities from other locations (Grillo et al. 2017). Thus, the more competitive environment in the Indo-Pacific has probably forced the selection of traits providing invasive sun-corals a competition advantage over scleractinians of the Southwestern Atlantic.

Indeed, results in Chapter 2, examining the outcome of competitive interactions between $T$. tagusensis and the endemic brain coral Mussismilia hispida, show consistent superiority of the invasive species in all tested scenarios. Nevertheless, both species growth rates were highly variable when in physical contact, demonstrating high response plasticity and thus the basis for selection of more tolerant phenotypes over generations upon frequent coexistence. Long-term adaptive evolution to a favorable phenotype (i.e. resistant to contact with heterospecific corals) is thus a relevant question. High proportion of clones with predominant asexual reproduction and lack of genetic structure along the invaded region (Capel et al. 2017) suggest low potential for genetically-based adaptation in sun corals. On the other hand, the pervasive effects caused by sun corals on $M$. hispida might select more resistant genotypes to competition, due to the strong genetic structure of this species (Peluso et al. 2018). This way, the scenario might be not that catastrophic to the endemic species in the long-term, but either way, our results still sustain the prediction that M. hispida will overall give substantial space to sun corals. 
Nonetheless, it is important to highlight the success on transplanting M. hispida colonies. Transplantation had no negative outcome on the colonies, that kept the same growth rates performed by the control ones. Being an important endemic scleractinian (Oigman-Pszczol \& Creed 2004), transplantation of brain coral colonies may be an interesting option when it comes to recover degraded reefs, since coral relocation has been established as an appropriate restoration technique (Rinkevich 2014, Rodgers et al. 2017). Another successful restoration method that could be used in Brazilian coral reefs is laboratory coral gardening (Rinkevich 1995, 2005), which, associated to colony fragmentation techniques may accelerate coral growth and make feasible restoration strategies at scale (Forsman et al. 2015). Also, it would be interesting to select colonies more resistant to thermal stress, naturally exposed to great temperature variation (Oliver \& Palumbi, 2011), or even acclimatize colonies in the laboratory before transplanting. This would allow the selection of the symbiont community of brain corals towards the dominance of the more thermally resistant types (Berkelmans \& van Oppen 2006).

In the present days, two of the most widespread global-change stressors to marine communities are warming and both the frequency and extent of species invasions (Kersting et al. 2015). Species can respond to climate warming in several ways; they can extend their range to new areas that become available within their thermal niche, they can acclimate and extend their in situ thermal niche, and they can experience range contractions where a modified climate exceeds their thermal niche, limiting persistence (Donelson et al. 2019). Successful invasive species are often generalists (Whitney \& Gabler 2008) and consequently better able to make use of novel resources into new habitats (Donelson et al. 2019). Overall, our results predict no great limitations for sun corals facing climate change. Their growth rates are the same during summer and winter, regardless of being in contact 
with a competitor or not, and their ability to impose damage to an endemic species was also not affected by temperature change, thus suggesting their competitive superiority towards native species will not be impaired by ocean warming. Temperature can affect the performance of pelagic stages of the sun coral Tubastraea tagusensis, creating delayed settlement competence windows at warmer temperatures, which would allow an escape response from habitats where larval mortality rates are high and favor large-scale dispersal to new regions. In conclusion, results suggest a worrying scenario, as long as warming of warm-temperate regions will favor further southward range expansions, along with the general trend of 'tropicalization' observed for several temperate marine ecosystems worldwide (Vergés et al. 2014). It is then urgent to improve and extend conservation policies and management strategies over the invasive range of sun-corals, if we aim to safeguard rocky-reef ecosystem services that have so far benefited coastal populations along the tropical and subtropical Southwestern Atlantic.

\section{REFERENCES}

Berkelmans Ray, van Oppen MJH (2006) The role of zooxanthellae in the thermal tolerance of corals: a 'nugget of hope' for coral reefs in an era of climate change. Proc R Soc Biol Sci 273 (1599): 2305-2312.

Bruno JF, Selig ER (2007) Regional Decline of Coral Cover in the Indo-Pacific: Timing, Extent, and Subregional Comparisons. PLoS ONE 2(8): e711.

Capel KCC, Toonen RJ, Rachid CTCC, Creed JC, Kitahara MV, Forsman Z, Zilberberg C (2017) Clone wars: asexual reproduction dominates in the invasive range of Tubastraea spp. (Anthozoa: Scleractinia) in the SouthAtlantic Ocean. PeerJ 5: e3873.

Castro CB, Pires DO (2001) Brazilian coral reefs: what we already know and what is still missing. Bull Mar Sci 69: 357-371.

Carothers JH, Jaksić FM (1984) Time as a Niche Difference: The Role of Interference Competition. Oikos 42 (3): 403-406.

Chesson P (2010) Mechanisms of maintenance of species diversity. Annu Rev Ecol Syst 31: 343-66.

Creed JC (2006) Two invasive alien azooxanthellate corals, Tubastraea coccinea and Tubastraea tagusensis, dominate the native zooxanthellate Mussismilia hispida in Brazil. Coral Reefs 25: 350. 
Creed JC, Paula AF (2007). Substratum preference during recruitment of two invasive recruitment of two invasive alien corals onto shallow-subtidal tropical rocky shores. Mar Ecol Progr Ser, 330: 101-111.

Creed JC, Fenner D, Sammarco PW, Cairns S, Capel KCC, Junqueira AOR, Cruz I, Miranda RJ, Carlos-Júnior LA, Mantelatto MC, Oigman-Pszczol SS (2016) The invasion of the azooxanthellate coral Tubastraea (Scleractinia: Dendrophylliidae) throughout the world: history, pathways and vectors. Biol Invasions 19: 283-305.

Da Silva AG, De Paula AF, Fleury BG, Creed JC (2014) Eleven years of range expansion of two invasive corals (Tubastraea coccinea and Tubastraea tagusensis) through the southwest Atlantic (Brazil). Estuarine, Coastal and Shelf Science 141: 9-16.

De Paula AF, Creed JC (2005). Spatial distribution and abundance of non-indigenous coral genus Tubastraea (Cnidaria, Scleractinia) around Ilha Grande, Brazil. Brazil Journal Biology, 65: 661-673.

De Paula AF, Pires DO, Creed JC (2014) Reproductive strategies of two invasive sun corals (Tubastraea spp.) in the southwestern Atlantic. J Mar Biol Assoc UK 94 (3): 481-492.

Dos Santos LAH, Ribeiro FV, Creed JC (2013) Antagonism between invasive pest corals Tubastraea spp. and the native reef-builder Mussismilia hispida in the southwest Atlantic. J Exp Mar Biol Ecol 449: 69-76.

Donelson JM, Sunday JM, Figueira WF, Gaitán-Espitia JD, Hobday AJ, Johnson CR, Leis JM, Ling SD, Marshall D, Pandolfi JM, Pecl G, Rodgers GG, Booth DJ, Munday PL (2019) Understanding interactions between plasticity, adaptation and range shifts in response to marine environmental change. Phil Trans $R$ Soc $B$ 374: 20180186.

Forsman ZH, Page CA, Toonen RJ, Vaughan D (2015), Growing coral larger and faster: micro-colony-fusion as a strategy for accelerating coral cover. PeerJ 3: e1313.

Glynn PW, Colley SB, Maté JL, Cortés J, Guzman HM, Bailey RL, Feingold JS, Enochs IC (2008) Reproductive ecology of the azooxanthellate coral Tubastraea coccinea in the Equatorial Eastern Pacific: Part V. Dentrophylliidae. Mar Biol 153: 529-544.

Grillo AC, Bonaldo RM, Segal B (2017) Physical contact interactions with scleractinian corals in hard substrate communities. Mar Ecol 39: e12482.

Hennessey SM, Sammarco PW (2014) Competition for space in two invasive Indo-Pacific corals - Tubastraea micranthus and Tubastraea coccinea: Laboratory experimentation. J Exp Mar Biol Ecol 459: 144-150.

Hughes TP, Baird AH, Dinsdale EA, Moltschaniwskyj NA, Pratchett MS, Tanner JE, Willis BL (2000) Supply-side ecology works both ways: the link between Benthic adults, fecundity, and larval recruits. Ecology 81 (8): 2241-2249.

Kahng S, Wagner D, Lantz C, Vetter O, Gove J, Merrifield M (2012) Temperature related depth limits of warmwater corals. Proceedings of the 12th International Coral Reef Symposium, Ecology of mesophotic coral reefs.

Kersting DK, Cebrian E, Casado C, Teixidó N, Garrabou J, Linares C (2015). Experimental evidence of the synergistic effects of warming and invasive algae on a temperate reef builder coral. Scientific Reports, 5: 18635.

Keane RM, Crawley MJ (2002) Exotic plant invasions and the enemy release hypothesis. Trends in Ecology \& Evolution 17 (4): 164-170.

Lages BG, Fleury BG, Pinto AC, Creed JC (2010) Chemical defenses against generalist fish predators and fouling organisms in two invasive ahermatypic corals in the genus Tubastraea. Mar Ecol 31: 473-482.

Lages BG, Fleury BG, Menegola C, Creed JC (2011) Change in tropical rocky shore communities due to an alien coral invasion. Mar Ecol Prog Ser 438: 85-96. 
Lubchenco J (1980) Algal zonation in the New England rocky intertidal community - an experimental analysis. Ecology 61: 333-344.

Luz BPL, Kitahara MV (2017) Could the invasive scleractinians Tubastraea coccinea and T. tagusensis replace the dominant zoantharian Palythoa caribaeorum in the Brazilian subtidal? Coral Reefs 36: 875.

Luz BLP, Capel KCC, Zilberberg C, Flores AAV, Migotto AE, Kitahara MV (2018) A polyp from nothing: The extreme regeneration capacity of the Atlantic invasive sun corals Tubastraea coccinea and $T$. tagusensis (Anthozoa, Scleractinia) J Exp Mar Biol Ecol 503: 60-65.

Menge BA (1976) Organization of the New England rocky intertidal community: role of predation, competition, and environmental heterogeneity. Ecol Monogr 46: 355-393.

Menge BA, Sutherland JP (1976) Species Diversity Gradients: Synthesis of the Roles of Predation, Competition, and Temporal Heterogeneity. Am Natur 110 (973): 351-369.

Mizrahi D, Navarrete SA, Flores AAV (2014) Groups travel further: pelagic metamorphosis and polyp clustering allow higher dispersal potential in sun coral propagules. Coral Reefs 33: 443-448.

Mizrahi D, Kitahara MV, Barbosa ACC, Flores AAV (2016) Possible interference competition involving established fish and a sun coral incursion. Mar Biodiv 47 (2): 369-370.

Moreira TSG, Creed JC (2012) Invasive, non-indigenous corals in a tropical rocky shore environment: No evidence for generalist predation. J Exper Mar Biol Ecol 438:7-13.

Oigman-Pszczol SS, Figueiredo MAO, Creed JC (2004) Distribution of Benthic Communities on the Tropical Rocky Subtidal of Armação dos Búzios, Southeastern Brazil. Mar Ecol 25 (3): 173-190.

Oliver TA, Palumbi SR (2011) Do fluctuating temperature environments elevate coral thermal tolerance? Coral Reefs 30: 429-440.

Peluso L, Tascheri V, Nunes FLD, Castro CB, Pires DO, Zilberberg C (2018) Contemporary and historical oceanographic processes explain genetic connectivity in a Southwestern Atlantic coral. Sci Rep 8: 2684.

Rinkevich B (1995) Restoration Strategies for Coral Reefs Damaged by Recreational Activities: The Use of Sexual and Asexual Recruits. Restor Ecol 3 (4): 241:251.

Rinkevich B (2005) Conservation of Coral Reefs through Active Restoration Measures: Recent Approaches and Last Decade Progress. Environ Sci Technol 39: 4333-4342.

Rinkevich B (2014) Rebuilding coral reefs: does active reef restoration lead to sustainable reefs? Curr Opin Environ Sustain 7:28-36.

Roberts CM, McClean CJ, Veron JEN, Hawkins JP, Allen GR, McAllister DE, Mittermeier CG, Schueler FW, Spalding M, Wells F, Vynne C, Werner TB (2002) Marine Biodiversity Hotspots and Conservation Priorities for Tropical Reefs. Science 295 (5558): 1280-1284.

Rodgers KS, Lorance K, Donà AR, Stender Y, Lager C, Jokiel PL (2017) Effectiveness of coral relocation as a mitigation strategy in Kane'ohe Bay, Hawai'i. PeerJ 5: e3346.

Sammarco PW, Porter SA, Genazzio M, Sinclair J (2015) Success in Competition for Space in Two Invasive Coral Species in the western Atlantic - Tubastraea micranthus and T. coccinea. PLoS ONE 10(12): e0144581.

Sheppard CRC (1982) Coral Populations on Reef Slopes and Their Major Controls. Mar Ecol Prog Ser 7: 83115.

Shinen JL, Navarrete SA. (2010) Coexistence and intertidal zonation of chthamalid barnacles along central Chile: Interference competition or a lottery for space? J Exp Mar Bio Ecol 392: 176-187. 
Shinen JL, Navarrete SA. (2014) Lottery Coexistence on Rocky Shores: Weak Niche Differentiation or Equal Competitors Engaged in Neutral Dynamics? Am Nat 183: 342-362.

Silva R, Vinagre C, Kitahara MV, Acorsi I, Mizrahi D, Flores AAV (2019) Sun coral invasion of shallow rocky reefs: effects on mobile invertebrate assemblages in Southeastern Brazil. Biol Invasions 21 (4): 13391350.

Soares MO, Davis M, Carneiro PBM (2018) Northward range expansion of the invasive coral (Tubastraea tagusensis) in the southwestern Atlantic. Mar Biodiv 48: 1651-1654.

Underwood AJ, Fairweather PG (1989) Supply-side Ecology and Benthic Marine Assemblages. Trends Ecol Evol 4 (1): 16-20.

Vergés A, Steinberg PD, Hay ME, Poore AGB, Campbell AH, Ballesteros E, Heck Jr KL, Booth DJ, Coleman MA, Feary DA, Figueira W, Langlois T, Marzinelli EM, Mizerek T, Mumby PJ, Nakamura Y, Roughan M, van Sebille E, Gupta AS, Smale DA, Tomas F, Wernberg T, Wilson SK (2017) The tropicalization of temperate marine ecosystems: climate-mediated changes in herbivory and community phase shifts. Proc R Soc $B$ 281: 20140846.

Vermeij, MJA (2006) Early life-history dynamics of Caribbean coral species on artificial substratum: the importance of competition, growth and variation in life-history strategy. Coral Reefs 25: 59-71.

Vieira EA, Flores AAV, Dias GM (2018a) Persistence and space preemption explain species-specific founder effects on the organization of marine sessile communities. Ecol Evol 8: 3430-3442.

Vieira EA, Flores AAV, Dias GM (2018b) Adding early-stage engineering species affects advanced stage organization of shallow-water fouling assemblages. Hydrobiol 818: 211-222.

Whitney KD, Gabler CA (2008) Rapid evolution in introduced species, 'invasive traits' and recipient communities: challenges for predicting invasive potential. Divers Distrib 14 